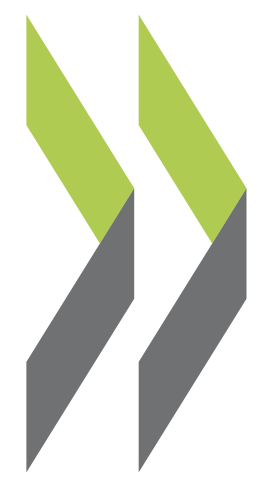

OECD Economics Department Working Papers No. 1519

Increasing inclusiveness for women, youth Andrew Barker and seniors in Canada 


\section{INCREASING INCLUSIVENESS FOR WOMEN, YOUTH AND SENIORS IN} CANADA

\section{ECONOMICS DEPARTMENT WORKING PAPERS No. 1519}

\section{By Andrew Barker}

OECD Working Papers should not be reported as representing the official views of the OECD or of its member countries. The opinions expressed and arguments employed are those of the author(s)

Authorised for publication by Álvaro Pereira, Director, Country Studies Branch, Economics Department.

All Economics Department Working Papers are available at www.oecd.org/eco/workingpapers

JT03440976 
ECO Working Papers should not be reported as representing the official views of the OECD or of its member countries. The opinions expressed and arguments employed are those of the author(s).

Working Papers describe preliminary results or research in progress by the author(s) and are published to stimulate discussion on a broad range of issues on which the OECD works.

Comments on Working Papers are welcomed, and may be sent to OECD Economics Department, 2 rue AndréPascal, 75775 Paris Cedex 16, France, or by e-mail to eco.contact@oecd.org.

All Economics Department Working Papers are available at www.oecd.org/eco/workingpapers.

This document and any map included herein are without prejudice to the status of or sovereignty over any territory, to the delimitation of international frontiers and boundaries and to the name of any territory, city or area.

The statistical data for Israel are supplied by and under the responsibility of the relevant Israeli authorities. The use of such data by the OECD is without prejudice to the status of the Golan Heights, East Jerusalem and Israeli settlements in the West Bank under the terms of international law.

Latvia was not an OECD Member at the time of preparation of this publication. Accordingly, Latvia does not appear in the list of OECD Members and is not included in the zone aggregates.

On 3 May 2018, the OECD Council invited Lithuania to become a Member. At the time of preparation the deposit of Lithuania's instrument of accession to the OECD Convention was pending and therefore Lithuania does not appear in the list of OECD Members and is not included in the OECD zone aggregates.

On 25 May 2018, the OECD Council invited Colombia to become a Member. At the time of preparation the deposit of Colombia's instrument of accession to the OECD Convention was pending and therefore Colombia does not appear in the list of OECD Members and is not included in the OECD zone aggregates.

\section{(c) OECD (2018)}

You can copy, download or print OECD content for your own use, and you can include excerpts from OECD publications, databases and multimedia products in your own documents, presentations, blogs, websites and teaching materials, provided that suitable acknowledgment of OECD as source and copyright owner is given. All requests for commercial use and translation rights should be submitted to rights@oecd.org 


\section{ABSTRACT/RÉSUMÉ \\ Increasing inclusiveness for women, youth and seniors in Canada}

Women, youth and seniors face barriers to economic inclusion in Canada, with considerable scope to improve their labour market outcomes. There has been no progress in shrinking the gender employment gap since 2009, and women, particularly mothers, continue to earn significantly less than men, in part due to a large gap in unpaid childcare responsibilities. Outside the province of Québec, low (but increasing) rates of government support for childcare should be expanded considerably, as should fathers' low take-up of parental leave. Skills development should be prioritised to arrest declining skills among youth and weak wage growth among young males with low educational attainment. Fragmented labour market information needs to be consolidated to address wage penalties associated with the widespread prevalence of qualifications mismatch. Growth in old-age poverty should be tackled through further increases in basic pension payments over time. Linking changes in the age of eligibility for public pensions to life expectancy would boost growth by increasing employment of older Canadians still willing and able to work. For all three groups, well-targeted expansions of in-work tax benefits and active labour market spending have the potential to increase employment.

JEL Classification: H55, I38, J26, J40.

Keywords: inclusiveness, labour force participation, employment, child care, parental leave, gender equality, apprenticeship, life-long learning, labour market participation of seniors, pensions, longterm care, Canada.

\section{Améliorer l'insertion des femmes, des jeunes et des seniors au Canada}

Au Canada, l'inclusion économique des femmes, des jeunes et des personnes âgées se heurte à des obstacles, et leur participation au marché du travail pourrait être considérablement améliorée. La réduction des inégalités femmes-hommes face à l'emploi stagne depuis 2009 et les femmes, notamment les mères, continuent de gagner sensiblement moins que les hommes, en partie à cause de l'importante disparité du partage des responsabilités non rémunérées relatives à la garde d'enfants. Ailleurs que dans la province du Québec, les montants de l'aide publique à la garde d'enfants, faibles quoi qu'en hausse, devraient être nettement augmentés, et il conviendrait aussi que soient développés les congés parentaux des pères, actuellement peu utilisés. Il faudrait en outre donner la priorité au développement des compétences pour endiguer le déclin des qualifications observé chez les jeunes et mettre fin à l'atonie de la croissance des salaires parmi les hommes jeunes ayant un faible niveau d'éducation. Il faut aussi regrouper les informations sur le marché de l'emploi, actuellement dispersées, pour répondre au déséquilibre entre l'offre et la demande de compétences et aux désavantages salariaux qui en découlent. Il faut réagir à l'augmentation de la pauvreté chez les personnes âgées en relevant progressivement le montant des pensions de base. Lier l'évolution de l'âge de l'ouverture des droits à la retraite publique à celle de l'espérance de vie favoriserait la croissance en développant l'emploi des Canadiens du troisième âge qui souhaitent continuer à travailler et ont la possibilité de le faire. Pour ces trois groupes, une hausse soigneusement ciblée des prestations liées au travail et des dépenses consacrées à des mesures actives du marché du travail est susceptible d'accroître l'emploi.

Classification JEL : H55, I38, J26, J40,

Mots clefs: insertion, participation de la main-d'œuvre, emploi, garde des enfants, congé parental, égalité des sexes, apprentissages, apprentissage tout au long de la vie, participation des seniors au marché du travail, pensions, soins à long terme, Canada 


\section{Table of contents}

Increasing inclusiveness for women, youth and seniors in Canada ............................................... 6

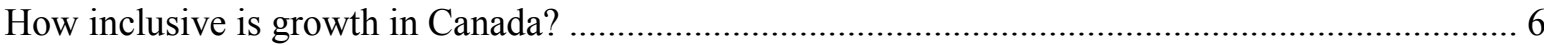

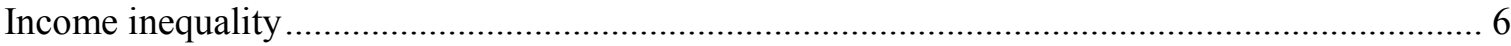

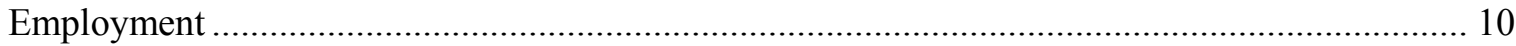

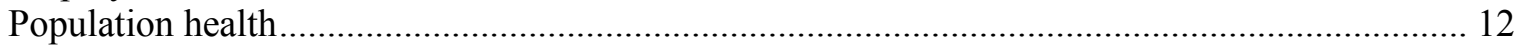

Labour market policy issues relevant for women, youth and seniors ……..................................... 13

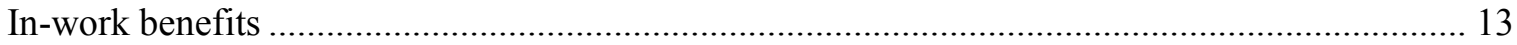

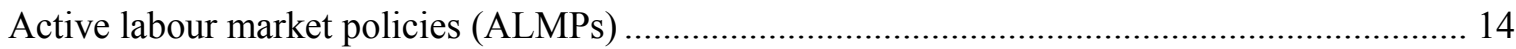

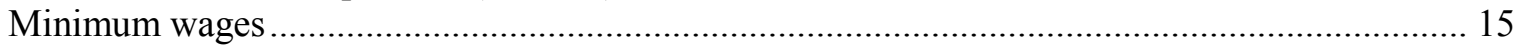

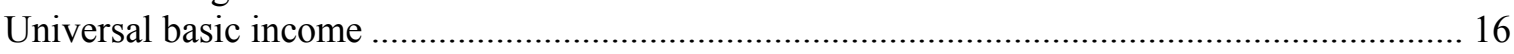

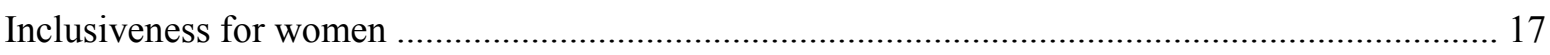

Gender gaps in wages and employment reduce female incomes ............................................ 17

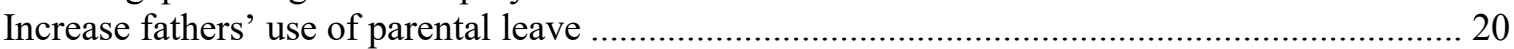

Increase the availability and affordability of high-quality early childhood education and care

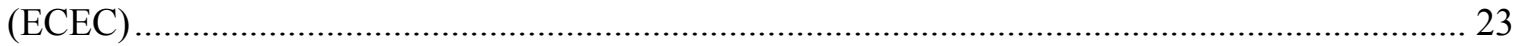

Remove barriers to women's participation in computing and engineering................................... 28

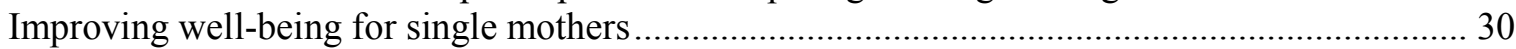

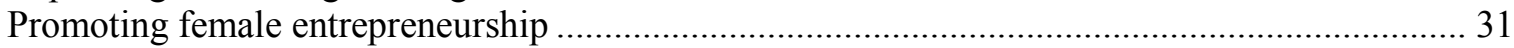

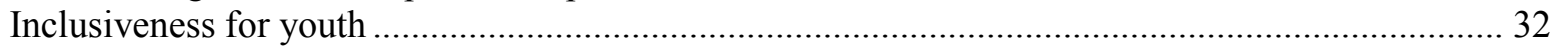

A substantial minority of Canadian youth are at risk of becoming detached from the labour

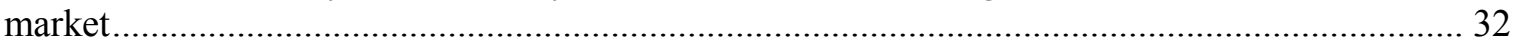

Earnings for most young men are yet to recover from earlier declines........................................... 33

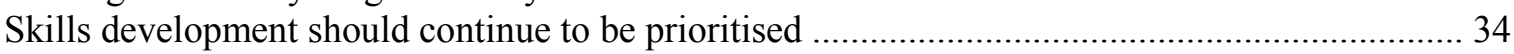

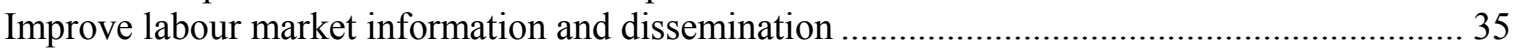

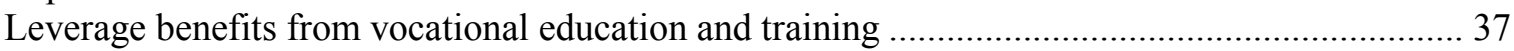

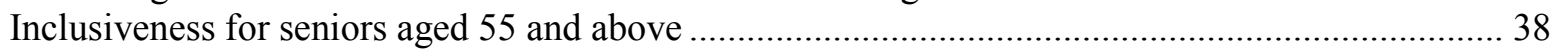

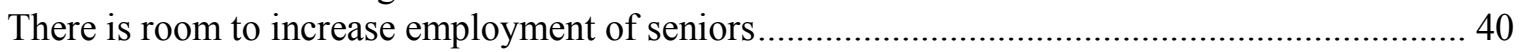

Reduce marginal effective tax rates for people eligible for GIS payments .................................... 41

Increase the normal retirement age in line with life expectancy ....................................................... 43

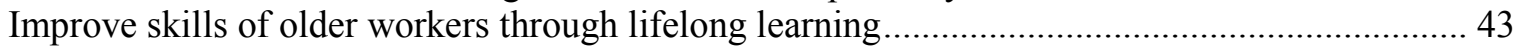

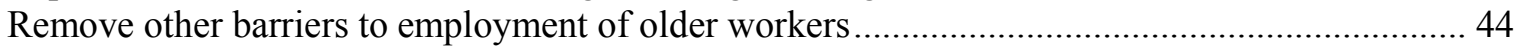

Curb old-age poverty through further real increases in public pensions ......................................... 45

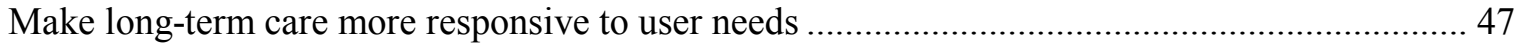

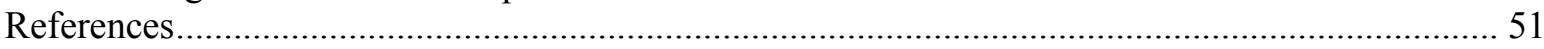

\section{Tables}

Table 1. Scheduled minimum wage increases vary considerably across provinces ............................ 16

Table 2. Recent provincial initiatives to improve early childhood education and care ......................... 25

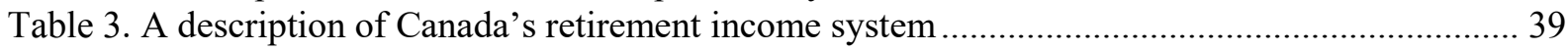

Table 4. Options to introduce more generous indexation of public pensions ........................................ 46

\section{Figures}


Figure 1. Canada's income distribution is near average, but redistribution is modest ........................... 7

Figure 2. Canada's relative poverty rate after taxes and transfers is also middling .............................. 7

Figure 3. Canada performs extremely well on intergenerational income mobility ${ }^{1}$............................... 8

Figure 4. Many students from disadvantaged backgrounds perform well ............................................ 9

Figure 5. Regional disparities in household disposable income are high and increasing....................... 9

Figure 6. Median per capita after-tax income by Aboriginal identity ................................................ 10

Figure 7. Employment rates for 15-64 year-olds are high but growing only slowly............................ 10

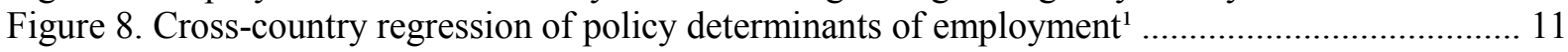

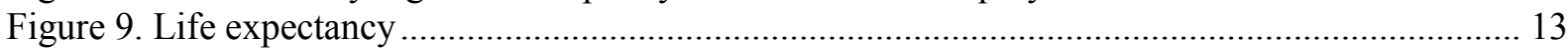

Figure 10. Spending on active labour market programmes per unemployed person is $\operatorname{low}^{1} \ldots \ldots \ldots \ldots \ldots \ldots . . . .15$

Figure 11. Labour market gender gaps are relatively small but no longer shrinking ........................... 18

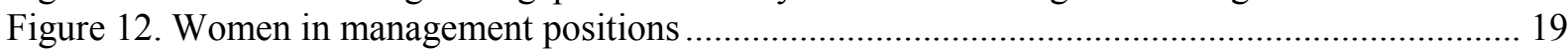

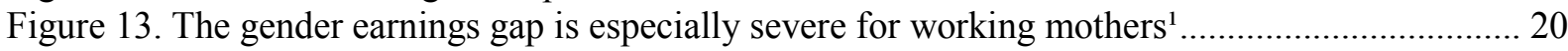

Figure 14. Canadian men spend less time on childcare activities than their female spouses ${ }^{1}$............... 20

Figure 15. Paid leave entitlements for mothers are near the OECD average ..................................... 21

Figure 16. The net cost of childcare ${ }^{1}$ for a couple family in 2015 was relatively high ........................ 24

Figure 17. Few Canadian children attended early childhood education for two years or more ............ 27

Figure 18. Canada's gender equality position in $\mathrm{STEM}^{1}$ bachelor degree's graduates is mixed .......... 29

Figure 19. Poverty rates of employed and unemployed single-parent families are high...................... 31

Figure 20. Slightly fewer youth than average are not in employment, education or training ............... 33

Figure 21. Youth unemployment is high for those who do not complete high school .......................... 33

Figure 22. Skills gaps between those with and without tertiary education are large............................. 34

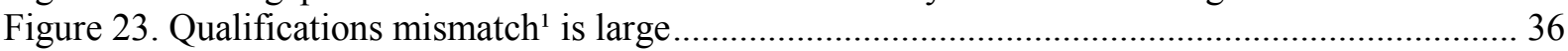

Figure 24. Canada's relative poverty rate after taxes and transfers is low for the over- $65 \mathrm{~s}^{1} \ldots \ldots \ldots \ldots . . . . .39$

Figure 25. Employment rates of 55 to 64 year-olds were slightly above the OECD average in 2016.. 40

Figure 26. The age distribution of retirement was concentrated around 60 and 65 in 2014 ............... 41

Figure 27. Incentives to remain in the workforce beyond 55 and 60 vary by age group .................... 42

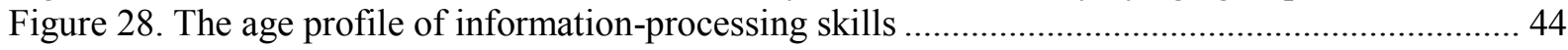

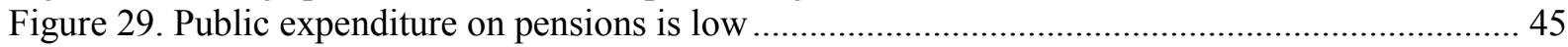

\section{Boxes}

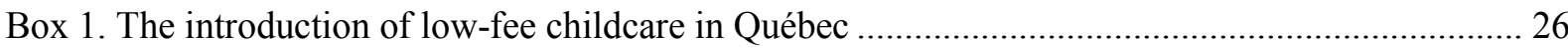




\title{
Increasing inclusiveness for women, youth and seniors in Canada
}

\author{
By Andrew Barker ${ }^{1}$
}

Inclusive growth is economic growth that creates opportunities for all segments of the population and distributes the dividends of increased prosperity, both in monetary and nonmonetary terms, fairly across society. Inequality of opportunity undermines growth prospects in the long term and the ability of countries to meet the expectations of their residents, with the potential to derail support for policies that offer the potential for faster economic growth. Inclusive growth is particularly important in high-income countries today, as income inequality has reached levels unprecedented in the post-war period. In several policy areas there are opportunities for "win-win policies" that deliver improved inclusiveness as well as productivity growth (OECD, 2016 $\left.6_{[1]}\right)$.

Canada's income inequality is close to the OECD average, and its intergenerational income mobility is high. However, some groups within Canada do not fare so well and the relative poverty rate is above the OECD average. This paper focuses on opportunities to improve outcomes for three groups that face barriers to social and economic inclusion: women, youth and Canadians aged 55 and above ("seniors"). Socio-economic outcomes for Indigenous populations are also worse on average than for other Canadians on a number of measures, and some immigrants never overcome their disadvantages relative to the Canadian-born population.

\section{How inclusive is growth in Canada?}

Canada scores highly in all dimensions of the OECD's Better Life Index (OECD, 2017 ${ }_{[2]}$ ), but this does not mean that all Canadians experience high well-being. A more granular assessment shows that there is considerable scope to improve employment outcomes and incomes for women, youth and older Canadians, which motivates the focus on labour market inclusiveness in the paper. The comparisons in this section are based on a multidimensional assessment of inclusiveness that encompasses incomes, jobs and health, following the OECD framework for inclusive growth (OECD, 2014 $\left.{ }_{[3]}\right)$.

\section{Income inequality}

Income inequality in Canada has changed little during the 2000s and is close to the OECD average, reflecting relatively low inequality in gross incomes (Figure 1). Relative poverty rates also fall in the middle of the range for OECD countries and have edged up slightly since the mid-1990s (Figure 2). The reduction in income inequality through taxes (broadly defined) and transfers is less than the OECD average, primarily due to the small size of cash transfers (Causa and Hermansen, 2017 ${ }_{[4]}$ ). Personal income taxes achieve a similar degree of redistribution to the OECD average, while social security contributions are regressive (abstracting from their key role in financing redistributive transfers), because the

\footnotetext{
${ }^{1}$ Andrew Barker is an Economist in the Country Studies Branch of the Economics Department of the OECD; email: andrew.barker@oecd.org. This paper was prepared for the OECD Economic Survey of Canada published in July 2018 under the authority of the Economic and Development Review committee. The author would like to thank Alberto Pandiella, Peter Jarrett, Willem Adema, Andrea Bassanini, Herwig Immervol, Sarah Strapps, Michela Meghnagi, Jonathan Barr, David Carey, Isabelle Koske, Alvaro Pereira and Canadian government officials for their valuable comments and suggestions. Special thanks are due to Isabelle Luong for excellent statistical assistance and to Heloise Wickramanayake for excellent technical preparation.
} 
low cap means these take a larger share of income for low-income earners. Canadian cash transfers are more targeted to low-income households than the OECD average, but less so than in several countries with similar political systems, notably New Zealand, Australia and the United Kingdom (Causa and Hermansen, 2017 ${ }_{[4]}$ ). Overall, modest redistribution through taxes and transfers heightens the importance of better targeting of inclusiveness policies for women, youth and seniors, which the recommendations in this paper seek to achieve.

Figure 1. Canada's income distribution is near average, but redistribution is modest Gini coefficients for the working-age population, scale from 0 (perfect equality) to 1 (perfect inequality), 2016 or latest available year ${ }^{1}$

0.7

$\nabla \quad$ Before taxes and transfers

0.6

- After taxes and transfers

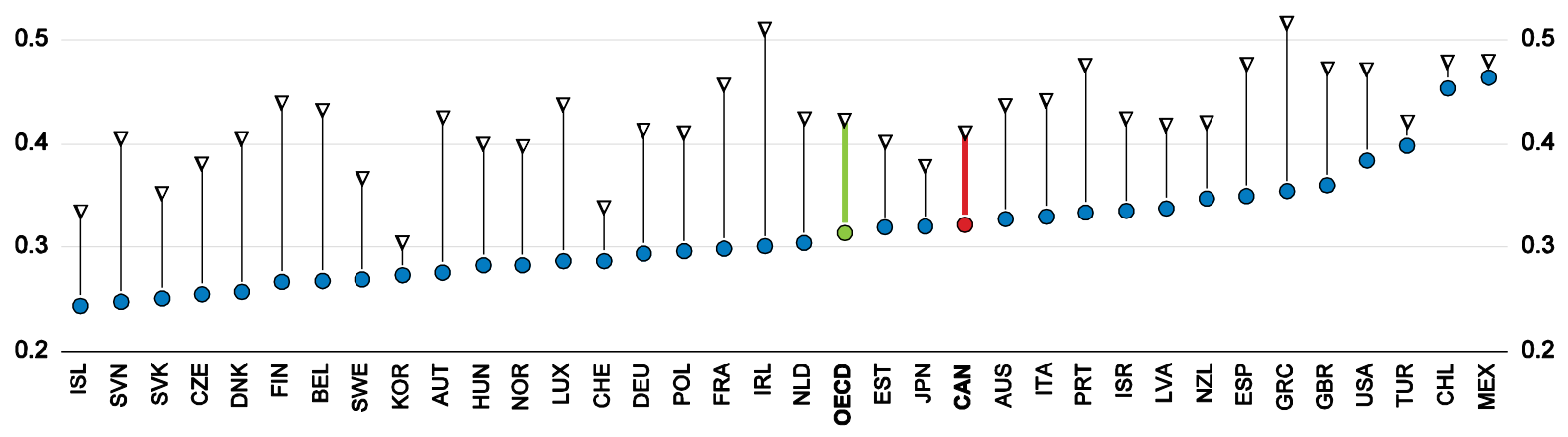

1. 2014 data for the OECD aggregate.

Source: OECD, Income Distribution database, http://www.oecd.org/els/soc/income-distribution-database.htm.

Figure 2. Canada's relative poverty rate after taxes and transfers is also middling

Poverty line at $50 \%$ of median disposable income ${ }^{1}$

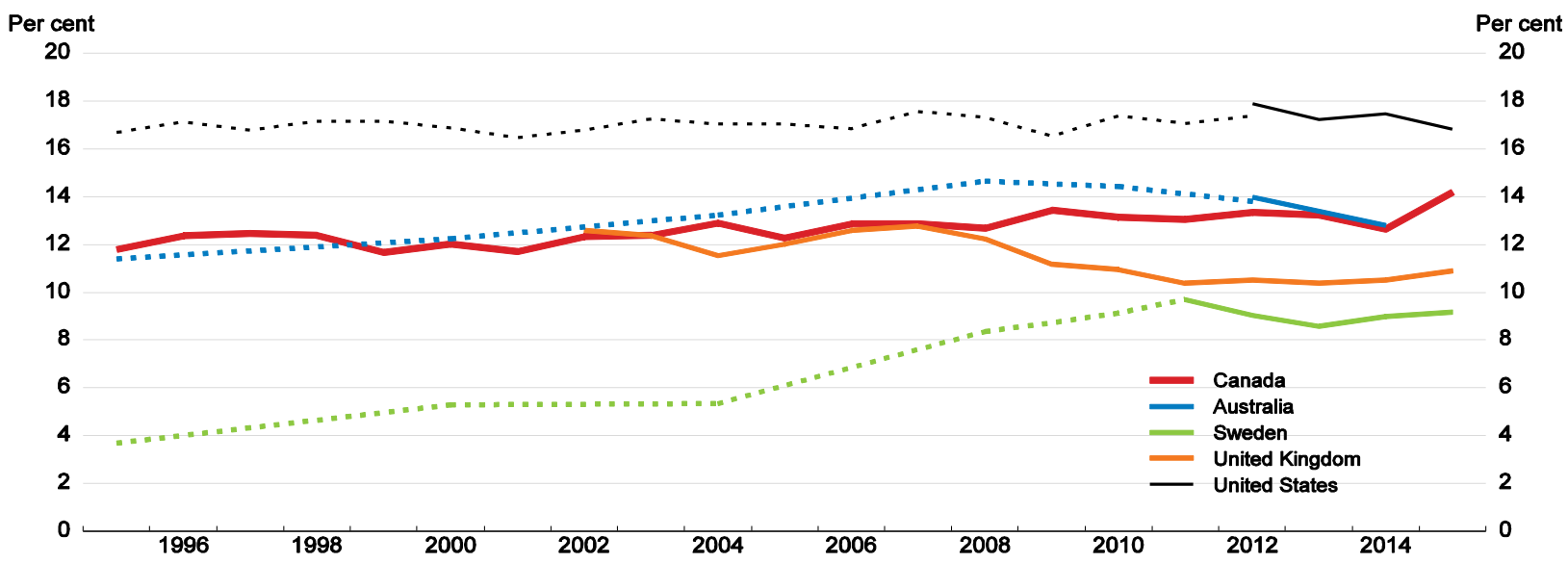

1. Dotted lines are data under the old, pre-2012 income definition. The OECD average is not available due to series breaks between old and new income definitions, which are inconsistent across countries.

Source: OECD (2017), Income Distribution database, http://www.oecd.org/els/soc/income-distributiondatabase.htm. 
Canada is, however, a strong performer on intergenerational mobility, which is critical to ensure that all socio-economic groups can access opportunities from economic growth, to make the most of the capabilities of all Canadians and to avoid the creation of poverty traps. Intergenerational income mobility is particularly high given mid-range aggregate income inequality (Figure 3). Intergenerational mobility is also strong when measured in terms of the share of top-performing students from disadvantaged backgrounds, which approaches outcomes from several of the OECD's best-performing education systems (Figure 4). Canada is one of just eight OECD countries that perform above the OECD average in at least 9 out of 11 outcome indicators relating to equality of opportunities in education (OECD, 2017[5]).

Figure 3. Canada performs extremely well on intergenerational income mobility ${ }^{1}$

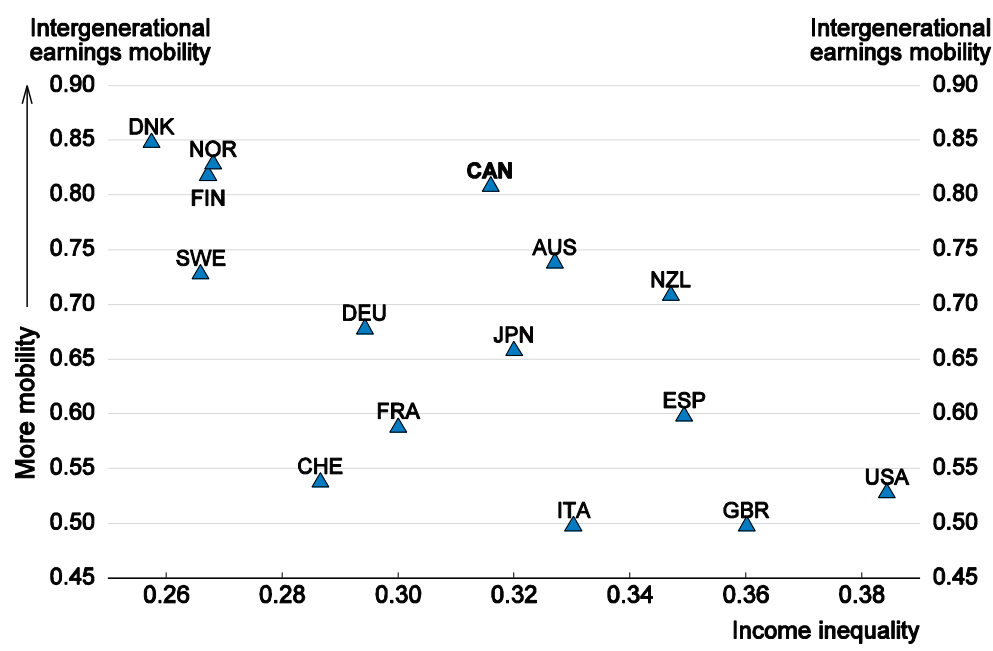

1. Income inequality is measured by the Gini coefficient for household disposable income of the working-age population in the mid-2010s. Intergenerational earnings mobility is measured as one minus the elasticity between paternal earnings and a son's adult earnings, using data on a cohort of children born, roughly speaking, during the early- to mid-1960s and measuring their adult outcomes in the mid- to late-1990s. See Corak (2006) for more details.

Source: OECD, Income Distribution database; M. Corak (2013), "Inequality from Generation to Generation: the United States in Comparison", Chap. 6 in R. Rycroft (ed.), The Economics of Inequality, Poverty and Discrimination in the 21st Century, ABC-CLIO, Santa Barbara, CA; M. Corak (2006), "Do Poor Children Become Poor Adults? Lessons for Public Policy from a Cross-Country Comparison of Generational Earnings Mobility", Research on Economic Inequality, Vol. 13, pp. 143-188.

Some groups in Canada do not fare as well on measures of inclusiveness. Regional disparities in household disposable income are high by OECD standards and have increased since the mid-1990s as incomes in resource-rich provinces have moved further ahead (Figure 5). Of greater importance for inclusiveness, median incomes for Indigenous Canadians are below those of the non-Indigenous population (by more than $30 \%$ for the First Nations population) (Figure 6). A wide range of Canadians, particularly youth, are adversely affected by rapid increases in housing prices in major centres. This decreases disposable incomes of those who have recently purchase houses and those affected by high rents, which have increased by $8 \%$ in real terms over the past decade $\left(\mathrm{CMHC}, 2017_{[6]}\right)$. 
Figure 4. Many students from disadvantaged backgrounds perform well

Percentage of top-performing students with a low socio-economic background ${ }^{1}$

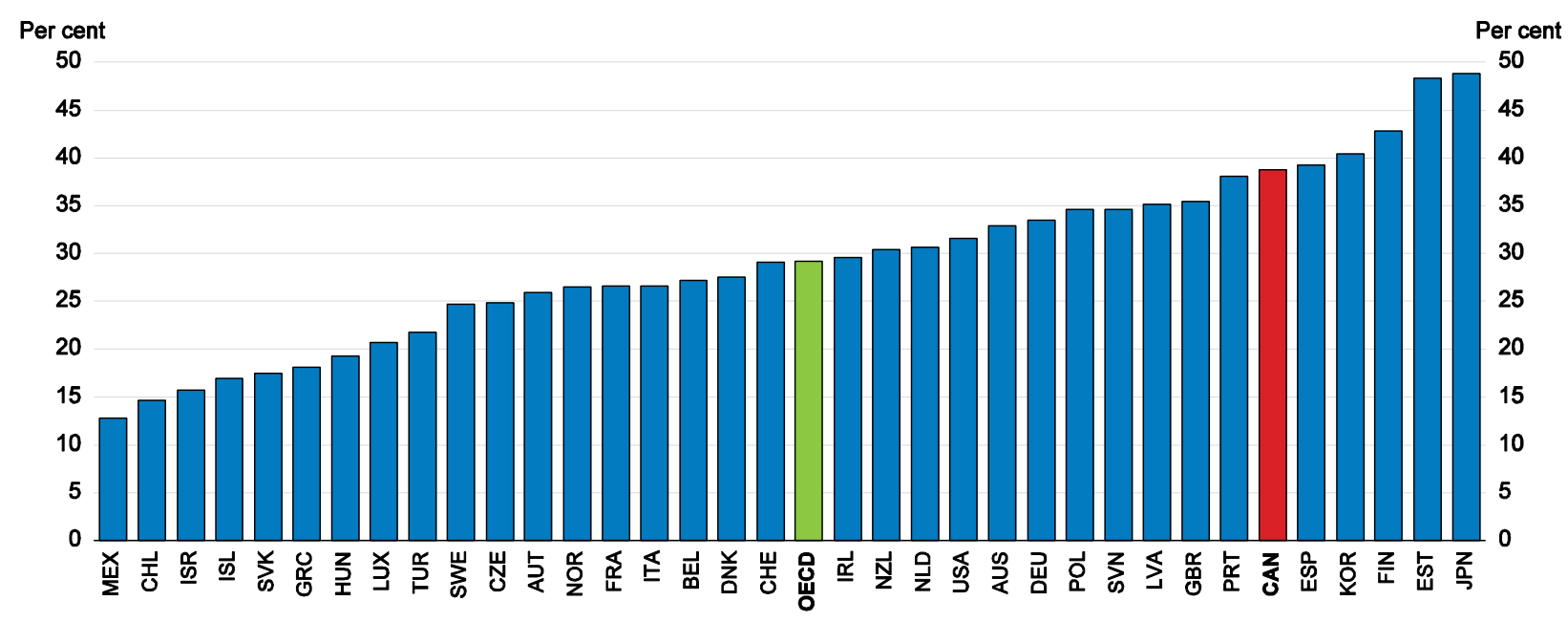

1. Students in the bottom quarter of the PISA index of economic, social and cultural status (ESCS) in the country/economy of assessment and performing in the top quarter of students among all countries/economies, after accounting for differences in socio-economic status across countries.

Source: OECD (2016), PISA 2015 Results (Volume I): Excellence and Equity in Education, Table I.6.7.

Figure 5. Regional disparities in household disposable income are high and increasing Coefficient of variation of regional disposable income

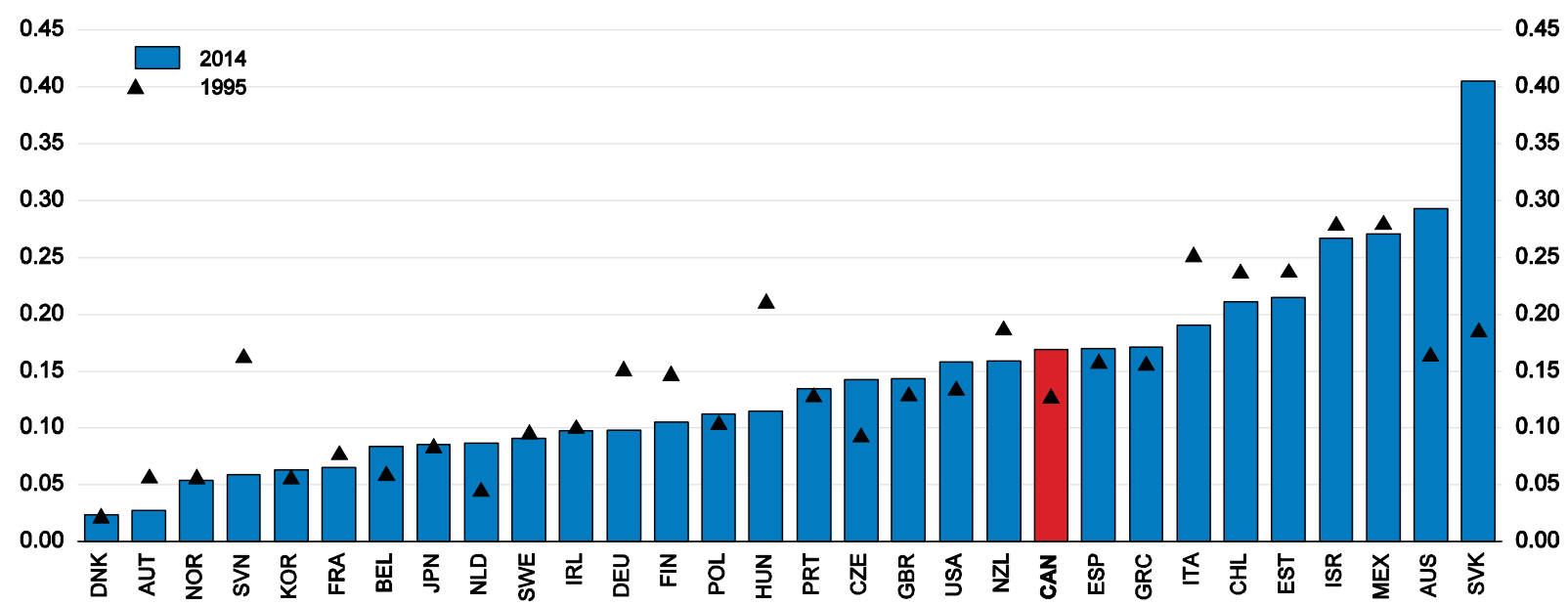

Source: OECD (2016), OECD Regions at a Glance 2016, Figure 1.5. 
Figure 6. Median per capita after-tax income by Aboriginal identity Population aged 15 years and older, 2016

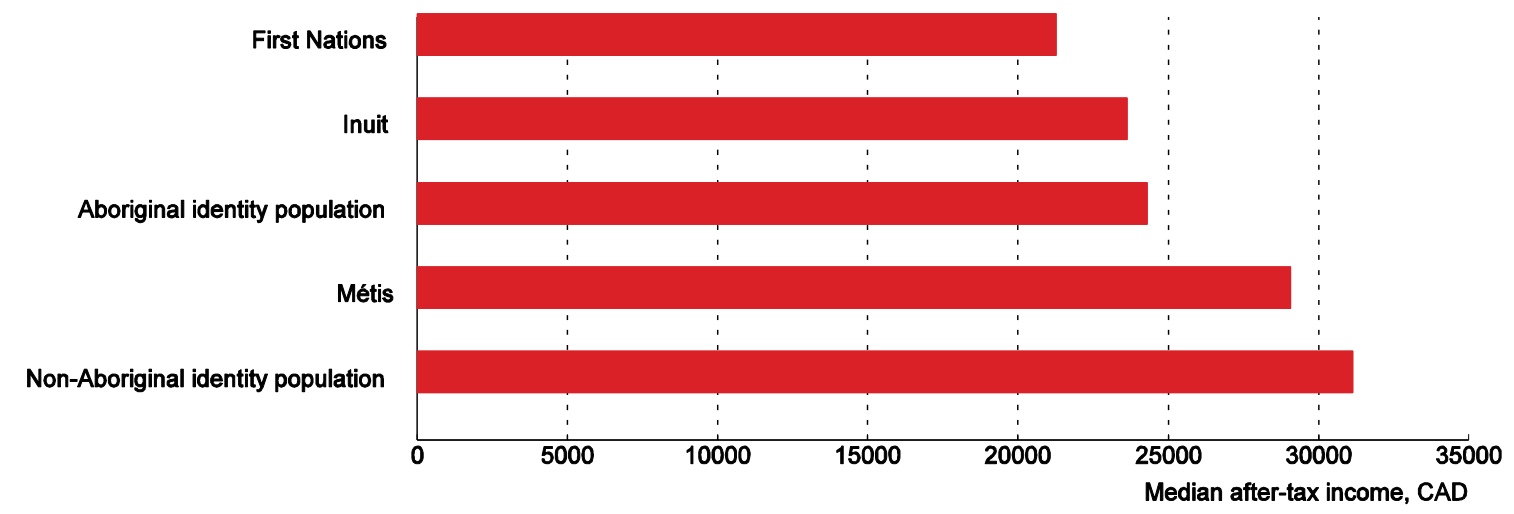

Source: Statistics Canada, 2016 Census, Catalogue Number 98-400-X2016170.

\section{Employment}

There is considerable room to improve employment rates in Canada, including among women, youth and older Canadians. For the working-age population, employment rates exceed the OECD average but have seen little increase since the years prior to the crisis and have fallen further behind leading OECD countries such as Sweden (Figure 7). Results from panel regressions applying the methodological approach of Bassanini and Duval $\left(2006_{[7]}\right)$ indicate scope to increase employment for all three groups that are the focus of this paper by improving policy settings to match those of leading OECD countries (Figure 8). Potential benefits are greatest for women, associated with increasing public expenditure on early childhood education and care (ECEC) and active labour market programmes (ALMPs). Increased spending on ALMPs, and tailoring them to the needs of youth and seniors, also has the potential to boost employment among these groups, while increases in the normal retirement age could raise employment among older Canadians and also deliver budgetary savings. Policy recommendations made in this

Figure 7. Employment rates for 15-64 year-olds are high but growing only slowly

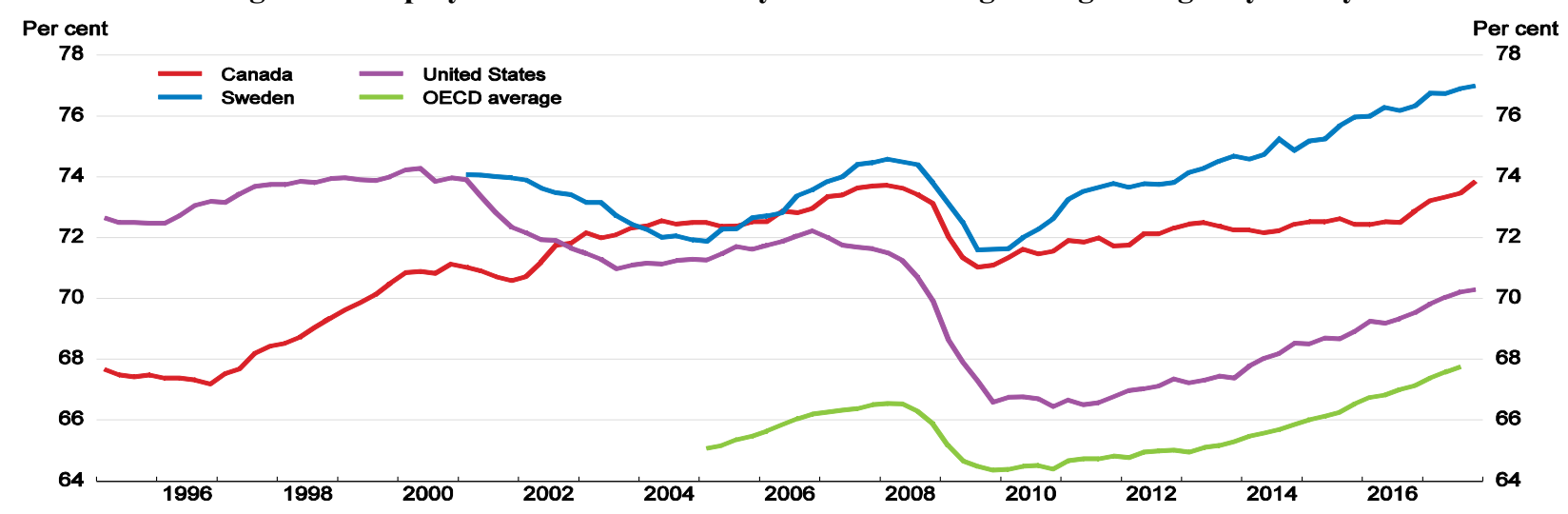

Source: OECD, Short-Term Labour Market Statistics database. 
Figure 8. Cross-country regression of policy determinants of employment ${ }^{1}$

\section{A. Increase In group-speclflc employment from an addltlonal $0.1 \%$ GDP expendlture In Canada}

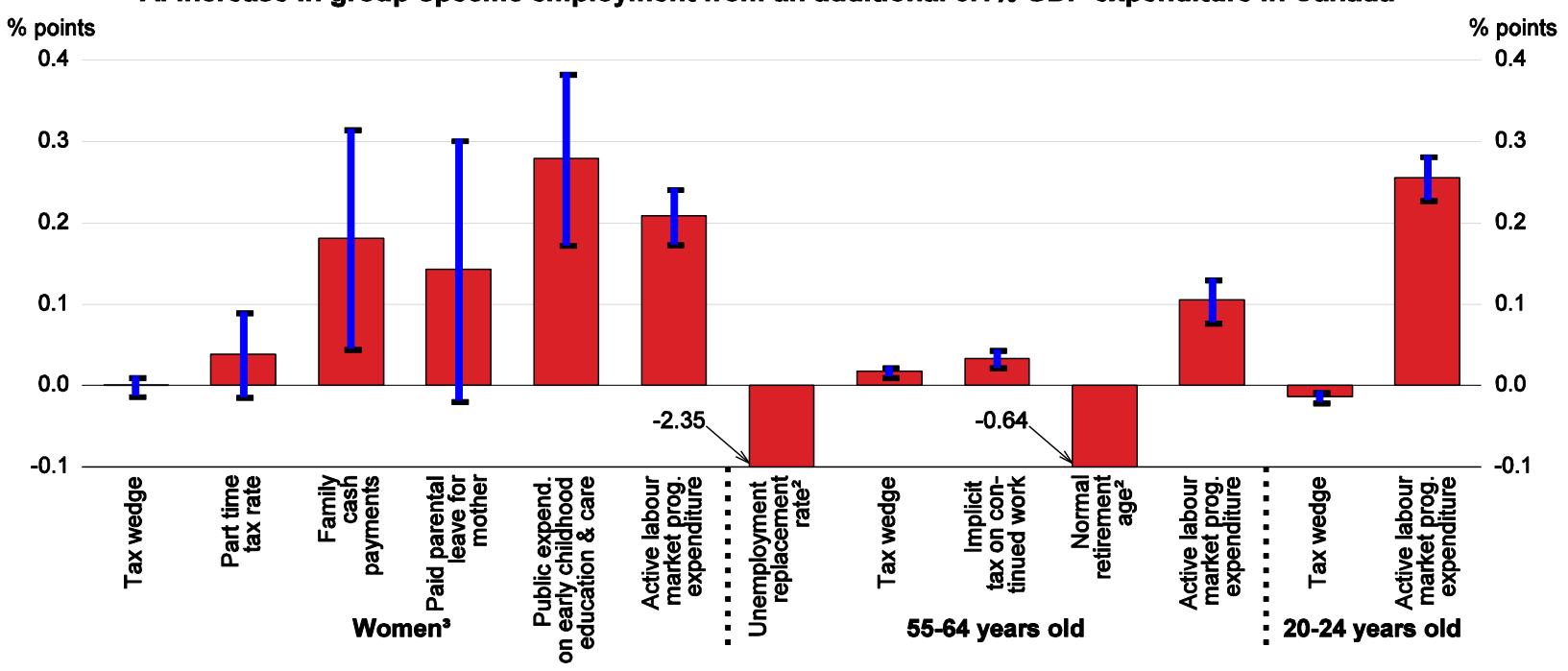

B. Increase in group-specific employment from moving Canada to the 80th percentile of 20 OECD countries included in the analysis sample 4

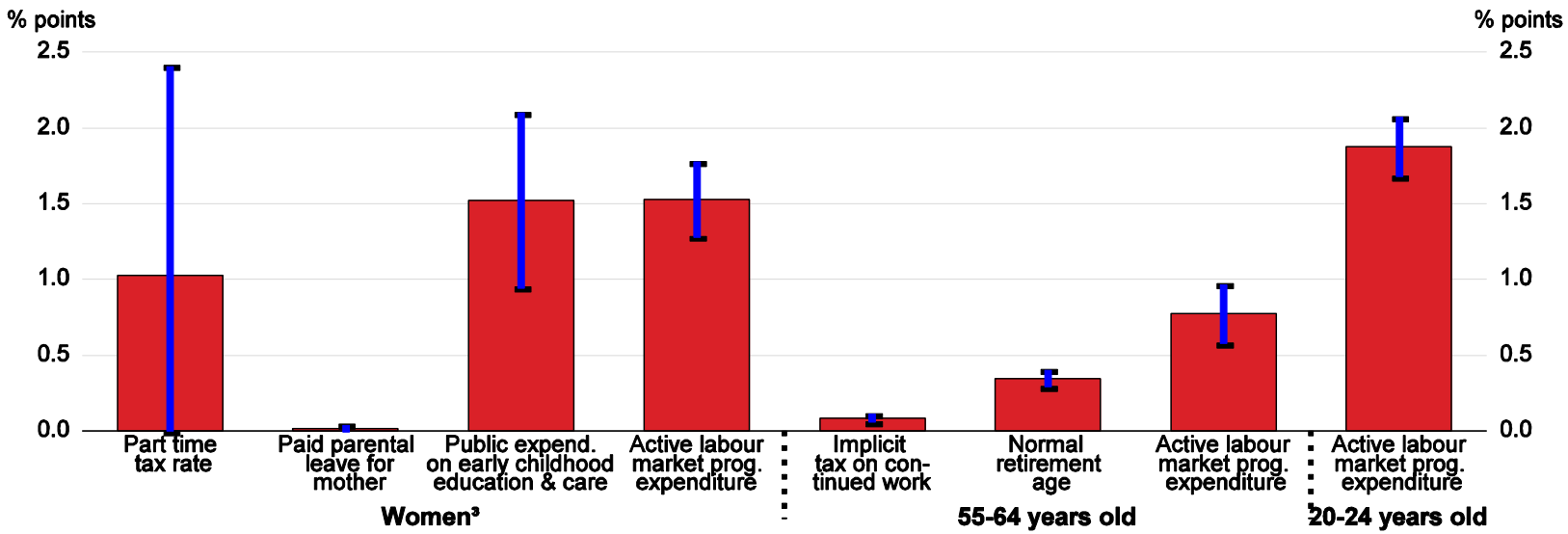

1. Columns show the estimated increase in group-specific employment rates, based on applying cross-country panel regression results to policy and budgetary data for Canada, using statistically significant parameter estimates only. Vertical blue lines represent confidence interval of \pm 1 standard errors around regression coefficients. Other control variables include union density, employment protection legislation, product market regulation, education for women and youth, number of children per woman, the estimated output gap, and country and year dummy variables. The analysis was undertaken separately for prime-aged women (aged 25 to 54), older workers and youth, with each estimated jointly with a prime-aged male employment equation using seemingly unrelated regression estimation applied to data for 1982 to 2014.

2. Reducing expenditure via reducing unemployment benefit replacement rates or increasing the normal retirement age is estimated to increase employment for those aged 55-64.

3. Estimates for women are a combination of estimated effects on full-time employment and on part-time employment, with the latter given a relative weighting of 0.75 . Parameter estimates that are significant for one or both full- and part-time are included.

4. Canada is already at or above the 80th percentile for family cash payments, the (small) size of the tax wedge, and the (low) unemployment replacement rate.

Source: OECD estimates using data from 1982-2014, based on the approach in Bassanini and Duval (2006) and estimating budgetary costs in Canada using Statistics Canada (2017), SPSD/M database and model. For analysis using SPSD/M, the assumptions and calculations underlying the simulation results were prepared by OECD staff and the responsibility for the use and interpretation of these data is entirely that of the authors. 
paper rely on a broader range of evidence than just cross-country panel analysis, as this can be sensitive to sample variation, heterogeneity in the effects of policies across countries and endogeneity between policy reforms and outcomes (Bassanini and Duval, 2006 $6_{[7]}$ ).

Indigenous Canadians trail the rest of the population in terms of participation and employment, which is an inclusiveness challenge but also an opportunity. The employment rate for the Indigenous population lagged that of the rest of the population by around 5 percentage points in 2016, similar to New Zealand Maori but only around one quarter of the gap between Indigenous and non-Indigenous Australians (Statistics Canada, 2017 ${ }_{[8]}$; Australian Government, 2017 ${ }_{[9]}$; MBIE, 2017 $\left.{ }_{[10]}\right)$. The Indigenous share of the working-age population is projected to increase from $3.5 \%$ in 2011 to $4.4 \%$ in 2036 . One-fifth of labour force growth in the next 20 years would be Indigenous if the labour force participation gap with other Canadians were to close (Drummond et al., $2017_{[11]}$ ). Lower educational attainment is one reason for poorer employment outcomes among Indigenous Canadians. Providing high-quality, culturally responsive ECEC to Indigenous children has been found to be the single most effective lever to improve education outcomes amongst Indigenous children (OECD, 2017 $\left.{ }_{[12]}\right)$. The federal government has committed CAD 360 million over three years to engage with Indigenous Peoples to develop an Indigenous Early Learning and Child Care Framework.

\section{Population health}

Canada has strong health outcomes in aggregate, reflected, for example, by high life expectancy at birth and at age 65 (Figure 9). The gap in life expectancy between those with high and low levels of education is among the smallest in the OECD (OECD, 2017[13]). Smoking and alcohol consumption are below the OECD average, but obesity rates are high. Indicators for access to and quality of health care are generally good, achieved under a system featuring universal coverage with a level of health spending not much higher than the OECD average (OECD, 2017[13]). However, a rapidly ageing population and the diffusion of new medical technologies will place a bigger burden on the health-care system over the coming decades. This includes increasing demand for long-term care, discussed further below with regard to inclusiveness for seniors.

As for incomes and employment, the Indigenous population is disadvantaged in terms of health outcomes. Indigenous people are less likely to report very good or excellent health, have higher rates of smoking and heavy drinking, and are more likely to report difficulty accessing first-contact health-care services (Statistics Canada, 2017 [14]; Clarke, 2016 ${ }_{[15]}$ ). Indigenous people trail non-Indigenous people in life expectancy, with the gap ranging from around five years (First Nations and Métis) to more than 10 years (Inuit) (Chief Public Health Officer, 2016 $\left.{ }_{[16]}\right)$. Appropriately, the federal government has made improving health outcomes for Indigenous Canadians a priority and allocated additional funding of CAD 1.5 billion over five years in the 2018 budget. 
Figure 9. Life expectancy

\section{A. LIfe expectancy at birth, 2016 or latest year avallable}

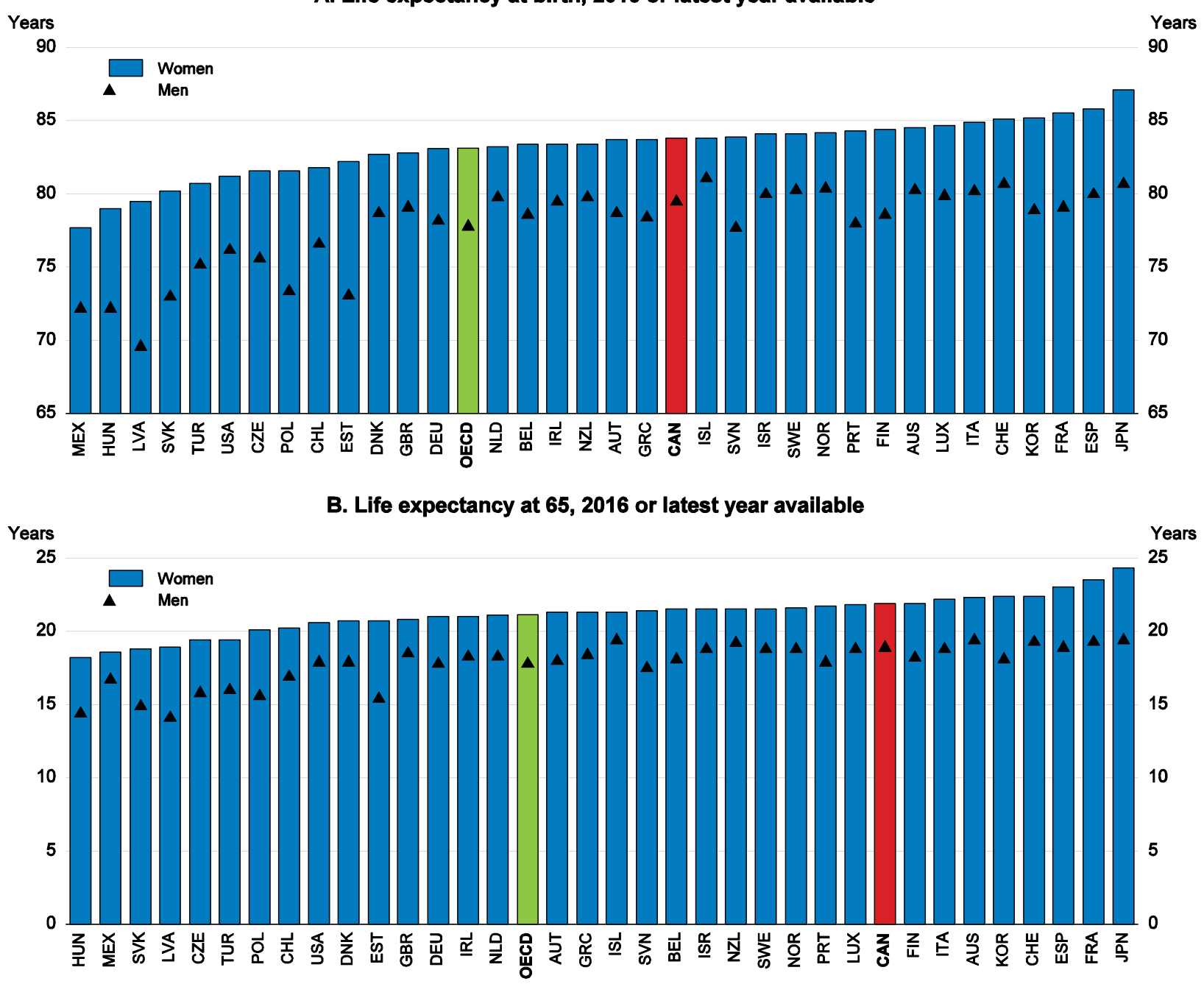

Source: OECD, Health database.

\section{Labour market policy issues relevant for women, youth and seniors}

\section{In-work benefits}

In-work benefits are employment-conditional cash transfers (including via the tax system) to individuals or families facing particular labour market challenges. They are an attractive policy option due to their capacity to reduce inequality at the same time as increasing employment (Immervoll and Pearson, 2009 $9_{[17]}$ ). While certain economic or institutional traits can limit the pay-off from in-work benefits or make them more costly, such as a narrow earnings distribution or high tax rates and benefits, these conditions are not present in Canada to the same extent as in some European countries. Where the wages of potential recipients of in-work benefits are low, these transfers can make a big difference to incomes and work incentives. In-work benefits have important interactions with other labour market policies, notably minimum wages (discussed below), which can prevent employers from "pocketing" the value of in-work tax benefits by reducing wages. 
In Canada, the Working Income Tax Benefit (WITB), introduced in 2005, is a refundable tax credit intended to provide tax relief for eligible low-income individuals and families who are already in the workforce and to encourage others to enter it. Each province/territory is permitted to tailor settings to their needs; this option has been taken up by Québec, British Columbia, Alberta and Nunavut. Single mothers and people under 30 are more likely than other Canadians to claim WITB credits (Department of Finance Canada, 2016 ${ }_{[18]}$ ). In 2017, the federal government spent $0.05 \%$ of GDP on the WITB (CAD 1.2 billion) compared with around $0.4 \%$ of GDP on similar tax credits in the United Kingdom and the United States. From 2019, the WITB will be renamed the Canada Workers Benefit, with access made automatic to those eligible and spending increased to around $0.09 \%$ of GDP in 2019 .

In-work benefits are most effective when customised to the distribution of working hours and earnings in the population, which for Canada means that there are likely to be benefits from provinces tailoring the implementation of the Canada Workers Benefit to the specific context of their populations and tax schedules. Recommendations regarding potential benefits from expanding in-work benefits to specific groups are picked up where relevant in the rest of the paper.

\section{Active labour market policies (ALMPs)}

ALMPs seek to get more people into jobs or improve the match between workers and vacancies, through support for those looking for work, such as job-search assistance and training. In Canada ALMPs are predominantly funded by the federal government and delivered by the provinces through Labour Market Transfer Agreements. Federal spending on ALMPs in 2015 was low in Canada compared with other OECD countries (Figure 10). In 2017 the federal government increased funding for Labour Market Transfer Agreements by around $15 \%$, broadened program eligibility and gave greater flexibility to the provinces in how they meet the needs of their local labour markets. While it is too early to assess the precise impacts, these changes should help to reverse substantial reductions in funding available to disadvantaged jobseekers from 2014, such as those ineligible for Employment Insurance support and people with low education or skills (Caledon Institute, 2014 ${ }_{[19]}$ ). ALMP spending in Canada is concentrated on training, which can have long-term positive impacts on participation, employment and earnings, but can also reduce short-term employment as participants have less time for job search.

Re-employment rates for displaced workers are lower in Canada than in Australia, New Zealand and the United States, but higher than in France (OECD, 2015 $5_{[20]}$ ). Prior to recent Labour Market Transfer Agreement changes, many displaced workers - especially those involved in small-scale or individual layoffs - have had access only to basic jobsearch assistance. Federal responsibility for Employment Insurance payments and provincial delivery of re-employment support can make the system difficult to navigate and weaken the clarity of mutual obligations for benefit recipients (OECD, 2015 [20]). Older displaced workers face the poorest re-employment prospects, while unemployment among youth has the potential to lead to long-term fiscal and welfare costs associated with scarring effects, particularly among disadvantaged youth (OECD, 2014 $\left.{ }_{[21]}\right)$. 
Figure 10. Spending on active labour market programmes per unemployed person is low ${ }^{1}$ In thousand USD PPPs, 2015 or latest available year

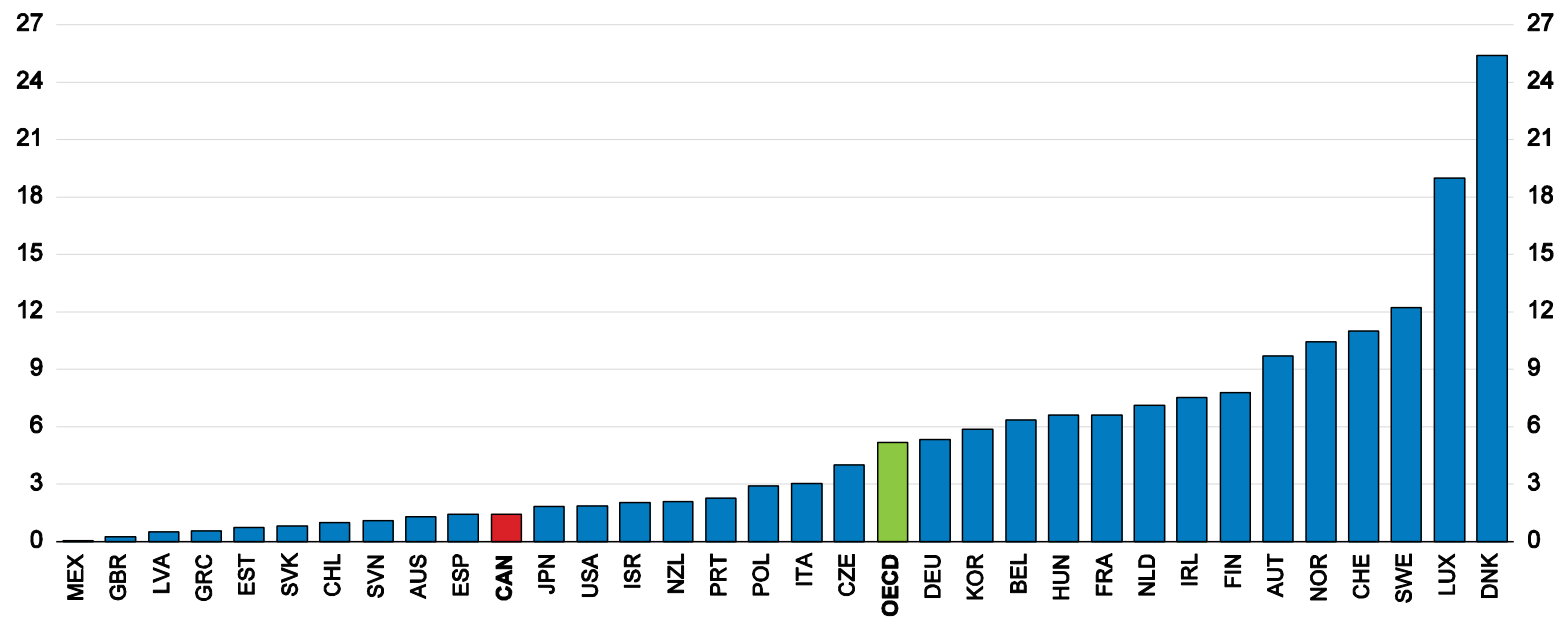

1. Data include federal expenditures on programmes implemented by the provinces and territories, but do not generally include the provinces' additional or complementary funding of these programmes.

Source: OECD, Labour Market Programmes/National Accounts/Annual Labour Force Statistics databases.

Further increasing funding for well-designed ALMPs has the potential to boost the employment of women, youth and older workers (Figure 8 above). Careful evaluations of ALMPs internationally reveal a mixed record but also show that well designed and targeted measures can increase the employability of jobseekers and their employment opportunities in a cost-effective manner (OECD, 2015 $5_{[22]}$ ). Higher ALMP spending is associated with higher GDP growth as well as greater resilience in terms of a lower likelihood of extreme negative growth events (Caldera-Sanchez et al., 2016 ${ }_{[23]}$ ). The effectiveness of in-work tax benefits is likely to be strengthened when they are combined with well-designed ALMPs, as demonstrated by the results of Canada's Self-Sufficiency Project (OECD, 2005 [24]; Immervoll and Pearson, 2009 ${ }_{[17]}$ ). Adverse employment effects of generous unemployment benefits have also been found to be less common in countries that spend more on ALMPs (OECD, 2006 $6_{[25]}$ ).

A systematic review of the effectiveness of existing ALMPs and their congruence with the employment barriers faced by youth, women and older workers would provide a sound basis for identifying gaps in currently available employment-support programmes. Such a review could draw on new data from the shared performance measurement strategy included in the new Labour Market Transfer Agreements. There is scope to expand funding in a number of ways, including by reinstating more assistance for disadvantaged jobseekers, relaxing eligibility conditions for successful programmes such as Ontario's Second Career Program (Malatest, 2016[26]), or providing more immediate and better-tailored assistance through systematic early needs assessment.

\section{Minimum wages}

Recent and prospective minimum wage increases (Table 1) will increase wages for employees at the bottom of the distribution, benefitting a relatively larger share of youth and women. In 2016 minimum wages in Canada averaged $46 \%$ of the median wage, just below the $50 \%$ average across 27 OECD countries for which data are available (OECD, $\left.2017_{[27]}\right)$. 
Table 1. Scheduled minimum wage increases vary considerably across provinces

\begin{tabular}{lccc}
\hline & \multicolumn{2}{c}{ Minimum wage as of: } & Percentage increase \\
\cline { 2 - 3 } & 1 January 2017 & 1 January 2019 & \\
\hline Newfoundland and Labrador & 10.50 & 11.22 & 6.9 \\
Prince Edward Island & 11.00 & 11.55 & 5.0 \\
New Brunswick & 10.65 & 11.22 & 5.4 \\
Nova Scotia & 10.70 & 11.07 & 3.4 \\
Québec & 10.75 & 12.00 & 11.6 \\
Ontario & 11.40 & 15.00 & 31.6 \\
Manitoba & 11.00 & 11.35 & 3.2 \\
Saskatchewan & 10.72 & 11.18 & 4.3 \\
Alberta & 12.20 & 15.00 & 23.0 \\
British Columbia & 10.85 & 12.65 & 16.6 \\
\hline
\end{tabular}

Note: In provinces where minimum wages as of 1 January 2019 are yet to be announced, these were calculated based on minimum wages as of 1 January 2018, incorporating 2\% CPI growth where minimum wages are indexed to the CPI.

Source: (Brouillette et al., 2017[28]); (Province of British Columbia, 2018[29]).

There is a risk of reducing employment if minimum wage increases are not properly differentiated (for example, across age groups or regions) and kept in line with the productivity of low-skilled workers. A statutory minimum wage is likely to reduce employment if set above a particular (albeit uncertain) level relative to the median. Young workers are most likely to be vulnerable to job losses resulting from a high level of the minimum wage, particularly as some provincial legislation stipulates lower minimum wages only for a small share of youth, such as students under 18. Nor do minimum wages differentiate for the higher cost of living (and average wages) in major cities such as Toronto and Vancouver. Most studies for Canada find that minimum wage increases have a statistically significant negative effect on employment, especially for younger workers, and researchers at the Bank of Canada have estimated that minimum wage increases during 2018 will lead to a $0.3 \%$ decline in employment (Brouillette et al., 2017 ${ }_{[28]}$ ).

Independent expert commissions, as used to determine wage increases in several OECD countries and the province of British Columbia, are well placed to consider a wide range of economic and social factors and make the necessary links between minimum wages and related policy areas. In general minimum wages are not well targeted toward poverty reduction, as in many cases they benefit individuals in non-poor households where other family members earn higher wages. Canadian studies have found that minimum wage increases have not reduced poverty rates, but have been successful in reducing inequality among wage earners (Green, 2015 $[30])$.

\section{Universal basic income}

One approach to sharing the benefits of growth is a universal basic income paid to all citizens. This concept has garnered increasing interest with the advent of widespread automation and the threat of labour market disruption from technological change. In Canada the Ontario government in 2017 put in place a pilot project in three communities to study the idea of a basic income (albeit with a design that is very different to a truly "universal" payment as eligibility is limited to those on low incomes at the commencement of the trial and does not replace existing benefits). In December 2017, the Government of Québec released its new Action Plan to Foster Economic Inclusion and Social Participation, 
which announced the progressive implementation of a basic income for social assistance recipients with a severely limited capacity for employment.

A universal "no questions asked" public transfer would be administratively simple, leave no-one without support and would not reduce work incentives for low-income earners in the same way as conditional or means-tested transfer payments (such as unemployment benefits) can do. However, the lack of targeting would mean either unrealistically low payments - replacing all non-elderly cash benefit spending would provide only enough funding for a universal payment of some $15 \%$ of the relative poverty line - or high fiscal costs, which if financed through increased income tax would reduce work incentives for households that already have significant earned income (OECD, 2017 [31]). An entirely unconditional basic income would also sever links between the rights and responsibilities of jobseekers. In countries where transfer systems perform well replacing existing systems with a universal basic income would result in a very large reduction in progressivity and losses in benefits for many poor households (IMF, 2017 [32]). To date, no country has put a basic income in place as a principal pillar of support for the working-age population.

\section{Inclusiveness for women}

Gender equality is a key focus of the current federal government, with all policy changes to be subjected to a new "gender results framework" and gender-based analysis of future budgets to be required by law $\left(\mathrm{OECD}, 2018_{[33]}\right)$. A number of measures were taken in the 2018 federal budget to advance gender equality, including combatting gender-based violence and harassment. Considerable progress is still needed for Canada to meet the Sustainable Development Goals on gender equality, notably in relation to the gender wage gap, disparities in unpaid work, violence against women and representation in parliament (McArthur and Rasmussen, 2017 ${ }_{[34]}$; OECD, 2017 $\left.{ }_{[35]}\right)$. Problems in most of these dimensions are especially severe when it comes to Indigenous women.

\section{Gender gaps in wages and employment reduce female incomes}

Employment rates for Canadian women continue to lag those of men, with no progress in shrinking the gap since 2009 (Figure 11, Panel A). In part the lack of any recent progress reflects the recovery from a male unemployment spike during the downturn, which hit hardest in male-dominated sectors (Moyser, 2017[36]). However, progress in closing the gender participation gap has also slowed over the past decade (Panel B).

As elsewhere, low employment rates are concentrated among women with young children and single mothers. Women with a child aged under six have an employment rate around 10 percentage points lower than those with older children or no children, whereas men with children are more likely to work than those without, and the age of their youngest child has little effect. Single mothers of children up to the age of 18 have a similar employment rate to women with a child aged under six (Moyser, 2017[36]).

Geographic patterns in employment suggest that mothers of young children would like to work more if they had access to affordable childcare and other family-friendly measures (see below). The gender employment gap is greater in localities with high childcare fees, notably in Toronto and Vancouver, than in those with lower childcare costs, notably in the province of Québec, which introduced low-fee childcare in 1997. Comparison within a single urban area (Ottawa-Gatineau) illustrates the desire of women for greater employment where low-fee childcare (as well as other family-friendly measures) is available: the gender employment gap on the Québec side is only 2.6 percentage points, 
compared with 7.3 points on the Ontario side (Moyser, 2017 $[36]$ ). The desire for women to work more is consistent with survey evidence from Europe, where a substantial share of couples would prefer to have two earners than a single breadwinner (Steiber and Haas, $\left.2015_{[37]}\right)$.

Figure 11. Labour market gender gaps are relatively small but no longer shrinking

Difference between male and female rates, population aged 15-64 years old

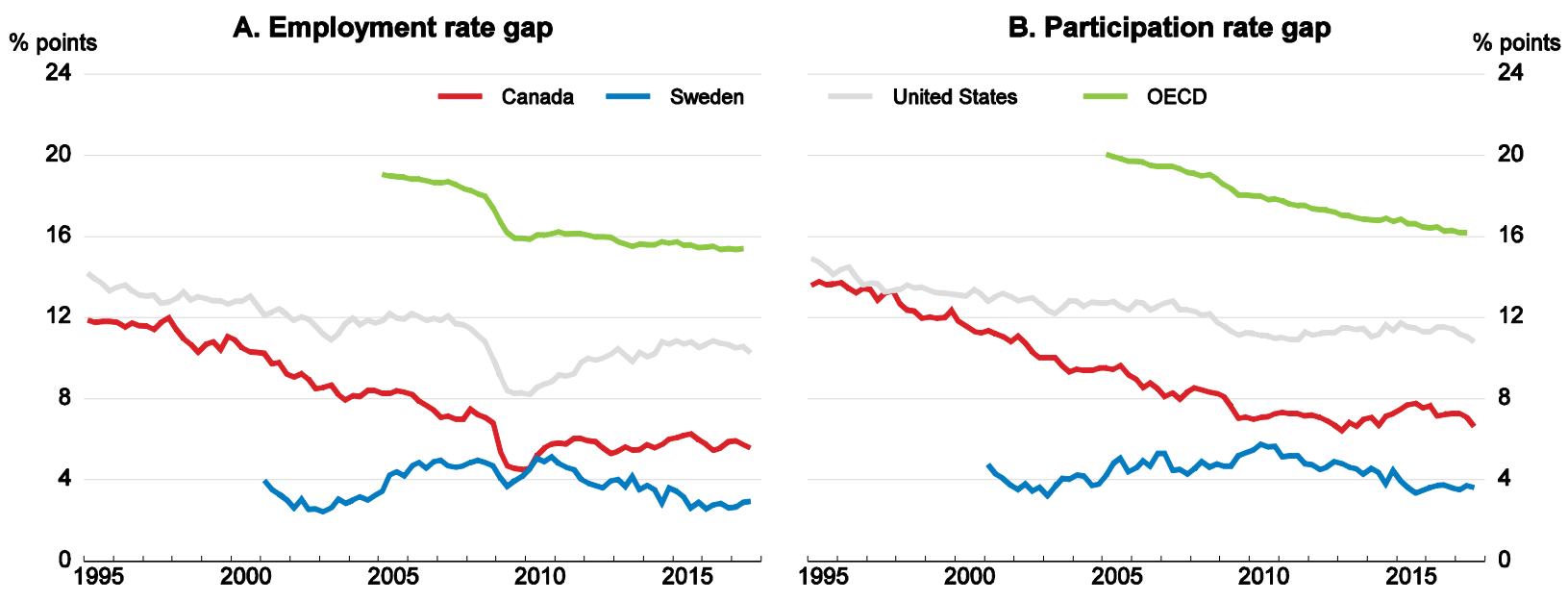

Source: OECD, Short-Term Labour Market Statistics database.

Women earn significantly less than men, particularly mothers. On an hourly basis, women who worked full-time in 2017 earned 88 cents on average for each dollar earned by men. Women also work less hours on average, so the gap in total earnings is larger again at $18 \%$, considerably higher than the OECD average of $14 \%$ (OECD, 2018 $\left.8_{[38]}\right)$. The hourly wage gap has been roughly stable since 2010 after increasing from 75 cents in the mid-1980s (Moyser, 2017 [36]). Depending on the province or territory, around one-third to a half of the gender wage gap can be explained by differences in education, occupation and industry of work (Schirle, 2015 $5_{[39]}$ ). An important factor is women's under-representation in topearning management and leadership positions, in part due to challenges faced by mothers in reconciling work and childcare responsibilities in jobs at the top of the earnings distribution (Fortin, Bell and Böhm, 2017 $[40]$ ). Women in Canada hold a similar or larger share of senior positions than the OECD average, but their representation still lags their $47 \%$ share of the labour force and they have made less progress in recent years (Figure 12). Nine OECD countries that have introduced quotas have seen more immediate increases in the number of women on boards than those such as Canada that have relied on disclosure or targets (OECD, 2017 $[35])$. A higher share of women on boards is associated with better corporate performance in some cases (Post and Byron, 2015 ${ }_{[41]}$ ) and with stronger corporate social responsibilities (Bear, Rahman and Post, 2010 ${ }_{[42]}$ ). 
Figure 12. Women in management positions

Percentage share filled by women
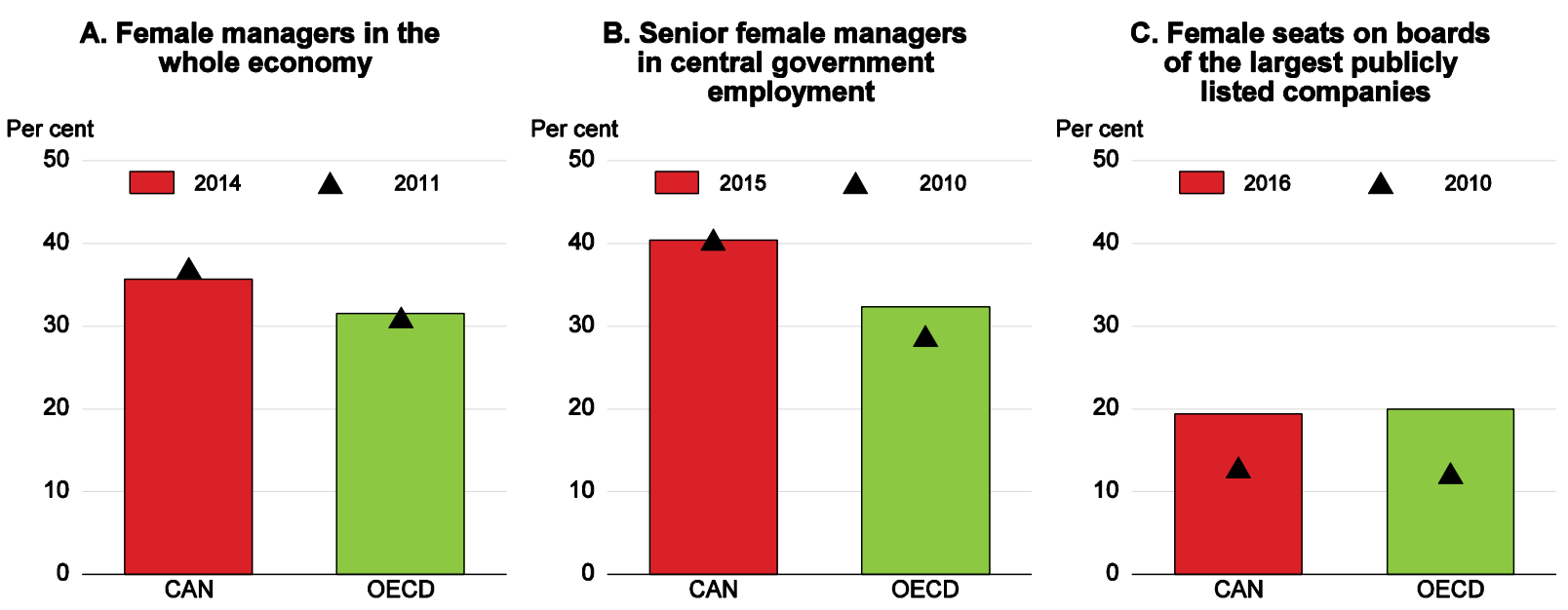

Source: OECD (2018), “Gender-Employment” in Social Protection and Well-being database; OECD (2017), Government at a Glance database.

In its 2018 Budget, the federal government committed to introducing new pay equity legislation to ensure that on average women and men in federally regulated public and private sectors receive the same pay for work of equal value. While this is a worthwhile aim and has symbolic value, in practice it is difficult to objectively evaluate the value of different types of work and similar provincial schemes have had mixed success. McDonald and Thornton $\left(2016_{[43]}\right)$ estimate that pay equity legislation in Quebec reduced the wage gap by $3.8 \%$ (at the cost of slightly lower employment for women), while pay equity had a negligible effect on the wage gap in Ontario. Baker and Fortin $\left(2004_{[44]}\right)$ also found that pay equity law in Ontario had no effect on the gender wage gap and argue that it is difficult to apply in decentralised labour markets.

The importance of differences in unpaid caring responsibilities in Canada is highlighted by the large gap between earnings of women with children and men or women without children (Figure 13). These total earnings gaps are partly explained by differences in hours of paid work, as women tend to spend more time on unpaid labour such as housework, childcare and eldercare. The gap in time spent on childcare activities between women and men in Canada is the highest among 10 OECD countries for school-aged children (Figure 14). Vincent $\left(2013_{[45]}\right)$ argues that just over half of the motherhood earnings penalty can be explained by fewer years of work experience and more hours devoted to unpaid work. 
Figure 13. The gender earnings gap is especially severe for working mothers ${ }^{1}$

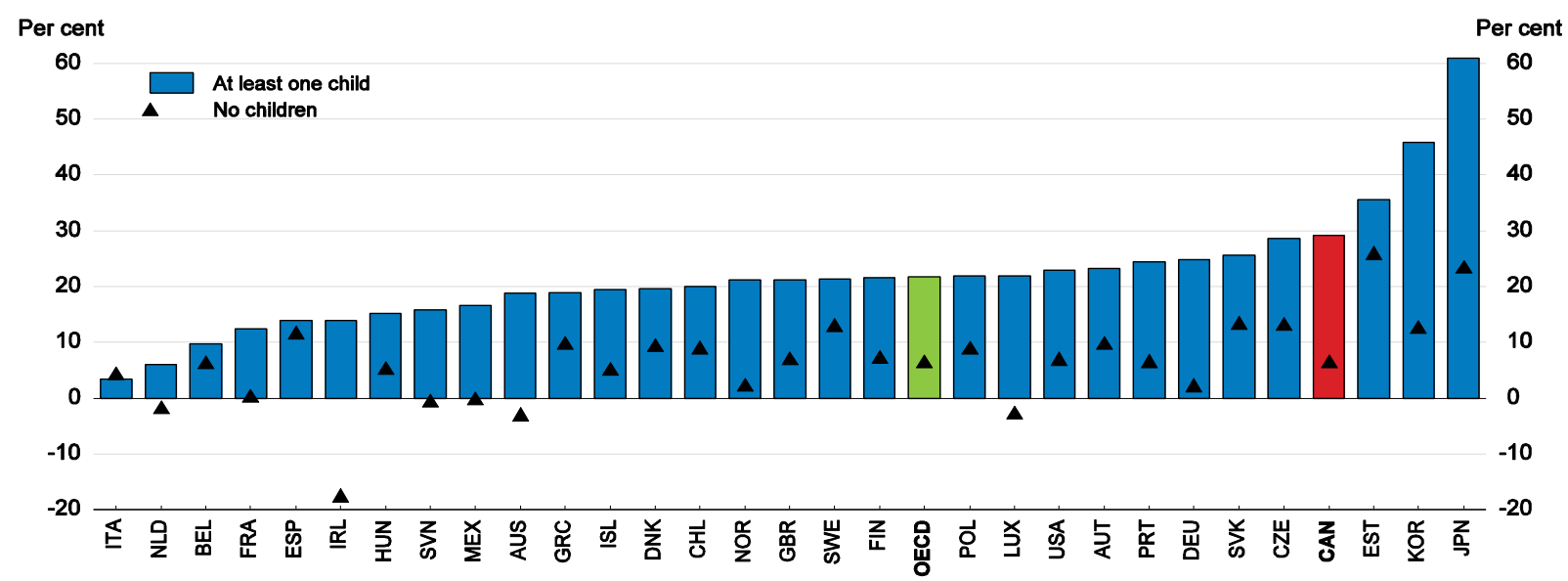

1. Earnings gap calculated for men and women aged 25-44 working full-time. Children defined as aged less than 16 years old.

Source: OECD (2012), Closing the Gender Gap: Act Now, Figure 13.3.

Figure 14. Canadian men spend less time on childcare activities than their female spouses ${ }^{1}$ Difference in time spent on childcare activities, by youngest child's age, in minutes per day

\section{A. Child(ren) below school age}

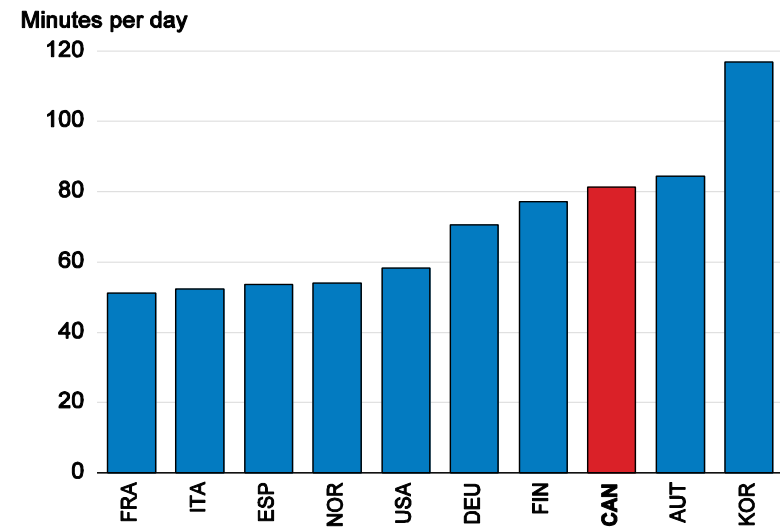

\section{B. School-aged children}

Minutes per day

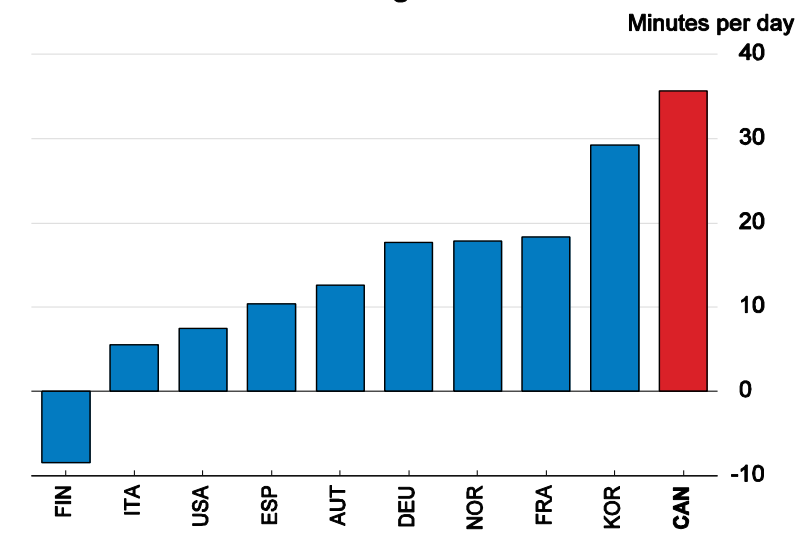

1. Data for partnered men and women (those who live in the same household as a spouse or cohabitating partner, married or not) in couples with a female partner aged 25-45, only. Pensioners and students excluded. Data restricted to "carers", i.e., mothers and fathers who are engaged in at least one childcare activity during a timeuse diary day.

Source: OECD (2017), The Pursuit of Gender Equality: An Uphill Battle, Figure 15.2.

\section{Increase fathers' use of parental leave}

Parental leave available for Canadian women is around the middle of OECD countries' programmes in terms of both the duration of paid leave and the generosity of payment rates (Figure 15). Under the Employment Insurance system, mothers are eligible for 15 weeks of maternity leave (after a one-week unpaid waiting period) followed by up to 35 weeks of parental leave. At the conclusion of leave, employers are generally required to allow the employee to return to the same job they had before the leave began, or a comparable job if the old job no longer exists. Parental leave is paid through the employment insurance system at $55 \%$ of mean insured earnings. Parental leave may be taken by either parent, but 
take-up is overwhelmingly by mothers: on average, $89 \%$ of eligible mothers received maternity or parental benefits, while just $13 \%$ of fathers claimed or intended to claim parental benefits in 2016 (Statistics Canada, 2017 ${ }_{[46]}$ ). To qualify for benefits, new parents must have accumulated at least 600 hours of insured earnings in the previous year.

Figure 15. Paid leave entitlements for mothers are near the OECD average

Paid maternity, parental and home care leave available to mothers, April $2016^{1}$

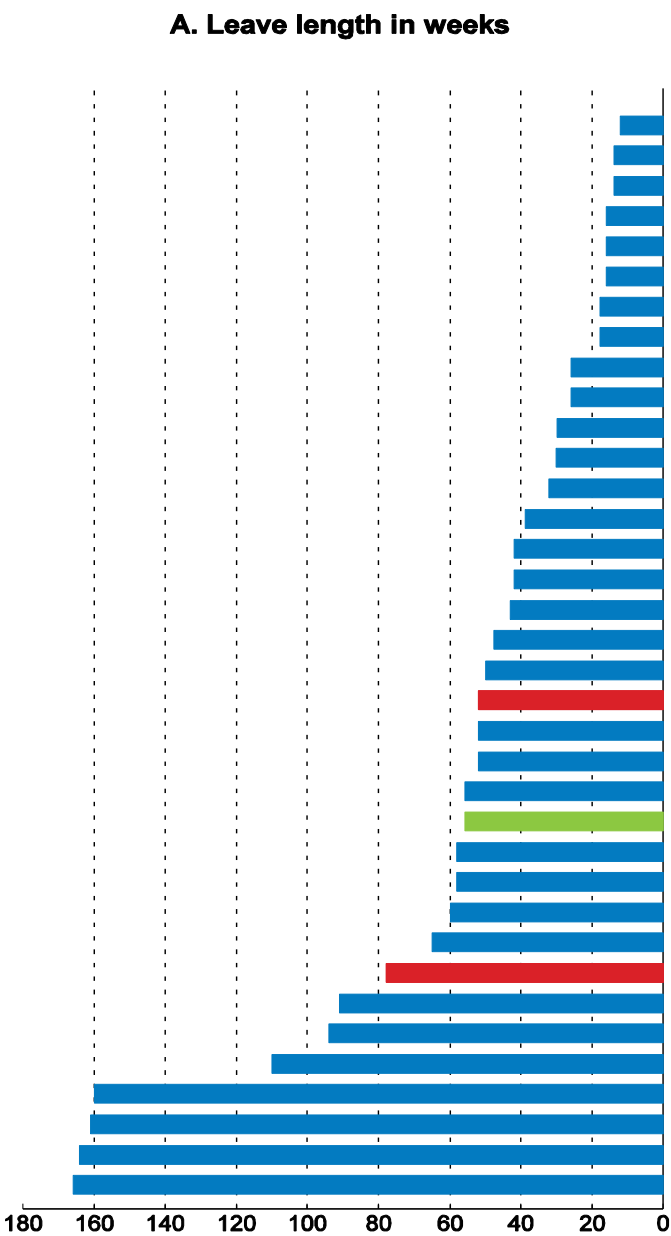

B. Average payment rate (\%)

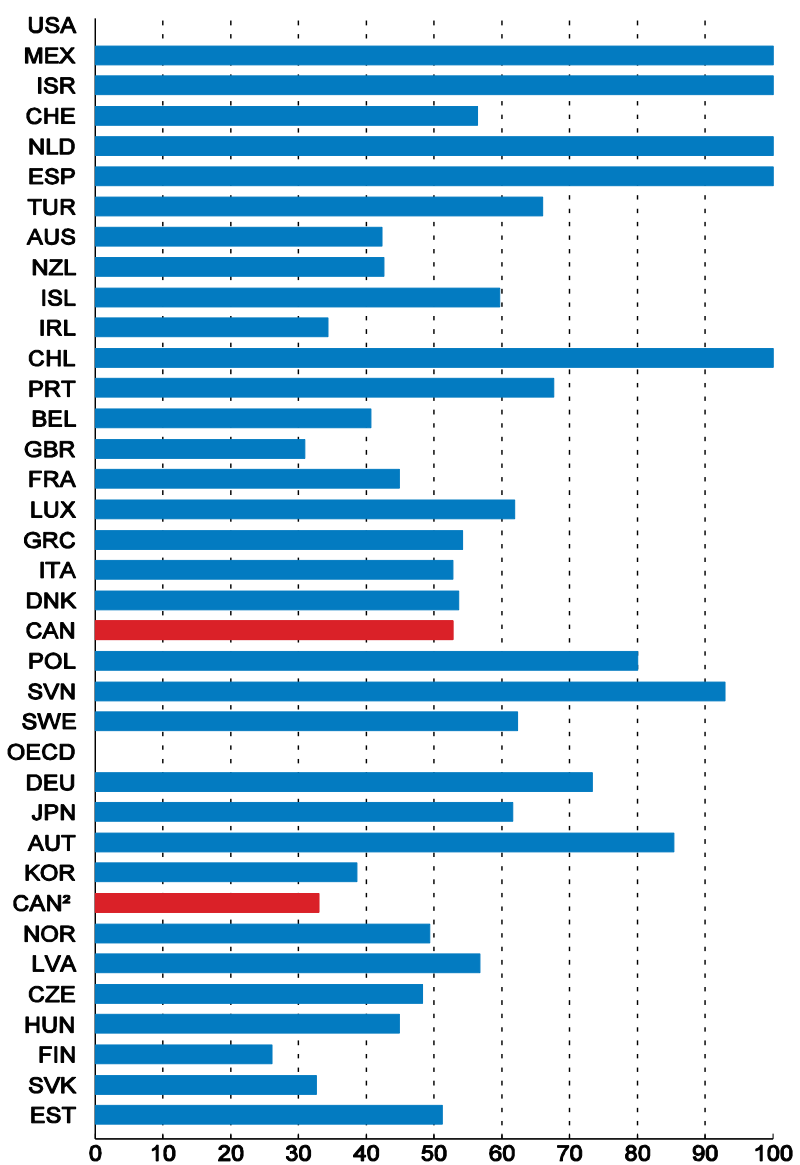

1. For more detail, see notes in Source. Data for Canada exclude Quebec.

2. New leave option introduced in the 2017 federal Budget.

Source: OECD (2017), Family database, Table PF2.1.A; Ministry of Finance (2017), "Building a Strong Middle Class - Budget 2017”, presented to the House of Commons, 22 March.

Changes announced in the 2017 Budget allow new parents to choose between standard parental benefits, or taking a longer leave period of 18 months, paid at a lower replacement rate of $33 \%$. Pressure on family budgets is likely to constrain take-up, but, for those who do opt for the longer leave period, the reduced level of income support and prolonged period out of work have the potential to weaken labour force attachment. Nor does this option support inclusiveness, as only those who are relatively well-off are likely to be able to afford the extended loss of income. While cross-country analysis indicates that extending parental leave available to mothers beyond one year is associated with greater work force participation among women (Thévenon and Solaz, 2013 [47]; Adema, Clarke and Frey, 
$2015_{[48]}$ ), there is also a risk of damaging women's human capital development, career progression and wages (Thévenon and Solaz, 2013 [47]; Cukrowska-Torzewska, 2016 ${ }_{[49]}$ ).

In the province of Québec, new parents are eligible for 43-55 weeks of maternity and parental benefits, paid at a rate of $55-75 \%$, depending on the plan chosen. Take-up by eligible mothers, at almost $97 \%$, is much higher than in the rest of the country. Part of paid parental leave (3-5 weeks) is reserved specifically for fathers, whose take-up rates are much higher than elsewhere: $80 \%$ of fathers claimed or intended to claim parental benefits in Québec in 2016, compared with 28\% in 2005 prior to the introduction of leave reserved for fathers (Statistics Canada, 2016 $[50]$ ). Québec's parental-leave programme has a lower threshold for eligibility of CAD 2000 in insured wages, or around one third as many hours as required in the rest of the country (at the minimum wage). While a wage-based threshold undermines targeting by making it easier for high-income earners to qualify, there may be value in revisiting whether the hours test in the rest of Canada is too strict (Robson, $\left.2017_{[51]}\right)$.

Increasing fathers' low take-up of parental leave in Canada (outside Québec) would offer inclusiveness benefits for women by increasing gender equality in unpaid childcare and wages. The bulk of international evidence indicates that fathers who take leave are more likely to take an active role in childcare both early on and after they return to work (see, for example, Almqvist and Duvander (2014 $\left.4_{[52]}\right)$; Boll, Leppin and Reich (2014 $\left.{ }_{[53]}\right)$; Nepomnyaschy and Waldfogel $\left(2007_{[54]}\right)$; and Sullivan et al. $\left.\left(2009_{[55]}\right)\right)$. Gender equality in couples' division of labour is especially likely when fathers take longer periods of leave (Huerta et al., 2013 ${ }_{[56]}$ ) or take leave while their partner is working (Bünning, 2015[57]). International studies seeking to identify causal effects of paternity leave by comparing specific behaviour of parents before and after changes in policy are inconsistent in their findings. Kotsadam and Finseraas $\left(2011_{[58]}\right)$ find that sharing of household labour became more equal in Norway after the introduction of a "Daddy quota", but Ekberg, Erikson and Friebel $\left(2013_{[59]}\right)$ find that sharing of leave for sick children in Sweden did not. However, a recent study found evidence that the introduction of leave for fathers in Québec had longrun positive effects on the distribution of childcare and domestic work responsibilities (Patnaik, 2018[60]).

Gender differences in time spent on paid work are smaller in countries where gender differences in unpaid work are smaller, while several studies find that within couples female labour supply is positively related to male household labour (Adema, Clarke and Frey, 2015 $[48]$ ). Parental leave by fathers can also serve to reduce gender wage gaps by increasing maternal earnings and/or decreasing paternal earnings (Johansson, 2010 [61]; Albrecht, Thoursie and Vroman, 2015 [62] $)$ and may help reduce gender discrimination in the workplace and the risk that women are the only ones taking care-related leave (Rønsen and Kitterød, 2015 [63]).

The federal government's announcement of an additional five weeks (or eight weeks at a lower pay rate) of non-transferable leave for second parents (usually fathers, but also available to adoptive and same-sex couples) in its 2018 budget is welcome and brings Canada into line with many other OECD countries. It is important to ensure fathers take their leave entitlement: strong causal take-up effects of the introduction of father-specific leave have been documented in Norway (Dahl, Løken and Mogstad, 2014 ${ }_{[64]}$ ), the province of Québec (Patnaik, 2018[60]) and Sweden (Ekberg, Eriksson and Friebel, 2013 [59]), but take-up is low in some other OECD countries, such as France, Japan and Korea (OECD, $\left.2016_{[65]}\right)$. Critical here is ensuring that leave reserved for fathers (who are typically older and earn more than mothers) is generous enough to avoid prohibitive pressure on household 
budgets - payment rates for paternity leave in France (31\%), Japan (58\%) and Korea (30\%) are all below the OECD average of $69 \%$ of median wages (OECD, 2017 [66] $)$. In this respect Québec differs from the rest of Canada not only in having parental leave reserved specifically for fathers, but also in terms of the higher rate of pay available for both mothers and fathers: a maximum replacement rate of $75 \%$ and a higher ceiling on insured income of CAD 74 000, compared with 55\% and CAD 51700 in the rest of Canada. Take-up of new parental leave should be monitored and increased payment rates for parental leave considered if take-up is weak. This is an area that would benefit from gender-based analysis of the consequences of different payment rates, applying the framework set out in OECD (2018[33]).

Workplace culture is also important, with organisational support critical for parental-leave policies to have their intended effect (Tremblay and Genin, 2010 $[67]$ ). While nontransferable parental leave for the second parent could conceivably shift societal norms about parenthood and sharing of paid and unpaid work (Rønsen and Kitterød, 2015 [63]), governments at all levels should further ensure take-up by fathers through information provision and leading by example in the public service. Governments can assist women in employment through promoting workplace flexibility by granting all employees a right to request flexible working arrangements (as enacted for federally regulated employees in 2017), encouraging social partners to cover workplace flexibility in collective bargaining, and helping companies change work organisation through the exchange of best practice and information campaigns (OECD, 2017 $\left.{ }_{[35]}\right)$.

\section{Increase the availability and affordability of high-quality early childhood education and care (ECEC)}

While there is a lack of nationally consistent data, researchers have collated federal and provincial estimates that indicate Canadian governments spend around $0.6 \%$ of GDP on ECEC (Akbari and McCuaig, 2018[68] $)$, boosted by high spending on kindergarten but still just below the OECD-wide average of $0.7 \%$ (OECD, 2017 $[66]$ ). Net (after-tax) childcare costs for families with young children vary across Canada. In Ontario, these costs are high (Figure 16). As a result, the proportion of gross earnings absorbed by tax, childcare payments or reduced social benefits (participation tax rates) is well above the OECD average and exceeds $100 \%$ for low earners (OECD, 2017 $[69])$.

By international comparison, Canada provides relatively generous family cash benefits through the Canada Child Benefit. These benefits provide one source of funds for families to pay for childcare. However, they do not reduce the marginal cost of childcare (and associated participation tax rates), and thus, while family cash benefits can have benefits from reducing poverty among families, they are less desirable than childcare subsidies for raising female employment (Schirle, 2015 [70]; Jaumotte, 2004 $\left.{ }_{[71]}\right)$. 
Figure 16. The net cost of childcare ${ }^{1}$ for a couple family in 2015 was relatively high

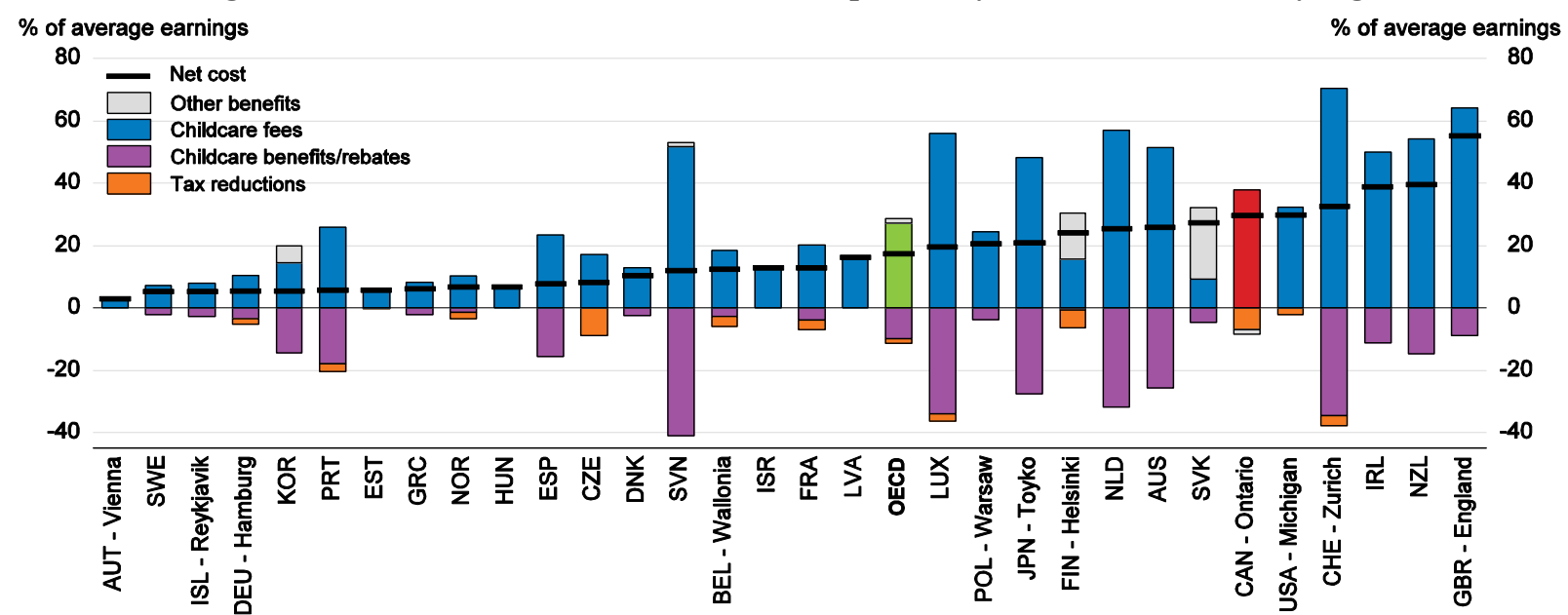

1. Effect of childcare costs for a couple family with two children, aged two and three, with both parents working full time and earning $100 \%$ and $67 \%$ of average earnings.

Source: OECD, Tax-Benefit Model and Policy database, http://www.oecd.org/els/benefits-and-wagesstatistics.htm.

Even where parents are willing and able to pay for childcare, there is a lack of high-quality spaces in many parts of Canada. There are spaces to cover less than $25 \%$ of Canadian 0 5 year olds (Anderson, Ballantyne and Friendly, 2016 $6_{[72]}$ ). Shortages are concentrated among young children: enrolment rates for children aged 0 to 4 are around 10 percentage points below the OECD average (Alexander et al., 2017 [73]). As kindergarten is offered for five year-olds in all provinces and territories, enrolment rates for children aged 5 are roughly in line with the OECD average.

There are a number of initiatives underway at the federal and provincial levels to improve childcare provision (Table 2). The federal government allocated an additional CAD 7.5 billion over 11 years in its 2016 and 2017 budgets to support and create more high-quality, affordable childcare spaces and to implement the Multilateral Early Learning and Child Care Framework. Canadian governments have committed to increase quality, accessibility, affordability, flexibility, and inclusivity in early learning and child care, with consideration of families that need child care the most.

While federal and provincial initiatives are promising, Canadian governments need to do more to support childcare. Affordable and high-quality ECEC can increase labour force participation of women (OECD, 2017 $[74]$ ), increase mothers' wages and reduce the motherhood wage penalty (Misra, Budig and Boeckmann, 2011 ${ }_{[75]}$ ). In Québec, the introduction of low-fee childcare is estimated to have delivered net fiscal benefits over the long-term (Box 1). Increasing public expenditure on childcare in Canada to match the 80th percentile of OECD countries is estimated to boost female employment by 1.5 percentage points (Figure 8 above). ECEC is also important for child development, particularly for disadvantaged children: international studies, programme evaluations and quality measurements have repeatedly shown that access to ECEC programmes has positive effects on children's well-being, learning and development. Two years of pre-primary education has been found to be the minimum needed to have a good chance of reaching a good level of performance at age 15, at which age standardised testing is 
Table 2. Recent provincial initiatives to improve early childhood education and care

\begin{tabular}{|c|c|c|c|}
\hline & Programme & Funding & Key initiatives \\
\hline Alberta & $\begin{array}{l}\text { Early Learning and } \\
\text { Child Care Centres }\end{array}$ & CAD 10M & Pilot programme with fees capped at CAD 25 per day. \\
\hline \multirow[t]{2}{*}{$\begin{array}{l}\text { British } \\
\text { Columbia }\end{array}$} & $\begin{array}{l}\text { Universal childcare } \\
\text { plan }\end{array}$ & $\begin{array}{l}\text { CAD 1B over } \\
3 \text { years }\end{array}$ & $\begin{array}{l}\text { Affordable child care benefit providing up to } \\
\text { CAD } 1250 \text { per month in conjunction with a new child care } \\
\text { fee reduction programme. Creation of more than } 22000 \\
\text { new licensed child care spaces. }\end{array}$ \\
\hline & Bilateral agreement & $\begin{array}{l}\text { CAD 153M over } \\
3 \text { years }\end{array}$ & $\begin{array}{l}\text { Developing prototype centres to test the introduction of } \\
\text { universal child care; significantly reduced parent fees. }\end{array}$ \\
\hline Manitoba & $\begin{array}{l}\text { Bilateral agreement } \\
\text { with federal } \\
\text { government }\end{array}$ & $\begin{array}{l}\text { CAD 47M over } \\
3 \text { years }\end{array}$ & $\begin{array}{l}\text { Creation of } 1400 \text { more affordable child care spaces } \\
\text { targeted at lower-income, French-language and newcomer } \\
\text { families, as well as underserved communities. } \\
\text { Core professional development training for up to } \\
100 \text { facilitators, providers and facilities. }\end{array}$ \\
\hline $\begin{array}{l}\text { New } \\
\text { Brunswick }\end{array}$ & $\begin{array}{l}\text { Bilateral agreement } \\
\text { with federal } \\
\text { government }\end{array}$ & $\begin{array}{l}\text { CAD } 30 \mathrm{M} \text { (federal) } \\
+41 \mathrm{M} \text { (provincial) } \\
\text { over } 3 \text { years }\end{array}$ & $\begin{array}{l}\text { More affordable, inclusive and high-quality early learning } \\
\text { and childcare services. } \\
\text { More spaces for infants and toddlers to address gaps. } \\
\text { Increase professional learning opportunities for educators. }\end{array}$ \\
\hline $\begin{array}{l}\text { Newfoundland } \\
\text { and Labrador }\end{array}$ & $\begin{array}{l}\text { Bilateral agreement } \\
\text { with federal } \\
\text { government }\end{array}$ & $\begin{array}{l}\text { CAD } 22.5 \mathrm{M} \text { over } \\
3 \text { years }\end{array}$ & $\begin{array}{l}\text { Up to } 540 \text { children to have access to free or low-cost child } \\
\text { care. Increase in quality and training for child care centres } \\
\text { serving up to } 1750 \text { children. }\end{array}$ \\
\hline Nova Scotia & $\begin{array}{l}\text { Bilateral agreement } \\
\text { with federal } \\
\text { government }\end{array}$ & $\begin{array}{l}\text { CAD } 35.5 \mathrm{M} \text { over } \\
3 \text { years }\end{array}$ & $\begin{array}{l}\text { Greater access to affordable childcare in remote areas } \\
\text { through creation of } 15 \text { new child care centres, } 500 \text { new child } \\
\text { care spaces, and } 90 \text { new family day care sites. }\end{array}$ \\
\hline Nunavut & $\begin{array}{l}\text { Bilateral agreement } \\
\text { with federal } \\
\text { government }\end{array}$ & $\begin{array}{l}\text { CAD } 7 \mathrm{M} \text { over } \\
3 \text { years }\end{array}$ & $\begin{array}{l}\text { All } 39 \text { centres will benefit from training and as many as } \\
838 \text { children will benefit from continued access to child care }\end{array}$ \\
\hline \multirow[t]{2}{*}{ Ontario } & $\begin{array}{l}\text { Renewed Early } \\
\text { Years and Child } \\
\text { Care Policy } \\
\text { Framework; Free } \\
\text { Preschool Care }\end{array}$ & $\begin{array}{l}\text { CAD 1.6B capital } \\
\text { expenditure over } \\
5 \text { years and a } \\
\text { further CAD } 2.2 \mathrm{~B} \\
\text { over } 3 \text { years }\end{array}$ & $\begin{array}{l}\text { Expectation to double the current capacity of licensed } \\
\text { childcare for children aged } 0 \text { to } 4 \text { in the province. } \\
\text { Free child care for children aged two and a half until they } \\
\text { are eligible for kindergarten, beginning September } 2020 \text {. }\end{array}$ \\
\hline & $\begin{array}{l}\text { Bilateral agreement } \\
\text { with federal } \\
\text { government }\end{array}$ & $\begin{array}{l}\text { CAD } 434.6 \mathrm{M} \text { over } \\
3 \text { years }\end{array}$ & $\begin{array}{l}\text { Up to } 100 \text { new Ontario Early Years Child and Family } \\
\text { Centres, supporting as many as } 100000 \text { more child and } \\
\text { family drop-in visits. Up to } 11200 \text { children supported via } \\
\text { additional fee subsidies or equivalent financial supports. }\end{array}$ \\
\hline $\begin{array}{l}\text { Prince } \\
\text { Edward Island }\end{array}$ & $\begin{array}{l}\text { Bilateral agreement } \\
\text { with federal } \\
\text { government }\end{array}$ & $\begin{array}{l}\text { CAD } 10.5 \mathrm{M} \text { over } \\
3 \text { years }\end{array}$ & $\begin{array}{l}\text { Up to } 100 \text { children whose parents work non-standard or } \\
\text { seasonal hours can receive specialised child care tailored to } \\
\text { their needs. Up to } 200 \text { infants and preschool children will be } \\
\text { able to access a regulated space. }\end{array}$ \\
\hline Yukon & $\begin{array}{l}\text { Bilateral agreement } \\
\text { with federal } \\
\text { government }\end{array}$ & $\begin{array}{l}\text { CAD 7M over } \\
3 \text { years }\end{array}$ & $\begin{array}{l}\text { Support } 90 \% \text { of child care centres in maintaining fees } \\
\text { without increasing costs to parents. }\end{array}$ \\
\hline
\end{tabular}

Source: Alberta Government (2016), Improving Access to Quality, Affordable Child Care, Announcement; BC NDP (2017), Working for You: Our Commitments to Build a Better BC, Election Platform; Government of Canada, Early Learning and Child Care Bilateral Agreements; Ontario Ministry of Education (2017), Ontario's Renewed Early Years and Child Care Policy Framework; Ontario Ministry of Education (2017), Ontario Making Child Care More Accessible and Affordable for Families, News Release; Ontario Government (2018), 2018 Ontario Budget: A Plan for Care and Opportunity.

undertaken as part of the Programme for International Student Assessment (OECD, $2017_{[74]}$ ). Historically, a small share of disadvantaged Canadian children has received two years of early childhood education (Figure 17). Using Québec as a benchmark for the upfront costs of universal ECEC indicates that long-term increases in federal government funding will be insufficient, even if provincial funding increases at the same rates. Projected funding of CAD 870 million in 2027-28 would be inadequate to achieve similar 
coverage to that in Québec, as preliminary research suggests this would cost around CAD 7.5 billion annually (Fortin, 2018[76]).

\section{Box 1. The introduction of low-fee childcare in Québec}

A low-fee universal childcare programme was initiated in the province of Québec with the Educational Childcare Act in 1997. The programme had two explicit objectives: to improve work/life balance and to enhance child development, with an eye on equality of opportunity. By 2014, the number of regulated childcare spaces had expanded to cover around $60 \%$ of children aged 0 to 4 , up from less than $20 \%$ in 1998 (Fortin, 2016 $[77]$ ).

Québec's childcare programme has succeeded in increasing female labour force participation. Participation for women with children under 6 increased by 16 percentage points between 1997 and 2016 in Québec, compared with a 7 percentage point increase in Canada as a whole (Statistics Canada, 2017 ${ }_{[8]}$ ). Female employment was boosted to such an extent that, based on comparison with the rest of Canada as a baseline, the introduction of low-cost childcare has been estimated in one study to have improved the combined federal-Québec governments' fiscal positions (Fortin, Godbout and St-Cerny, $2013_{[78]}$ ). This result has been achieved despite annual funding costs of CAD 3.3 billion ( $0.8 \%$ of GDP) incurred by the provincial government (Akbari and McCuaig, 2018 ${ }_{[68]}$ ).

Outcomes for child development have been more mixed. In aggregate, the introduction of universal childcare in Québec has been estimated to have had no significant effect on cognitive development, but a negative effect on development of non-cognitive traits such as perseverance and emotional stability (Baker, Gruber and Milligan, 2008 ${ }_{[79]}$; Baker, Gruber and Milligan, 2015[80] $)$. This result has been shown to be a consequence of negative effects on children who gain access to subsidised childcare at an early age, while there are benefits from access to universal childcare on developmental scores for those that are above three years of age (Kottelenberg and Lehrer, 2017[81]). Beneficial development effects were most likely among children from single-parent households, particularly the most disadvantaged (Kottelenberg and Lehrer, 2017 [81] $)$.

Mixed outcomes for child development have been ascribed to a lower quality of care by some providers. Quality in non-profit public garderies was "good or excellent" for $45 \%$ of children and "inadequate" for only $4 \%$; by contrast, quality in full-fee, for-profit garderies was "good" for $10 \%$ of children and "inadequate" for 36\% (Fortin, 2018 ${ }_{[76]}$ ). Quality care has been shown to deliver positive outcomes: non-profit public garderies generate positive cognitive, health and behavioural results on average; they have delivered large reductions in the risk of poor cognitive or behavioural development for children from low-income families and more modest, but still significant, reductions for children from middle- and high-income families (Laurin et al., 2015 [82]).

Extending the provision of kindergarten to two years in provinces and territories where this is not already the case would be the simplest means to ensure sufficient access to preprimary education. The kindergarten system in Canada compares well against other OECD countries in terms of availability to a large proportion of the population, low pupil-teacher ratios and investment per child (Conference Board of Canada, 2017 ${ }_{[83]}$ ). Universal coverage, as in the kindergarten system, has the advantage of aiding socio-economic mixing and lifting quality (Fortin, 2016 $6_{[77]}$ ). 
Figure 17. Few Canadian children attended early childhood education for two years or more Share of 15-year-old students, by socio-economic background, ${ }^{1} 2015$

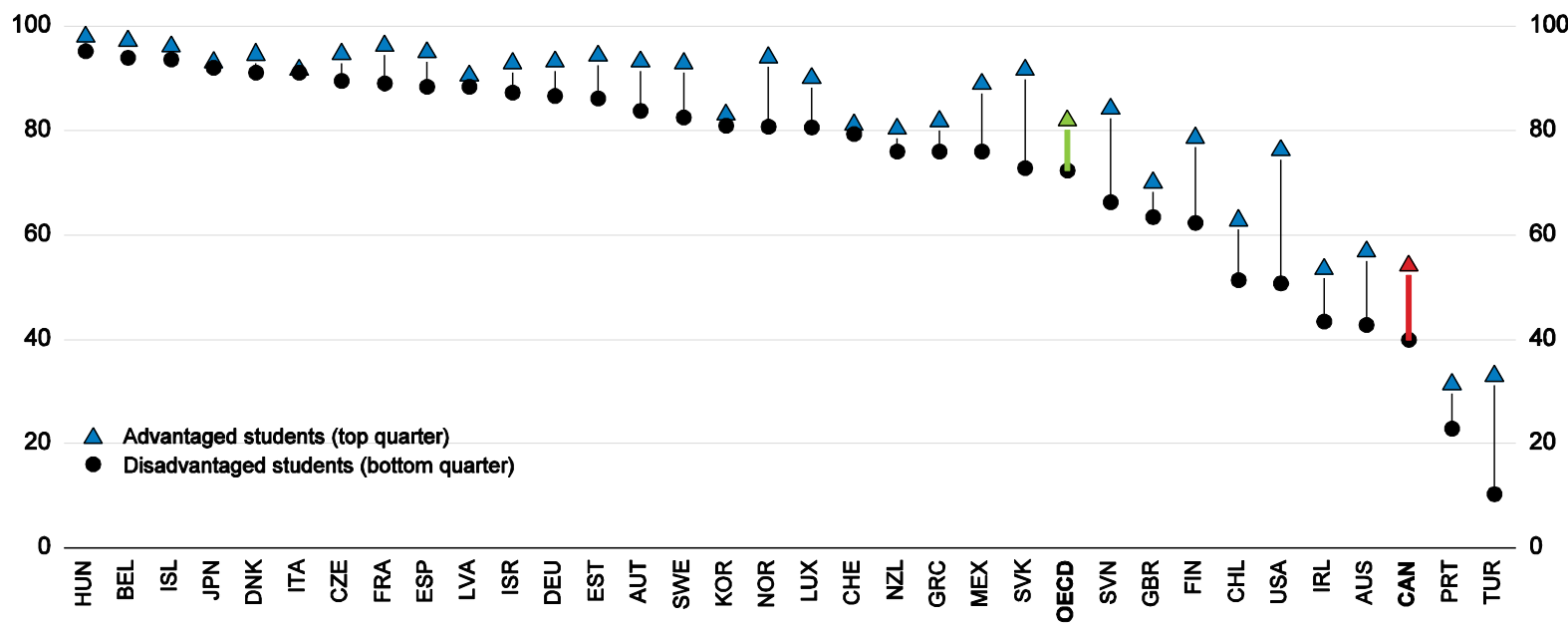

1. Measured using the PISA index of economic, social and cultural status.

Source: OECD (2018), Engaging Young Children: Lessons from Research about Quality in Early Childhood Education and Care, Starting Strong, Figure 1.3.

Provision of ECEC for children three and under should also be expanded to give women the opportunity to increase their labour force participation, but adequate quality of care needs to be ensured. The brain sensitivity of highly important developmental areas, such as emotional control, social skills, language and numeracy, peak in the first three years of a

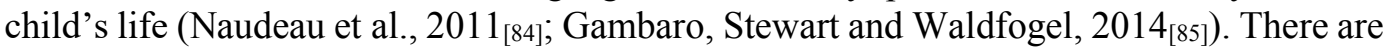
greater risks of negative effects on child development from access to low-quality childcare at a younger age, as demonstrated in Québec (Box ). The Québec example is consistent with international research showing that while high-quality ECEC is beneficial for children's early development and subsequent school performance, low-quality ECEC can be associated with detrimental effects on development and learning (OECD, 2018 [86]).

To maximise net benefits, ECEC for young children should be affordable for all, with some means testing to reduce the fiscal cost and benefits targeted at those most in need. This could be achieved through public provision of care, subsidies for childcare providers or refundable tax credits. Tax deductions, such as those available through the federal Child Care Expense Deduction, are not well-targeted as they provide the greatest benefits to those with higher incomes. As noted above, child-development benefits from high-quality ECEC are greatest among children from disadvantaged families. The fiscal payback from increasing access to affordable childcare will be largest where people returning to work face high effective tax rates (for example, where they lose entitlement to welfare payments) and where improved attachment to the workforce continues to boost their probability of being in work after their children start school. Both of these effects are concentrated among low-income earners. But ensuring mid- and high-income families can access childcare is also important: increasing labour force participation of women with high educational attainment offers the greatest payoff in terms of boosting productivity (Petersson, Rodrigo and Ishi, $\left.2017_{[87]}\right)$.

Investment should be directed towards achieving high-quality child development outcomes, rather than the simple creation of places. This requires effective oversight and regulation of childcare services as information failures mean that parents are not wellequipped to assess ECEC quality ex ante. The capacity of regulatory bodies needs to 
expand in line with or even ahead of increases in service provision to ensure that quality standards are maintained or improved. Effective regulation of family daycare is particularly important, as quality is generally lower in family daycare and regulation that includes higher qualification requirements is associated with better interactions for children (OECD, $\left.2018_{[86]}\right)$.

Monitoring performance and the development of a professionalised workforce are key factors in delivering quality ECEC. Data and monitoring can be a powerful lever to encourage ECEC quality, including through informing measures to achieve improvement, and implementation of quality monitoring and rating improvement systems internationally is associated with better staff-child interaction. There is room for improvement here as Canada lacks consistent national data on child care costs, expenditures, quality of service, child care use patterns and child outcomes. Teacher qualifications and lower child-staff ratios/group sizes (particularly for younger children) are also associated with better staff-child interaction, but the evidence is inconclusive regarding effects on child learning and development. Staff years of experience are not a good predictor of quality. There are, however, clear links between in-service training or professional development and more positive child development (OECD, 2018 $\left.8_{[86]}\right)$. Workforce development and monitoring performance should go hand-in-hand: a culture should be established among educators where it is the norm to know the impact that ECEC programmes are having on children's learning and development (Torii, Fox and Cloney, 2017 ${ }_{[88]}$ ). Korea's Appraisal for Kindergarten Teacher Professional Development is a valuable example where self, peer and parent evaluation are used to target training and professional development activity (OECD, 2015 $\left.5_{[89]}\right)$.

Improving early childhood education also offers inclusiveness gains for the other groups studied in this paper. Early childhood education reduces the barriers to further education and finding employment faced by children from low socioeconomic groups. Early-life intervention is also critical to increase future equality among adult Canadians, as inequality cumulates over the life cycle (OECD, 2017 $\left.{ }_{[90]}\right)$.

\section{Remove barriers to women's participation in computing and engineering}

Women are less likely than men to be employed in occupations using scientific, technology, engineering and mathematics (STEM) skills. Since these disciplines are typically highly paid, this contributes to the gender wage gap and is likely to continue to do so given projections of strong growth in demand for these skills. Just under half (45\%) of graduates in science, maths and computing are female, which puts Canada in the top dozen OECD countries for gender equality in STEM education (OECD, 2017 $7_{[35]}$. However, women make up only around a quarter of people employed in professional scientific occupations (Moyser, 2017 [36]).

There are a large number of Canadian women with the ability and foundational knowledge to study and work in STEM fields. In the province of Ontario, for example, the gender gap in the number of students that meet prerequisites for STEM programmes is small (Card and Payne, 2017[91]). At age 15 there is no statistically significant difference in mean proficiency in science between Canadian boys and girls and only a small gap (around onethird of a year of progress) in mean mathematics proficiency (OECD, 2016 [92] $_{\text {). }}$.

There is substantial variation in women's participation in fields using STEM skills. In some, it has increased strongly, notably in medicine where the majority of active physicians under 45 are now female (Canadian Medical Association, 2017 [93]). Women also comprise 
the majority of bachelor-level graduates in science and mathematics, but a much lower share in computing and engineering (Figure 18).

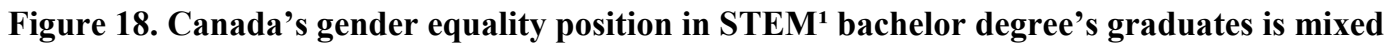
Female shares in per cent, 2015 data

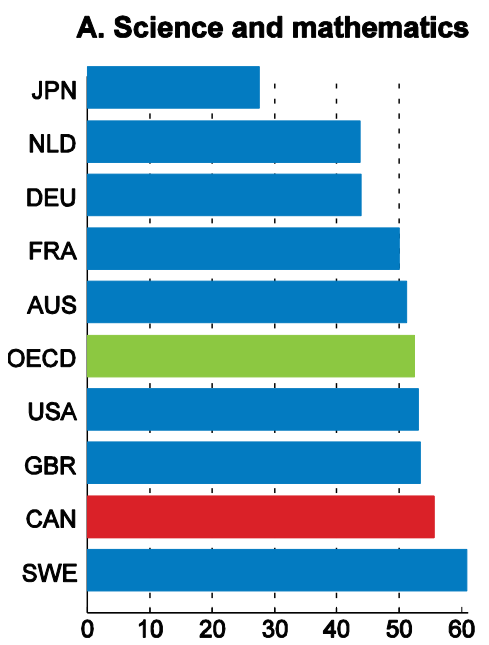

B. $I C T^{2}$

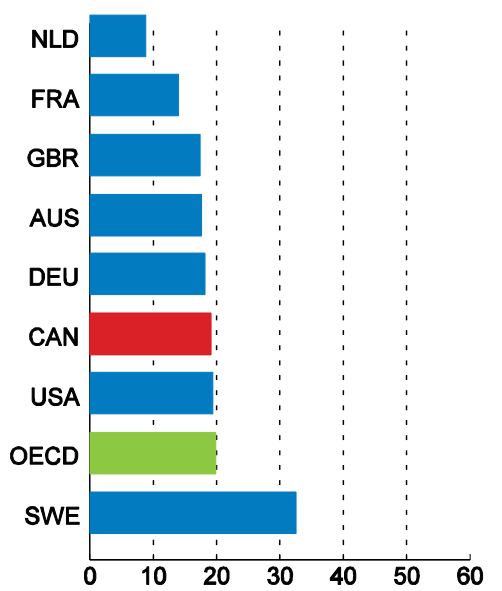

C. Engineering

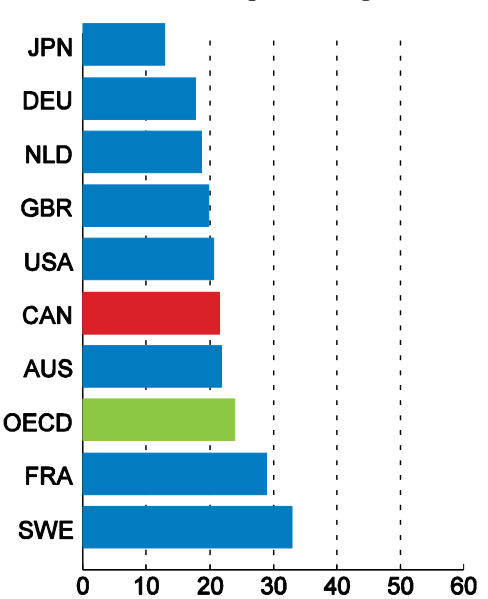

1. Science, technology, engineering and mathematics.

2. Information and communication technologies.

Source: OECD (2017), Education at a Glance database.

Gender differences in career preferences start young, with just 3\% of Canadian girls and $19 \%$ of Canadian boys at age 15 planning a career in engineering and computing, a gap that exceeds the OECD average (OECD, 2016 $\left.{ }_{[92]}\right)$. This compares with $30 \%$ of girls and $12 \%$ of boys planning a career in health services. To some extent these differences in preferences reflect different interests: on average women have a greater preference for work that is altruistic and people-oriented, compared with men's preference for "thing-oriented" work (Kahn and Ginther, 2018[94]). But preferences are also likely to reflect barriers to female involvement such as gender stereotypes, workplace culture, lack of role models and risk aversion.

High female drop-out rates in male-dominated fields contribute to the low share of female professionals. In the United States, for example, women are less likely than men to start in computer science jobs after completing their degrees and much more likely to leave those jobs (Ginther and Rosenbloom, 2015 $5_{[95]}$ ). The exit rate for women compared to men is significantly higher from engineering, as in other male-dominated fields. Hunt (2016 [96] $)$ concludes that the explanation is thus likely to lie in a lack of mentoring and networks or discrimination by managers and co-workers, rather than the nature of engineering work itself. Since differences in preferences are driven by gender norms, Xie and Shauman $\left(2003_{[97]}\right)$ argue that the gender gap in parenting responsibilities is a critical barrier to the further advancement of women in science and engineering.

There are a number of initiatives underway to promote greater participation of women in STEM. For example, the PromoScience Program funds organisations that offer children of kindergarten or school age opportunities to participate in activities known to build engagement, interest, skills and knowledge in STEM. The ChooseScience digital campaign, launched in February 2017, offers resources for parents and teachers to encourage young women to consider careers in STEM. The federal government also 
committed to tying increased funding for researchers in its 2018 Budget to objectives and conditions that will ensure greater diversity among the researcher population.

A number of further measures should be taken to remove barriers to women's participation in STEM, beginning with better information on labour market outcomes, as discussed in more detail in relation to youth below. The Canada-United States Council for Advancement of Women Entrepreneurs and Business Leaders (2018 $\left.{ }_{[98]}\right)$ has recommended the creation of an online STEM portal to provide further information on STEM career paths, programs, learning tools and case studies. Teachers and curricula should focus on helping students, particularly girls, to overcome their anxiety towards mathematics and to develop a "growth mindset" that emphasises the value of effort rather than natural ability (Kahn and Ginther, 2018[94]). Programmes should be aimed at young children and their parents, carers and teachers to address unconscious biases and stereotyping of girls' interests and abilities in STEM subjects. Expectations and role models are important (BIAC, 2018[99]). Alleviating the burden from gender disparities in childcare responsibilities on women and shifting cultural norms through more parental leave by fathers and better access to childcare may therefore also help.

\section{Improving well-being for single mothers}

Single mothers face particular challenges. Average family incomes for lone mothers were less than half of those for couples with children in 2015 after adjusting for family size, while their average net worth in 2016 was a third of couple families' and half of lone fathers' (Fox and Moyser, 2018 $\left.{ }_{[100]}\right)$. The latest internationally comparable data from 2014 show that single parents in Canada had comparatively high rates of relative poverty (Figure 19). Recent reforms are likely to have reduced poverty among single parents, although data are not yet available to assess progress. The most important of these was the 2016 introduction of the Canada Child Benefit, which helped single parents in particular, as they did not lose from the simultaneous removal of income-splitting provisions in the tax code. There have also been increases in childcare funding and minimum wage increases.

In 2016 only $56 \%$ of single mothers of children under six were employed (Statistics Canada, $\left.2017_{[8]}\right)$. Employment is somewhat higher at $68 \%$ for single mothers of children under 16, which is around the OECD average, although definitional differences prevent a like-for-like comparison (OECD, 2017 ${ }_{[66]}$; Statistics Canada, 2017 $7_{[8]}$ ). Low-income single mothers have muted incentives to find work, as they face high participation tax rates, as mentioned above.

A number of complementary reforms would help to continue to address high rates of poverty among single mothers. The emphasis should be on achieving sustainable improvements in well-being and reducing the risk of poverty traps by removing barriers to employment among single mothers, as employment is associated with a significant reduction in the risk of poverty for single-parent households (Maldonado and Nieuwenhuis, $\left.2015_{[101]}\right)$. 
Figure 19. Poverty rates of employed and unemployed single-parent families are high

Share with income after taxes and transfers below 50\% of the median, 2016 or latest year available

\section{A. Single parent employed}

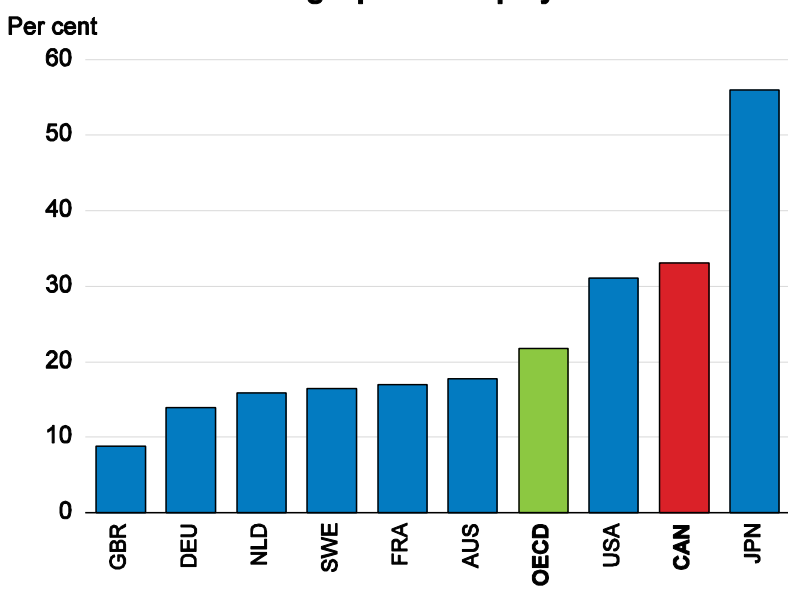

B. Single parent unemployed

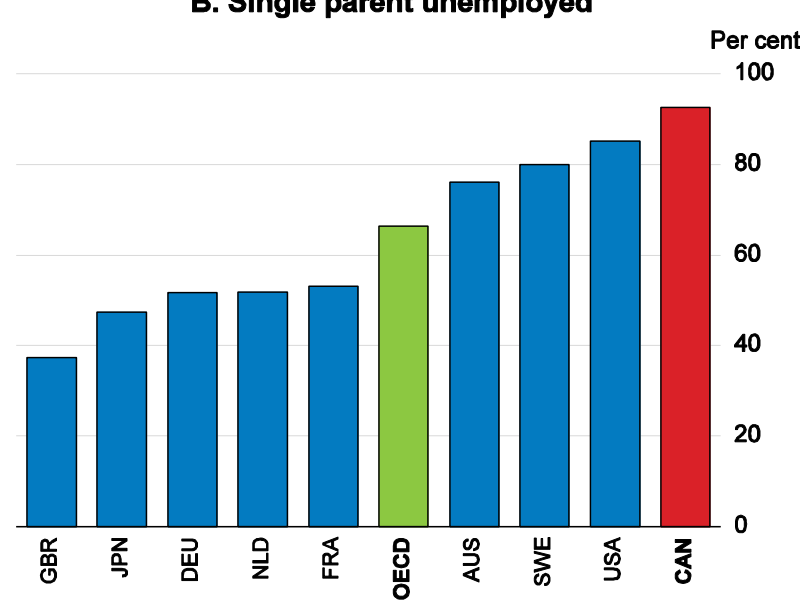

Source: OECD (2017), Income Distribution database, http://www.oecd.org/els/soc/income-distributiondatabase.htm.

In-work tax benefits should be made more generous for low-income single parents to tackle high participation tax rates, with higher payments under the Canada Workers Benefit a good start in this regard. Targeting in-work benefits at single parents is an effective way to address needs. More generous in-work benefits than the current WITB for lone parents were included in trials under Canada's Self-Sufficiency Project, and the evidence established that this can be a cost-effective way to increase employment and incomes (Immervoll and Pearson, 2009 $[17]$ ). Expanding active labour market spending has the potential to complement more generous in-work benefits by overcoming barriers to employment among single parents; active labour market policy has been shown to have bigger effects for women than men (Bergemann and Van den Berg, 2008 ${ }_{[102]}$ ). Better access to high-quality affordable childcare will also be helpful: the poverty rate among singlemother families in Québec fell from 36\% to 22\% following the introduction of low-cost childcare and the associated increase in workforce participation (Fortin, Godbout and StCerny, 2013 $\left.{ }_{[78]}\right)$.

\section{Promoting female entrepreneurship}

Canadian women are more actively involved in entrepreneurship than their counterparts in most OECD countries, and the number of self-employed women has more than doubled over the last 30 years. While $38.8 \%$ of the self-employed are women (Moyser, 2017 ${ }_{[36]}$ ), only $15.5 \%$ of SMEs were majority-owned by females in 2011, compared with about two thirds that were owned by males (Industry Canada, 2015 $[103]$ ). Majority female-owned SMEs tend to be smaller, to grow more slowly than their male-owned counterparts and less likely to export, and are also under-represented in (relatively high-growth) high-tech manufacturing and knowledge-intensive sectors.

There are a number of barriers to Canadian female entrepreneurship including lack of management experience, role models, access to finance and large buyers, as well as the low share of women in STEM disciplines (Canada-United States Council for Advancement of Women Entrepreneurs and Business Leaders, $2018_{[104]}$; OECD, $\left.2017_{[105]}\right)$. Removing these barriers is important to increase inclusiveness of opportunity to benefit from economic growth and to offer more flexibility in work. The federal government has given priority to 
supporting women entrepreneurs through the Women Entrepreneurship Strategy, which has the potential to bring together scattered existing programmes and build institutional consensus on the policies required to narrow entrepreneurship gaps. The Strategy includes CAD 1.4 billion in new financing for women entrepreneurs through the Business Development Bank of Canada and CAD 250 million through Export Development Canada, both of which are promising initiatives given evidence that women-specific loan guarantees create more jobs than mainstream programmes (Western Economic Diversification Canada, 2014 $[106])$. Additional funding for gender-disaggregated data on entrepreneurship will help build the evidence base for policy making and should incorporate information on obstacles and programme use. The Strategy also includes funding to implement regional female entrepreneurship initiatives, aims to increase the proportion of women entrepreneurs participating in federal procurement and includes reforms to federal innovation programmes to increase the participation of underrepresented groups in the innovation economy.

Other steps to address barriers to women's entrepreneurship include ensuring skillbuilding, incubator and accelerator programmes are targeted at women by providing female role models, expanding the provision of microfinance for women entrepreneurs, removing unwarranted restrictions on eligibility for part-time entrepreneurs to public enterprise support programmes and extending successful western Canadian women's entrepreneurship programmes to the rest of the country. Good practice examples of European inclusive entrepreneurship initiatives illustrate the importance of defining clear objectives and targets for policy intervention, targeting outreach to engage underrepresented groups, using competitive mechanisms to target intensive support at those with the potential to succeed, and collecting data on outcomes to learn from experience $\left(\mathrm{OECD} / \mathrm{EU}, 2016_{[107]}\right)$.

\section{Inclusiveness for youth}

The majority of young Canadians are well-equipped to manage transitions between school, post-school education and work. More than 60\% of Canadians aged 25-34 in 2016 had completed tertiary education $\left(\mathrm{OECD}, 2017_{[108]}\right)$. This is the second highest share in the OECD behind Korea, boosted by Canada's large college sector. The share of 19 year-olds enrolled in a post-secondary education programme increased steadily from 2001 to 2014 among youth from all families, but particularly among those at the bottom of the income distribution (Frenette, 2017 ${ }_{[109]}$ ). However, post-secondary education attendance remains much lower for those from low-income families, due primarily to differences in academic achievement and parental expectations (Frenette, 2007 $[110]$ ).

\section{A substantial minority of Canadian youth are at risk of becoming detached from the labour market}

Around $15 \%$ of Canadian youth aged 20 to 24 were not in employment, education or training (NEET) in 2016 (Figure 20). While this is a slightly lower share than the OECD average, it still indicates a substantial number of youth at risk of not developing the skills and experience needed for success in the labour market of the future.

The unemployment rate for youth in Canada is around double that of the working-age population as a whole, consistent with historical experience and just below the OECD average. Recent labour market strength has reduced youth unemployment to below $11 \%$, only the third time in the last 40 years that this has been achieved (the others being in 1989- 
90 and 2007-08) (Statistics Canada, 2017 ${ }_{[8]}$ ). Unemployment remains elevated for the declining share of youth who have not finished secondary school (Figure 21).

Figure 20. Slightly fewer youth than average are not in employment, education or training As a percentage of those in the same age group, 2016 or latest available year

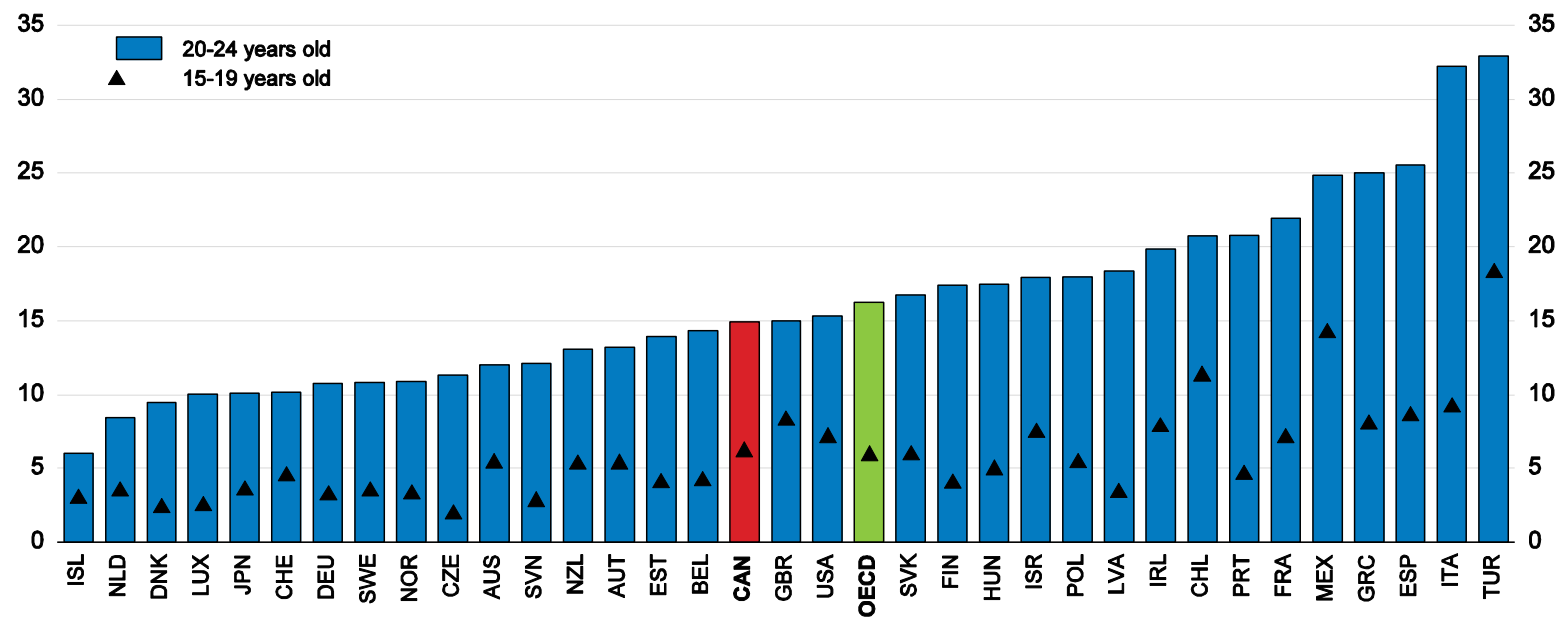

Source: OECD, Education at a Glance: Transition from School to Work database.

Figure 21. Youth unemployment is high for those who do not complete high school Unemployment rate for 15-24 year-olds

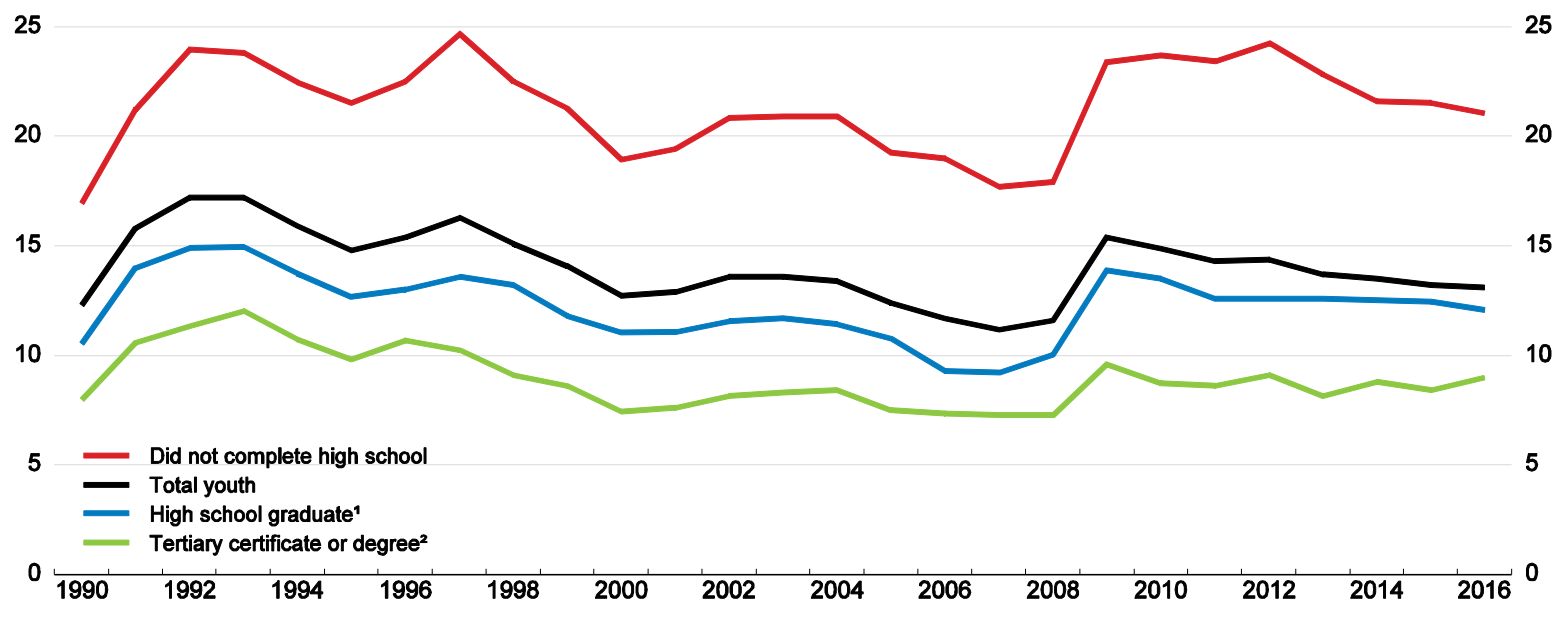

1. Graduated from high school and/or started some postsecondary studies.

2. Have a postsecondary certificate or a university degree.

Source: Statistics Canada, Labour Force Survey, Table 282-0004.

\section{Earnings for most young men are yet to recover from earlier declines}

Real median annual wages and salaries for men aged 28 to 29 were lower in 2015 than they had been in the late 1970s, with earnings growth since the mid-1990s insufficient to make up for earlier falls (Morissette, $2018_{[111]}$ ). The earlier fall in earnings was larger for those further down the income distribution and for those with low educational attainment (Beaudry and Green, 2000 [112] $)$. By contrast, real wages for those at the $90^{\text {th }}$ percentile of the earnings distribution have increased. As in several other OECD countries (Flores and 
Geppert, $2018_{[113]}$ ), successive cohorts of men have failed to "catch up" with the wages of their predecessors, so that lifetime earnings for those in the bottom half of the income distribution have fallen. Median cumulative earnings over the first 12 years in the workforce were $9 \%$ lower for those who entered the workforce in 2004 compared with 1978, with even greater falls for those earning below the median (Morissette, 2018 [111]).

Women also experienced a decline in median earnings during the $1980 \mathrm{~s}$, but declines were shallower and had more than recovered following wage growth in the late 1990s and 2000s. Weak earnings growth between the late 1970s and the mid-1990s was not limited to youth, with a similar pattern observed in equivalised household median incomes among all Canadians (Corak, 2016 $\left.6_{[14]}\right)$.

\section{Skills development should continue to be prioritised}

Young people's science, literacy and numeracy skills are generally strong, but comparison of two surveys from 2003 and 2012 indicates that skill levels have declined recently among Canadians aged 16 to 24 (Mahboubi, 2017 $[115]$ ). The gap between literacy and numeracy skills of those aged 20-24 who have a tertiary qualification (or are enrolled in tertiary education) and those who do not is among the upper half of OECD countries (Figure 22). Across all Canadians aged 16-24, around one in six youth have skills at or below the lowest threshold according to the OECD's PIAAC results. This is comparable to the OECD average but well behind leading OECD countries such as Finland, Japan, Korea and the Netherlands, where less than one in ten people aged 16-24 have such low literacy and numeracy skills.

Figure 22. Skills gaps between those with and without tertiary education are large Difference in proficiency for young adults aged 20 to 24

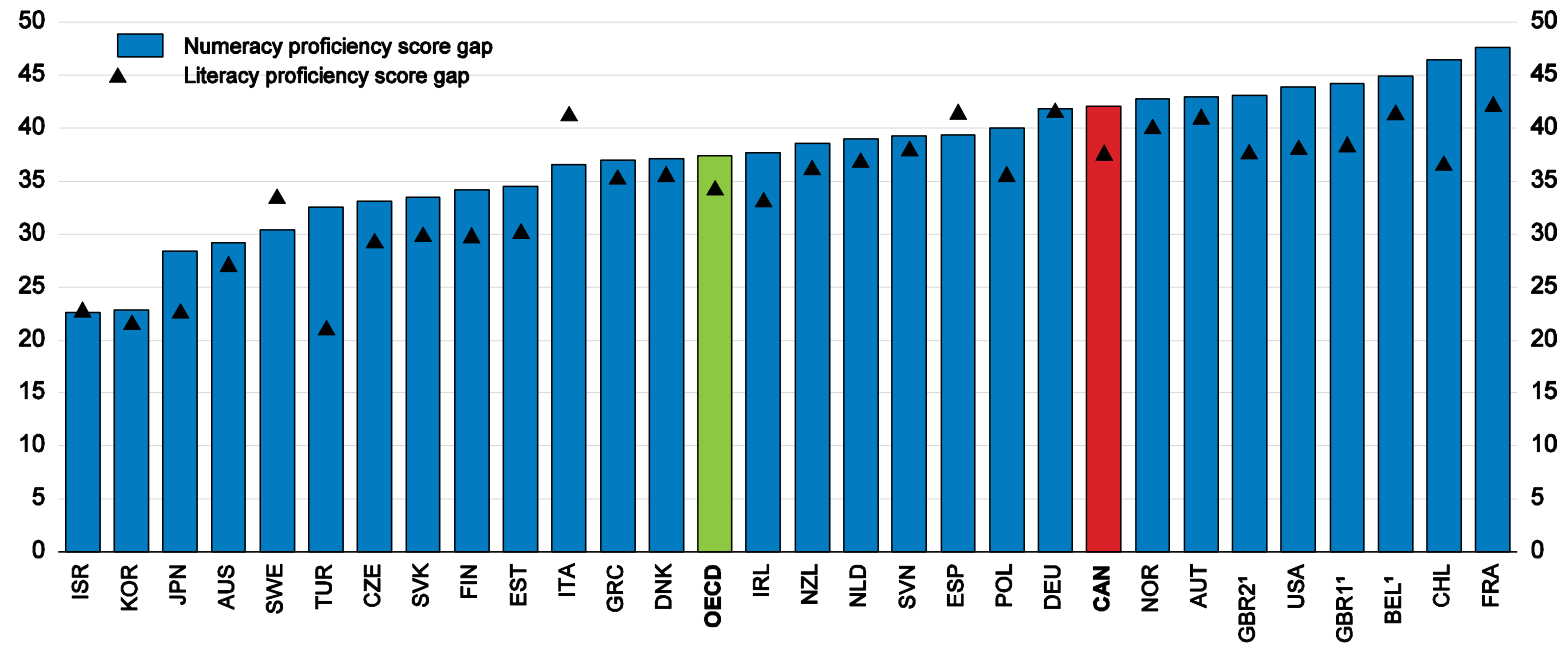

1. $\mathrm{BEL}=$ Flanders; GBR $1=$ England; and GBR2 $=$ Northern Ireland.

Source: OECD (2016), Skills Matter: Further Results from the Survey of Adult Skills, Annex A, Tables A3.4 (L) and $\mathrm{A} 3.4(\mathrm{~N})$.

The existence of a small but significant minority of youth with poor basic skills presents a problem for future workplace needs, where lifelong learning is likely to be increasingly important. Adult learners need the literacy, numeracy, communication and other essential skills to be able to retain learning and apply it. Canada currently sits just above the OECD average on participation in formal and informal adult learning (OECD, 2017 $\left.{ }_{[5]}\right)$. Declining skill levels are also a problem given the increased demand for those with high skills due to 
skill-biased technological change. Between 1995 and 2015, the share of Canadian jobs requiring high skills expanded by $4.3 \%$, while those requiring middle-level skills contracted by $6.2 \%$ and those requiring low skills expanded by $1.8 \%\left(\mathrm{OECD}, 2017_{[116]}\right)$. A similar pattern of job polarisation was experienced in almost all OECD countries and has contributed to lower earnings at the bottom of the distribution, as the disappearance of midlevel jobs has reinforced competition for lower paid jobs. In a globalised, knowledgeintensive economy where technological change is continually reshaping the labour market, individuals with low educational attainment and skills are being increasingly penalised.

Government policy should continue to promote development of basic skills through school and adult education programmes, given the clear links between skills and workplace outcomes as well as the decline in skills among the current youth cohort. The government provided additional funding in its 2018 Budget to support doubling of the number of job placements funded under the Canada Summer Jobs program, launched the Student WorkIntegrated Learning Program to help post-secondary students in STEM and business programs get work experience, and is currently developing a renewed Youth Employment Strategy. If implemented well, these initiatives could bring much-needed improvement in how skills are used in the workplace and the alignment between work force skills and business' needs. Support should be targeted at those at greatest risk of becoming NEET and potentially falling into long-term inactivity. Outcomes from raising the compulsory schooling age to 18 in Manitoba, Ontario and New Brunswick should be studied further to ascertain whether benefits from earlier increases documented by Oreopoulos $\left(2006_{[117]}\right)$ have been repeated. If they have, other provinces should follow suit, along with measures to diversify curricula to meet the needs of a broader student population at upper-secondary level. In particular, upper-secondary VET programmes are underdeveloped, which complicates labour market entry and restricts further schooling for young people who are not interested in pursuing higher education.

\section{Improve labour market information and dissemination}

Workers and their jobs are generally well matched, but there is a high prevalence of qualifications mismatch (Figure 23). Over-qualification has a significant impact on wages, even after adjusting for skills, and Canada is among the nations in the OECD's Survey of Adult Skills with the largest associated wage penalties (OECD, 2016 $\left.{ }_{[118]}\right)$. The prevalence of qualifications mismatch raises questions about the capacity of the Canadian education system to adapt to future workplace needs, which have the potential to change rapidly with advances in digitalisation, notably artificial intelligence.

Fragmented data on labour market outcomes undermine labour market matching by failing to provide clear signals to young Canadians regarding the career prospects from different types of post-secondary education. When they see little connection between their studies and future employment, it becomes easier for students to disengage or drop out. There is inconsistency in labour market data sampling and terminology across jurisdictions, for example poor correspondence between Statistics Canada's Economic and Employment Insurance Regions and Employment Ontario regions (OECD, 2014 ${ }_{[119]}$; Advisory Council on Economic Growth, $\left.2017_{[120]}\right)$ ). Labour market information is available across multiple sites, hard to find and challenging to interpret and apply to stakeholders' specific needs (Highly Skilled Workforce Expert Panel, 2016 ${ }_{[121]}$ ). In some places, for example in Saskatchewan, there is a lack of location-specific labour market information $\left(\mathrm{OECD}, 2016_{[122]}\right)$. It was estimated that there 
Figure 23. Qualifications mismatch ${ }^{\mathbf{1}}$ is large

Percentage of mismatched workers, by type of mismatch, 2012 and $2015^{2}$

\section{A. Qualifications mismatch}

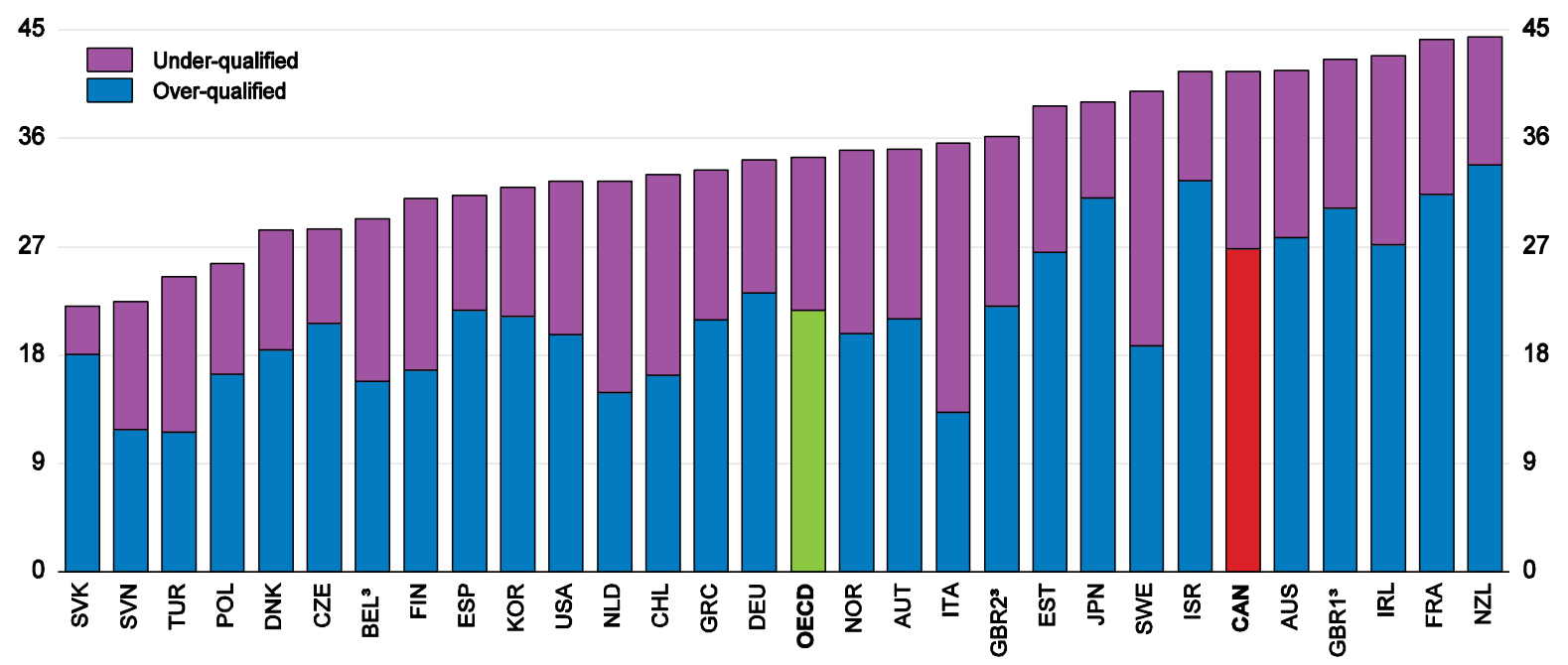

\section{B. Literacy skills mismatch}

36

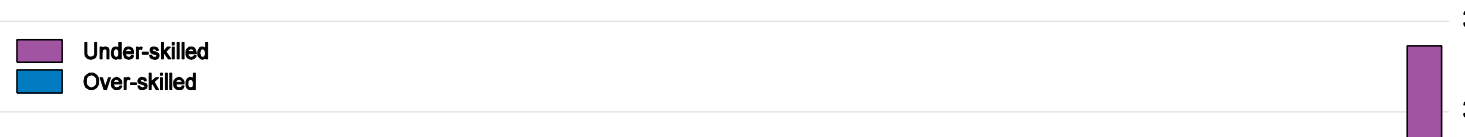

30

24

18

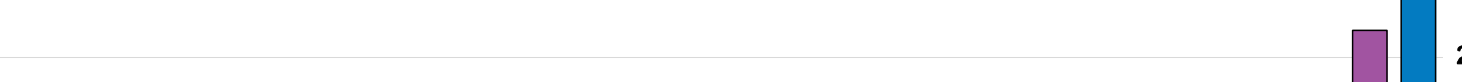

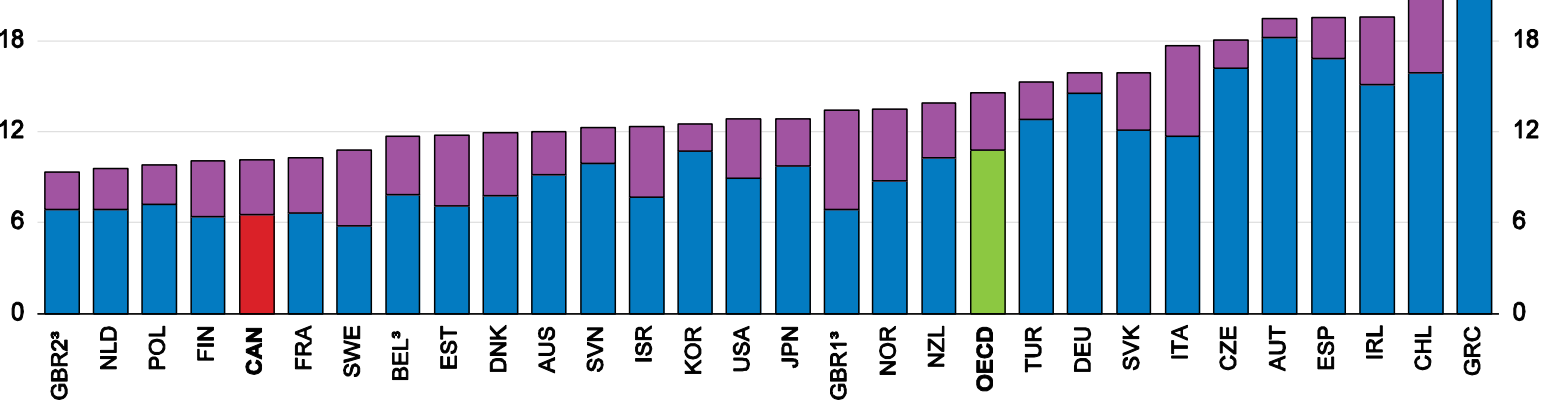

1. Qualifications mismatch occurs when a worker has a higher or lower level of qualification than is required for his/her job. Skills mismatch occurs when a worker's skills are higher than the 90th percentile or lower than the 10th percentile of workers with self-reported well-matched skills.

2. Data correspond to 2012 for countries participating in the first round of the Survey of Adult Skills: Australia, Austria, Belgium, Canada, Czech Republic, Denmark, Estonia, Finland, France, Germany, Ireland, Italy, Japan, Korea, Netherlands, Norway, Poland, Slovak Republic, Spain, Sweden, United States and United Kingdom. Data correspond to 2015 for countries participating in the second round of the Survey of Adult Skills: Chile, Greece, Israel, New Zealand, Slovenia and Turkey.

3. Data indicated as Belgium correspond to Flanders; GBR $1=$ England and GBR2 $=$ Northern Ireland.

Source: OECD (2016), Skills Matter: Further Results from the Survey of Adult Skills, Annex A, Tables Chapter 5 - Table A5.7; OECD Survey of Adult Skills (PIAAC) database (2012 and 2015).

were over 10000 community-based organisations delivering career-development services across Canada in the early 2000s, which brings services closer to end-users but can also result in service fragmentation $\left(\mathrm{OECD}, 2004_{[123]}\right)$. Better labour market data would help these organisations to function more effectively by providing timely and relevant information on job opportunities and how these are linked to specific courses of study. 
Fortunately, there are a number of initiatives underway to improve labour market information, including the creation of a new national Labour Market Information Council, the Education and Labour Market Longitudinal Linkage Platform announced in the 2018 Budget, the federal government's Job Bank portal (for which a new mobile application was recently launched) and provincial-level initiatives such as Ontario Job Futures. The new Future Skills organisation, scheduled for launch in spring 2018, will also have a role in identifying skills required by Canadian employers and workforce trends. The objectives of new federal and provincial initiatives should be clearly defined to avoid duplication and overlap.

The formation of the Labour Market Information Council is a key step in the provision of better labour market information across Canada. Having a single national body responsible for publishing detailed labour market information, with full support from the provinces and territories, would eliminate regional gaps while improving consistency and accessibility. The Council should build on the existing federal Job Bank website, which provides a national source for career information, job search and skills matching, exploring new methods to bring together substantial data available from provinces and post-secondary institutions. Additional information should include the number of students projected to graduate by detailed post-secondary programme, the number of apprentices per trade, and employment and salary outcomes by detailed region, qualification and institution, as well as qualitative analysis on the in-school experience of students and how useful they find their programme for workplace preparation. Similar data has been made available in other OECD countries, for example in Spain where the government in 2014 made data available on labour market outcomes of graduates by degree and institution (OECD, 2014 ${ }_{[124]}$ ).

\section{Leverage benefits from vocational education and training}

Employability of youth can be boosted by combining learning with work experience wherever possible, as this improves job-related skills and enhances engagement by demonstrating practical application of classroom skills (OECD, 2017 $\left.{ }_{[5]}\right)$. There are two main strands to postsecondary vocational education and training in Canada: apprenticeships and college programmes. Vocational education is a provincial/territorial responsibility, and each such jurisdiction has its own designated apprenticeship system. This can create problems of consistency and recognition across the country, although federal government support for certification through the Red Seal Programme has helped to establish common standards.

Better labour market information has the potential to address the often poor reputation of vocational education and training by correcting misconceptions about employment outcomes from specific types of vocational training. Governments should also encourage further development of pathways from vocational education to advanced diploma and degree programmes that are certified and recognised nationally, which has the potential to improve the status of and career opportunities from vocational education (Álvarez-Galván et al., $\left.2015_{[125]}\right)$.

Vocational education systems in Ontario (in particular) and Québec are relatively flexible and accommodate the needs of workers well compared to other OECD jurisdictions $\left(\mathrm{OECD}, 2014_{[126]}\right)$. While around half of all apprentices fail to complete their apprenticeships, many continue to work in relevant trades where certification is not mandatory (OECD, 2014 $\left.{ }_{[119]}\right)$. Compared with many other OECD countries, it is less common for consortia of employers to offer apprenticeships jointly, which makes it more difficult for youth to find apprenticeships. 
For youth at risk of being NEET, pre-apprenticeship training can be a valuable way to tip the balance between costs and benefits for employers who take them on for work-based training (Kis, 2016 $\left.{ }_{[127]}\right)$. A new Pre-Apprenticeship Program announced in the 2018 federal Budget will target people who are currently underrepresented in the trades, including women (supporting a number of other new programmes to boost participation of women in the trades), youth, Indigenous Peoples, new immigrants and people with disabilities. One issue that could be addressed through the Program is educational institutions' lack of certainty regarding pre-apprenticeship training programmes, as they generally need to reapply for funding each year, which undermines long-term planning and programme development. Further support services, such as marketing, information and guidance could be provided to local employers wishing to take on apprentices, particularly SMEs (OECD, $\left.2014_{[119]}\right)$.

Also critical is priority access to other forms of training and assistance to give NEET youth the skills they need to be more employable. This is done through the Youth Employment Strategy at the federal level and by provincial initiatives such as the Ontario Youth Jobs Strategy and Youth Employment Centres (carrefours jeunesse-emploi) in Québec. The overlap between federal and provincial measures means that strong coordination is essential. More intensive programmes should be targeted towards the small group of youth that face multiple employment barriers. Tying social assistance to participation in youthspecific training or employment programmes, as in Sweden, could boost participation (Steeve et al., 2017 $[128]$ ).

\section{Inclusiveness for seniors aged 55 and above}

Canada's retirement income system (Table 3) shapes employment incentives for older Canadians as well as income adequacy for retirees. The relative poverty rate for those aged 65 or older is less than that of the entire population, lower than in several comparable countries and a substantial step-down from a much higher poverty rate for those aged 51 to 64 (Figure 24). However, the poverty rate for those aged 65 or over has risen from record low levels in 1995 due to the failure of minimum public pensions (indexed to the CPI) to keep up with median wage growth, declining rates of employer pension plan coverage and inadequate retirement savings (Shillington, 2016 $\left.{ }_{[129]}\right)$. Poverty rates are much higher among singles and recent immigrants, particularly those who have not resided in Canada long enough to qualify for public first-pillar (OAS) payments. 
Table 3. A description of Canada's retirement income system

\begin{tabular}{|c|c|c|}
\hline & Key programmes & Key characteristics \\
\hline Pillar 1 & $\begin{array}{l}\text { Old Age Security (OAS), Guaranteed } \\
\text { Income Supplement (GIS) and smaller } \\
\text { federal and provincial supplement } \\
\text { programmes }\end{array}$ & $\begin{array}{l}\text { Financed from general revenue and publicly administered. } \\
\text { Benefits are income-tested (although OAS benefits are only withdrawn } \\
\text { with income above CAD } 79510 \text { ) and based on duration of residence. } \\
\text { OAS and GIS available from age } 65 .\end{array}$ \\
\hline Pillar 2 & $\begin{array}{l}\text { Canada Pension Plan (CPP) and } \\
\text { Québec Pension Plan (QPP) }\end{array}$ & $\begin{array}{l}\text { Mandatory social insurance administered by federal and provincial } \\
\text { governments, with earnings-related contributions and benefits } \\
\text { Full benefit at age } 65 \text {. Available from age } 60 \text {, with payment rates } \\
\text { decreasing by } 8.4 \% \text { per year with early take-up. Payment rates increase } \\
\text { by } 7.2 \% \text { per year after age } 65 \text { for deferral up to age } 70 \text {. }\end{array}$ \\
\hline Pillar 3 & $\begin{array}{l}\text { Workplace (registered) pension plans } \\
\text { Registered Retirement Savings Plans } \\
\text { Tax Free Savings Accounts }\end{array}$ & $\begin{array}{l}\text { Privately administered } \\
\text { Voluntary for employers and/or individuals } \\
\text { Regulated and tax-supported }\end{array}$ \\
\hline
\end{tabular}

Source: Adapted from B. Baldwin and R. Shillington (2017), Unfinished Business: Pension Reform in Canada, IRPP.

Figure 24. Canada's relative poverty rate after taxes and transfers is low for the over-65s ${ }^{1}$

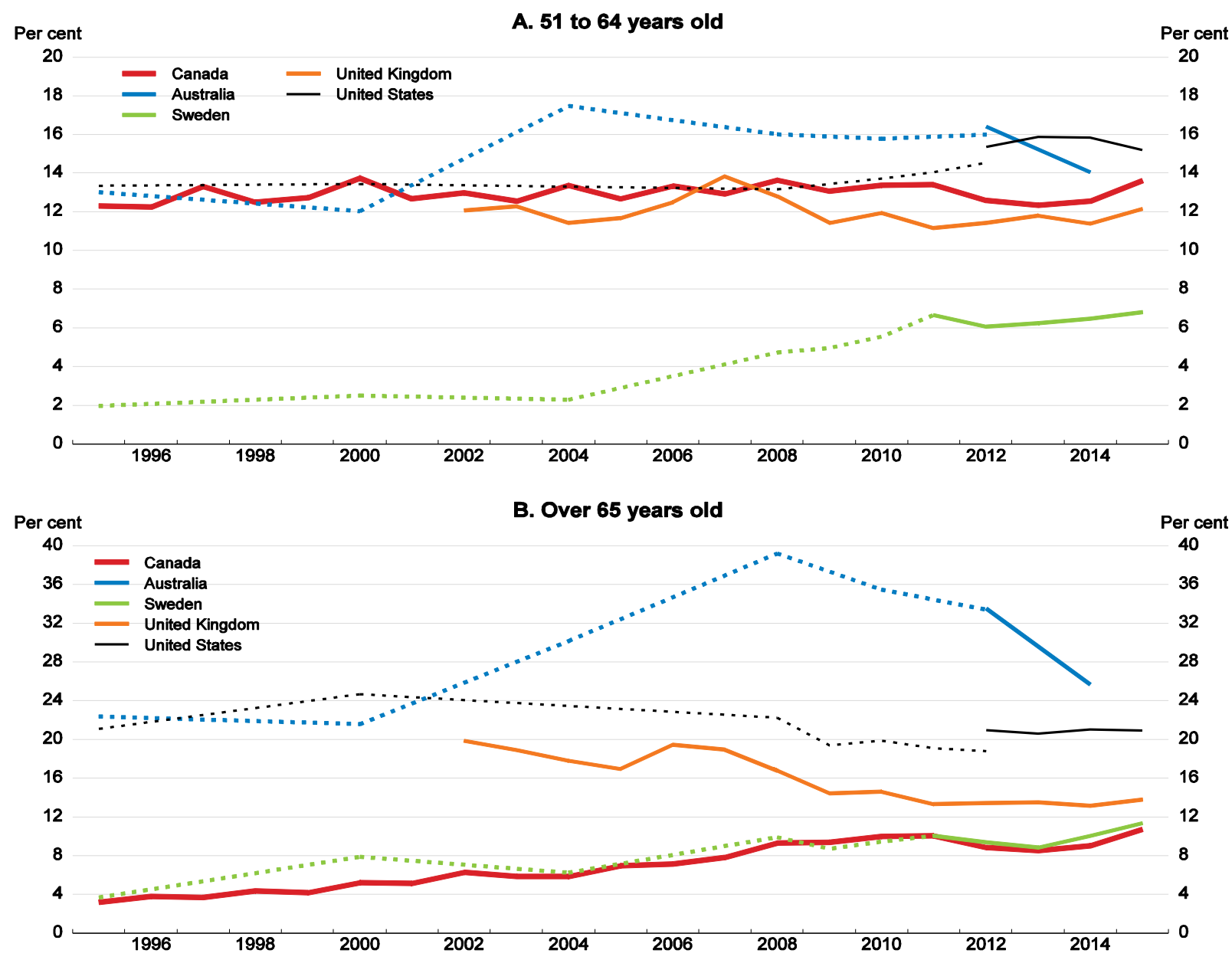

1. Dotted lines are data under the old, pre-2012 income definition.

Source: OECD (2017), Income Distribution database, http://www.oecd.org/els/soc/income-distribution-

database.htm. 


\section{There is room to increase employment of seniors}

Employment rates for older Canadians are slightly above the OECD average (Figure 25). This places Canada just behind English-speaking countries such as the United States, Australia and the United Kingdom, and around 10 percentage points behind leading OECD countries such as Iceland, New Zealand and Sweden. Cross-country analysis indicates scope to achieve small but significant increases in employment among older Canadians by increasing the normal retirement age and ALMP expenditure to match leading OECD countries (Figure 8 above).

Figure 25. Employment rates of 55 to 64 year-olds were slightly above the OECD average in 2016

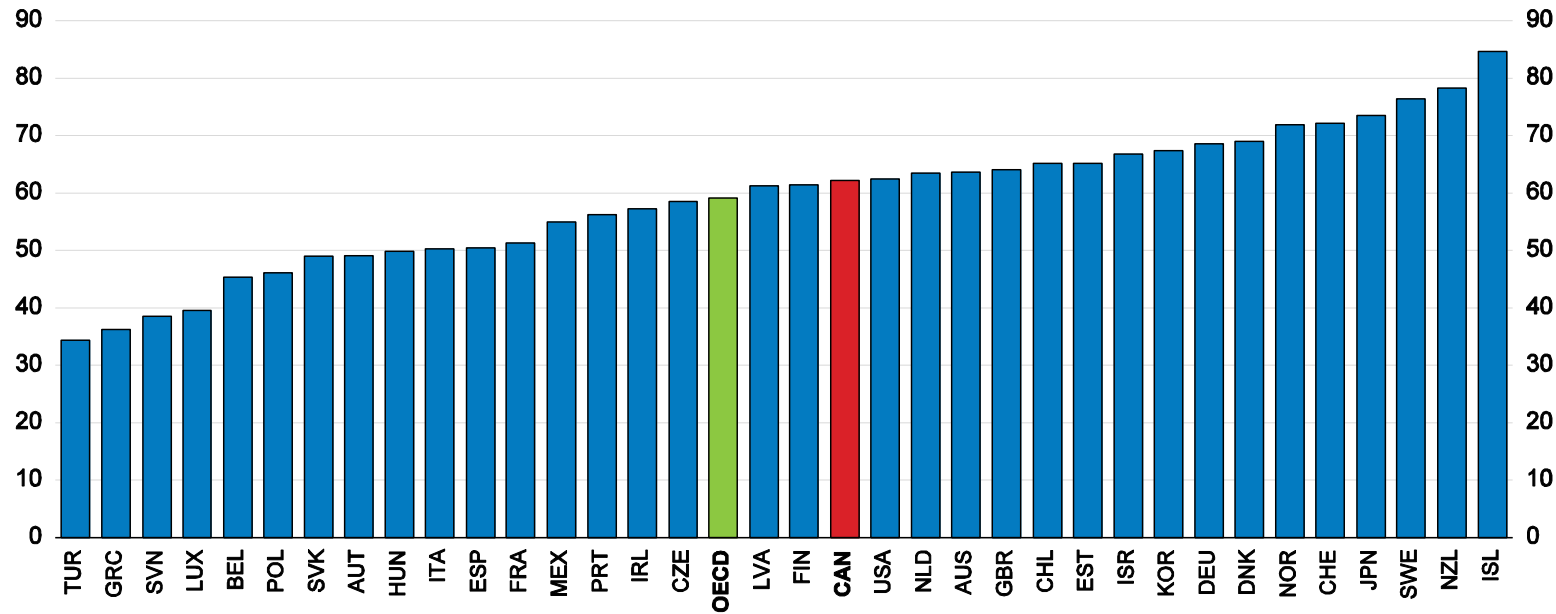

Source: OECD, Short-Term Labour Market Statistics database.

The average effective retirement age is just above the OECD average of 65 for men and just below the OECD average of 64 for women (OECD, 2017 $\left.{ }_{[130]}\right)$. Labour force participation rates for older Canadians and average retirement ages have been rising since the mid-to-late 1990s, reflecting better health, higher levels of education, pension reforms that remove penalties for delaying retirement and higher female participation. Yet, further increases in retirement ages are likely to be held back if retirements continue to cluster around 60 and 65, the ages at which CPP and other public pensions (respectively) first become payable (Figure 26). Eligibility ages have a significant effect on retirement timing decisions across OECD countries, probably reflecting their importance for liquidityconstrained individuals and/or effects on community norms (Duval, 2003 ${ }_{[131]}$ ). As in all OECD countries, participation drops considerably for those aged 65-69 and there is much unused work capacity among this age group (OECD, 2017 [90]]). 
Figure 26. The age distribution of retirement was concentrated around 60 and 65 in 2014

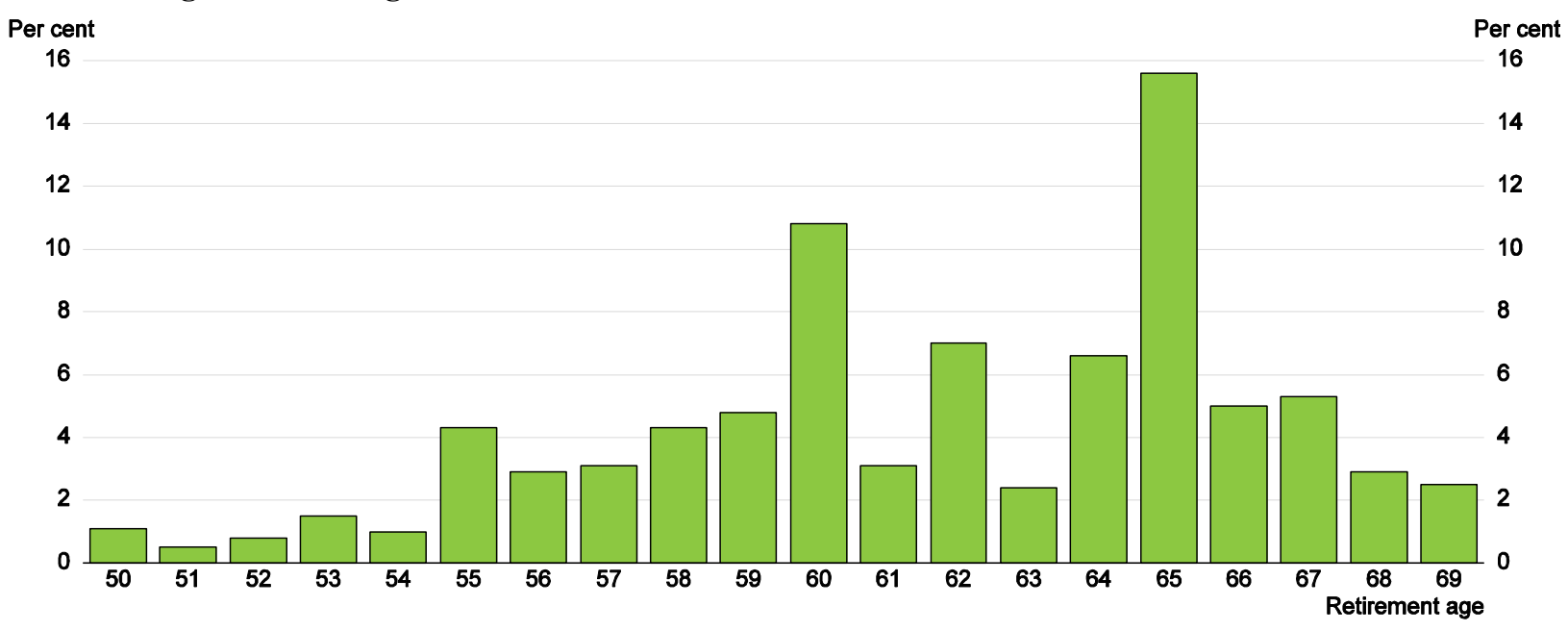

Source: Finance Canada.

\section{Reduce marginal effective tax rates for people eligible for GIS payments}

High marginal effective tax rates (METRs) for some older Canadians diminish their incentives to work. On average, changes in net pension wealth from remaining in the workforce are below the OECD average for those aged 55 to 59 and above for those aged 60 to 64 (Figure 27). Consistent with this, implicit taxes on continued work are moderate for the average Canadian worker (OECD, 2014 $\left.4_{[132]}\right)$. However, METRs exceed 50\% for many low-income earners aged 65 or over due to the steep phase-out of GIS payments. METRs are at least $75 \%$ for the range of incomes over which GIS and the GIS top-up benefit are phased out simultaneously (from CAD 2000 per year up to around CAD 8500 for singles). In British Columbia, Manitoba, Ontario and Saskatchewan, METRs and average tax rates are equal to or even exceed $100 \%$ over some low income ranges, due to the interaction of provincial and federal income supplement schemes (Laurin and Poschmann, 2014 ${ }_{[133]}$ ). These high effective tax rates reduce work incentives for current and prospective GIS recipients and are also unfair, as people who earn and/or save more can have lower net incomes than their peers.

The unemployment rate for those aged 55-64 was around 1.5 percentage points above the OECD average in 2016 (OECD, 2017 $[134]$ ). Older workers who lose their jobs are more likely to suffer extended periods of unemployment, and previous research has identified a need to expand the access of older, long-tenured, displaced workers to intensive job-search assistance, case management and training (OECD, 2015 [20]).

Effective tax rates close to or above $100 \%$ should be eliminated by reforming provincial income supplement schemes to ease phase-out provisions that overlap with that of GIS. Steps should also be taken to reduce marginal effective tax rates of at least $75 \%$ where phase-out of the GIS top-up and basic GIS overlap. However, reducing phase-out rates would increase the number of recipients on GIS, raising both fiscal costs and the number of people affected by high marginal tax rates. Many low-income seniors have weak attachment to the workforce and are thus largely unaffected by the work-disincentive effects. Among those aged 65-69, only 14\% use any part of the CAD 3500 employment income (excluding self-employment income) exemption under GIS and just $9 \%$ use all of 
it (Statistics Canada, 2017 $7_{[135]}$ ). In any case, recent analysis indicates that in practice older

Canadians respond more to average than marginal tax rates (Messacar, $2017_{[136]}$ ).

Figure 27. Incentives to remain in the workforce beyond 55 and 60 vary by age group

Changes in net pension wealth, ${ }^{1}$ as a percentage of gross annual individual earnings, 2016

\section{A. Early retirement: age 55 to 59}

2.5

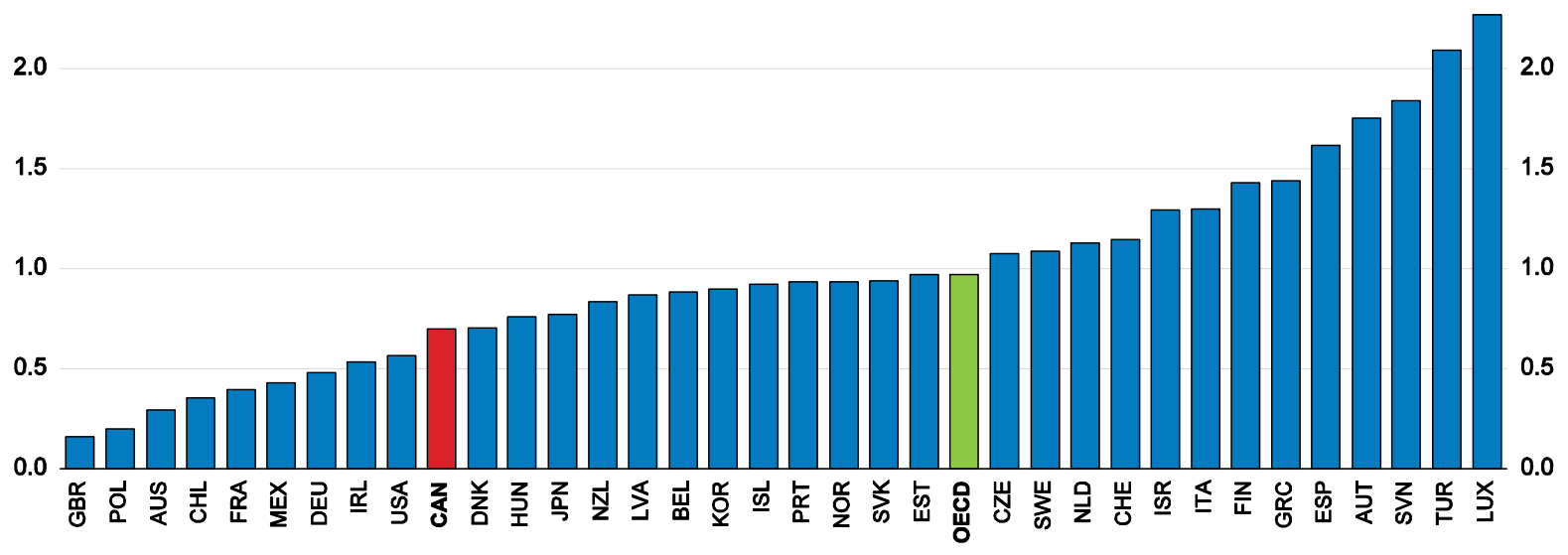

B. Old-age pension: age 60 to 64

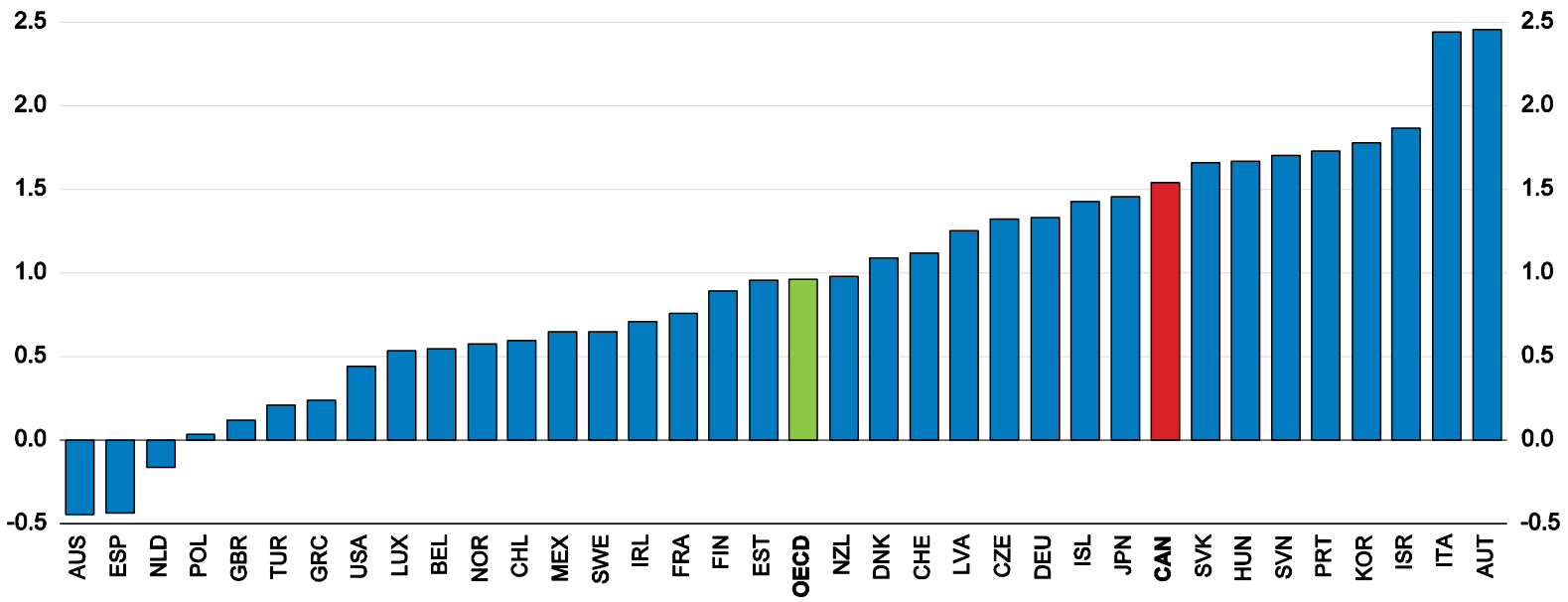

1. This concept measures the increase in the level of pension entitlements by remaining in employment for an additional year. Net pension wealth is the present value of the flow of pension benefits, taking account of the taxes and social contributions that retirees have to pay on their pensions. See OECD (2013) for more details. Source: OECD (2018), Economic Policy Reforms: Going for Growth 2018; OECD (2013), Pensions at a Glance 2013: OECD and G20 Indicators.

The retirement-timing problem associated with GIS phase-out - reduced incentives to work beyond 60 - could be addressed by increasing in-work income tax benefits specifically for older workers, beyond general increases under the Canada Workers Benefit. People aged below 65 who expect to receive GIS payments in future face reduced incentives to continue working beyond 60, as at least half of increased future CPP payments will be lost in GIS clawbacks (Laurin, Milligan and Schirle, 2012[137]). 


\section{Increase the normal retirement age in line with life expectancy}

Increasing the normal retirement age has the potential to increase employment of older Canadians, boosting growth while also delivering budgetary savings. Life expectancy at 65 increased by over $3 \frac{1}{2}$ years in the three decades to 2013 (OECD, 2017 $7_{[138]}$ ), over which time the minimum age for public first-pillar benefits and the normal age for CPP and QPP benefits were unchanged (the minimum age for CPP and QPP was reduced from 65 to 60 ). Life expectancy at 65 is projected to increase by a further $2 \frac{1}{2}$ years by 2050 (Office of the Chief Actuary, $\left.2017_{[139]}\right)$. The previous government legislated two-year increases in the ages of eligibility for public pensions over the 2023-29 period, but these changes were reversed by the current government. These age increases would have delivered fiscal savings of $0.3 \%$ of GDP in 2030 (Office of the Chief Actuary, 2016 $[140]$ ). Indexing the pension age to life expectancy, as some OECD countries have done, is a way to gradually change social norms around retirement timing while depoliticising future pensioneligibility decisions. Other retirement-age-related rules (for example, those in the tax system and provincial rules) would also need to be adjusted for later pension eligibility.

One concern is that increasing the retirement age can unduly affect low-income seniors, as these people may face challenges to working longer and often have lower-than-average life expectancy. In particular, people who do manual labour may be physically unable to work longer. While further increases in automation and mechanisation are set to make this less common, it is important to ensure that disadvantaged older workers have access to retraining and job opportunities, with adequate safety net provisions such as disability benefits as a fall-back. Health-adjusted life expectancy at 65 over 2005-07 was 3.3 years less for those in the bottom income quintile than those in the top (Statistics Canada, $\left.2018_{[141]}\right)$. This means that increasing the retirement age has a proportionately larger effect on pension wealth of low-income workers. However, this effect is quantitatively small if increases in retirement ages are matched by increases in life expectancy, in particular if indexing is incomplete (for example if the share of an average lifetime spent in retirement was to remain fixed) (OECD, 2017 $\left.{ }_{[90]}\right)$. Fortunately in Canada, unlike in the United States, recent increases in life expectancy at age 65 have been larger for those with low incomes (Statistics Canada, 2018[141]; 2018 $[142]$ ).

Inequality in life expectancy strengthens the importance of redistribution through the pension system more generally, on which front Canada performs well but could increase targeting of OAS pension payments, as these are means tested on individual incomes only and are not phased out below very high income levels (CAD 122843 in 2018). Another way to address distributional concerns would be allowing some early pension payment, on an actuarially neutral basis, as the normal retirement age increases. Of greatest importance is ensuring that there are sufficient opportunities for disadvantaged older workers through skill development and removing other barriers, as discussed below.

\section{Improve skills of older workers through lifelong learning}

Governments can assist those choosing to work longer through ensuring that the skills of the elderly are up-to-date. Strong skills are crucial for seniors to find work and will become even more so in the future, as digital technologies are likely to accelerate skills obsolescence. Literacy and numeracy skills are high among Canadians aged 55-65 and decline less across age groups than the OECD average (Figure 28). As in most OECD countries, however, older adults are generally much less proficient in computer skills: $20 \%$ of Canadian 55-65 year-olds have no computer experience or failed core ICT tests, compared with 5\% of 16-24 year-olds (OECD, 2016 $\left.6_{[118]}\right)$. Canadians' participation in adult 
education and training is above average overall but decreases with age and is much lower for those with low literacy skills or low educational attainment (OECD, 2017 $\left.{ }_{[5]} ; 2017_{[90]}\right)$. Less-skilled workers who have not received training to stabilise their cognitive capacities are more vulnerable to technological change, and research findings suggest that adult education and job-related training are most important for disadvantaged individuals with low level of education attainment and skills (OECD, 2013 $\left.{ }_{[143]} ; 2017_{[5]}\right)$.

Figure 28. The age profile of information-processing skills 2012 or $2015^{1}$

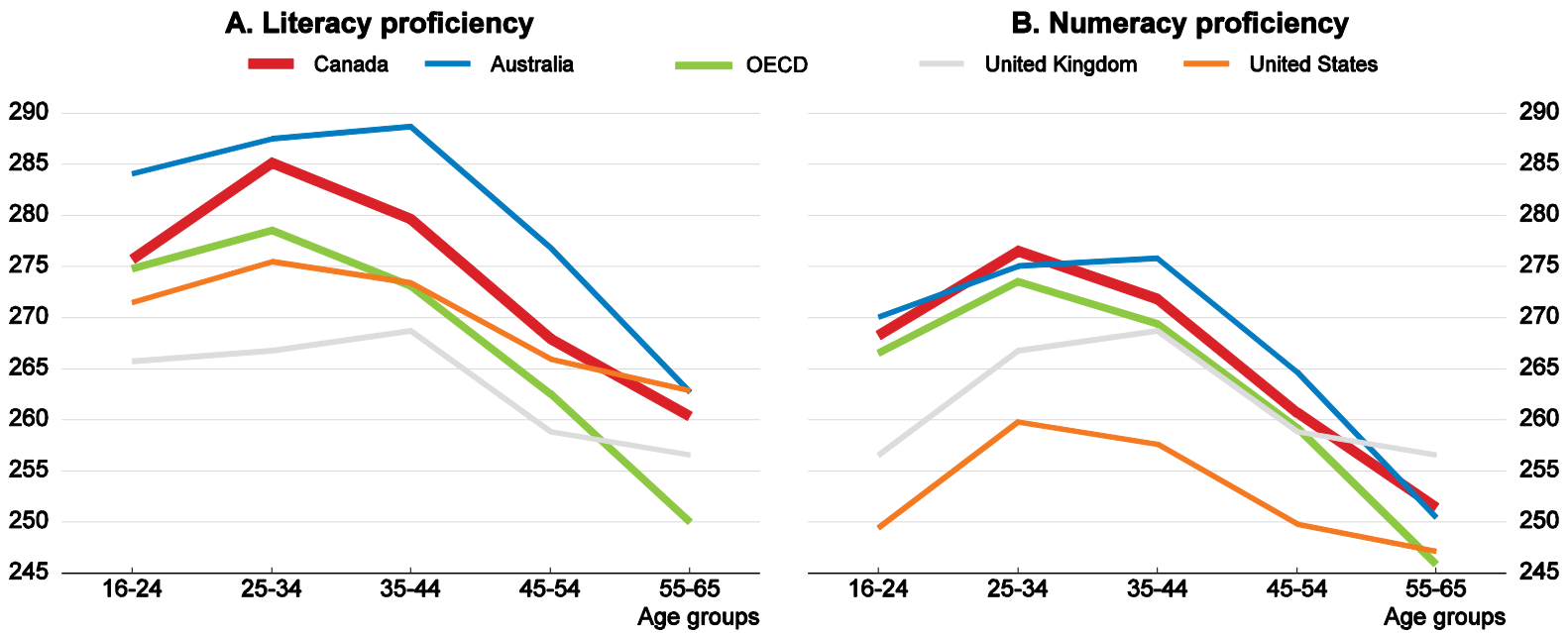

1. For the exact year of reference of the data, see footnote 2 in Figure 1.22. The UK data is composed of England and Northern Ireland.

Source: OECD (2016), Skills Matter - Further Results from the Survey of Adult Skills, Annex A; OECD Survey of Adult Skills (PIAAC) database (2012 and 2015).

Lack of access to training for those who need it most highlights the importance of prioritising equity in lifelong learning through support targeted towards the most vulnerable. Canadian governments should complement successful initiatives for co-financing of adult education and training with measures to promote innovative and flexible delivery, such as through online learning and convenient hours for those with work and/or caring responsibilities. Pilot projects commencing in 2018 under the Skills Boost plan, including targeted grants for low- and middle-income adult learners, should be evaluated once sufficient data are available and extended if found to be successful. The success of the Digital Literacy Exchange program, which supports teaching of fundamental digital literacy skills to Canadians, should also be monitored. New Labour Market Transfer Agreements (as discussed above) give provinces greater flexibility to respond to specific training needs in their jurisdiction, but it is too early to assess the effects on opportunities for lifelong learning for the most vulnerable.

\section{Remove other barriers to employment of older workers}

A lack of job flexibility precludes many older workers from choosing their working hours, resulting in earlier retirement. In Canada over one quarter of retirees state that they might have changed their decision to retire if they had been able to reduce their work schedule (Morissette, Schellenberg and Silver, $\left.2004_{[144]}\right)$. Adapting working arrangements to the capacities of older workers can allow them to maintain their productivity equal to that of prime-age workers (Sonnet et al., 2014 $4_{[145]}$ ). To increase workforce participation, 
governments should promote phased retirement and workweek flexibility for older Canadians. One way to do this is through government cooperation with employer groups to educate businesses on the benefits of offering flexible work arrangements and the small costs of their set-up and management (Steeve et al., 2017 $[128]$ ).

Anti-discrimination legislation and information provision regarding the potential benefits from experienced employees can be useful to support demand for older workers. However, special employment protection rules for older workers should be avoided, as these can reduce the incentives for firms to hire and retain older workers. Disability is often a barrier to continued work, as the incidence of disability increases markedly with age. Prevention policy regarding smoking, drinking and obesity has the potential to reduce health inequalities by delivering the greatest benefits to vulnerable population groups, while also improving their labour market outcomes (OECD, 2017 $\left.{ }_{[90]}\right)$.

\section{Curb old-age poverty through further real increases in public pensions}

Currently, a decline in living standards after retirement is largely a middle- and upperincome earner problem, concentrated among those not in a workplace pension plan. Gross replacement rates for lower income earners are high, in many cases exceeding 100\% compared with a common benchmark for retirement income adequacy of $70 \%$ (Baldwin and Shillington, 2017 [146]; Ostrovsky and Schellenberg, 2010 $0_{[147]}$ ). Canada has achieved high replacement rates for low-income earners while spending only $4 \frac{1}{2}$ per cent of GDP on pensions, well below the OECD average of $8 \%$ (Figure 29). This has been done through strict income testing of access to the GIS component of first-pillar pensions, redistribution through the first and second pillars and a reliance on occupational pension plans and taxfavoured individual savings (the third pillar) to provide adequate retirement incomes for higher-income earners. All these factors contribute to a fairly high progressivity of the oldage pension system in Canada (OECD, 2017 ${ }_{[90]}$ ), which helps limit inequality in pension incomes.

Figure 29. Public expenditure on pensions is low

Old age and survivors pensions as a percentage of GDP, 2015 or latest available year

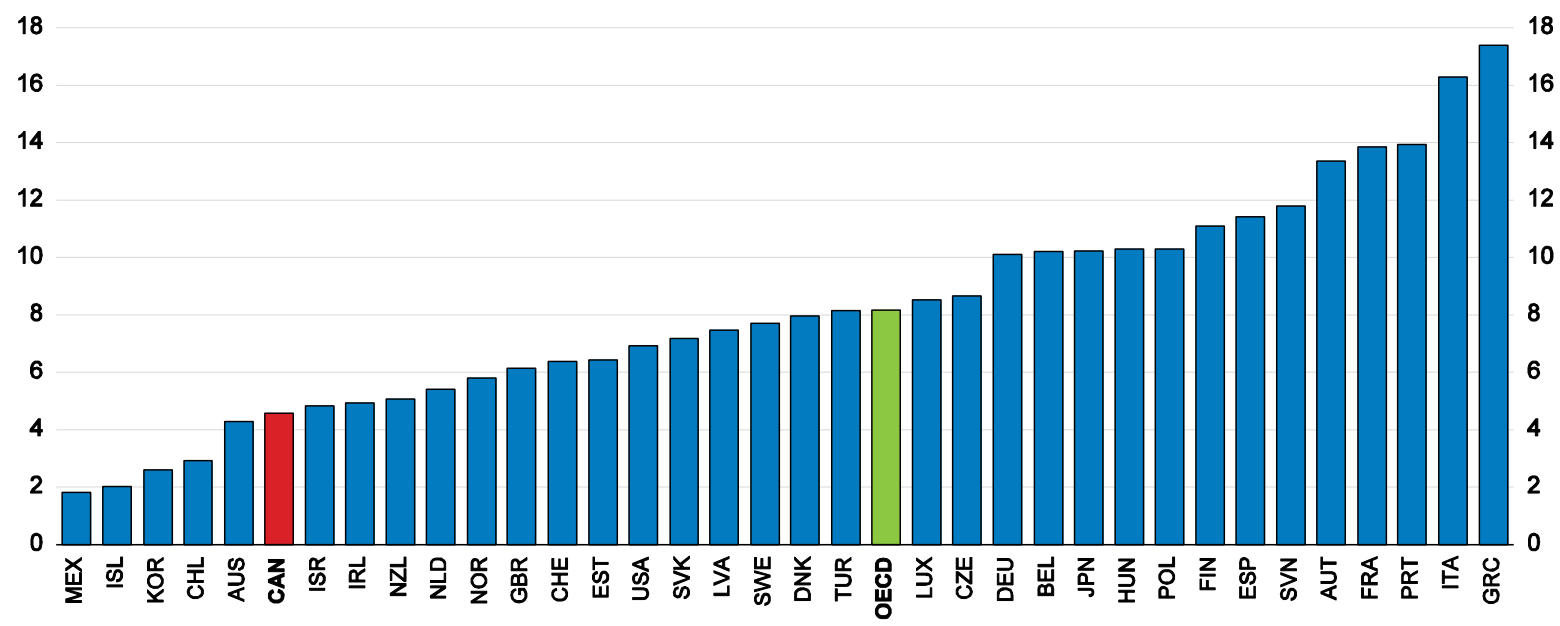

Source: OECD, Social Expenditure database.

In the future, however, CPI indexing of first-pillar OAS benefits is likely to create retirement income problems for some low earners given expected real wage growth. Based 
on Canadian pension legislation and an internationally standardised set of assumptions for earnings and price growth, people aged 20 in 2016 who earn half the average wage throughout their career are expected to receive a gross replacement rate of just $54 \%$ from mandatory public and private pension schemes when they retire, compared with the OECD average of $65 \%\left(\mathrm{OECD}, 2017_{[130]}\right)$. Changing to full wage indexation would put Canada above the OECD average, as this is estimated to add 28 percentage points to their replacement rates $\left(\mathrm{OECD}, 2015_{[148]}\right)$. The biggest effect of declining replacement rates from public pension payments due to CPI indexing will be felt by low-income earners, with up to $20 \%$ of low-income earners in 2015 projected to experience a decline in living standards when they retire (Moore, Robson and Laurin, 2010 $\left.{ }_{[149]}\right)$. Indexing first-pillar pensions to the CPI also does not allow for the possibility that seniors might face faster increases in the cost of living due to different consumption patterns, such as a lower share of spending on electronics and a higher share on healthcare. However, earlier Statistics Canada research shows that in practice seniors-only households experienced a similar rate of inflation to other households (Chiru, 2005 $[150]$ ).

The federal government needs to ensure that it continues to share the fruits of economic growth with low-income seniors through real increases in pension payments. This could be achieved through more generous indexing of OAS and GIS payments, where there are a number of different implementation options (Table 4). Alternatively, real increases in public pensions could continue to be delivered through ad hoc adjustments.

Table 4. Options to introduce more generous indexation of public pensions

\begin{tabular}{|c|c|c|c|c|}
\hline & Benefits & Drawbacks & $\begin{array}{l}\text { Examples in other } \\
\text { OECD countries }\end{array}$ & Estimated cost \\
\hline $\begin{array}{l}\text { Full indexation } \\
\text { to wages }\end{array}$ & $\begin{array}{l}\text { Maintain relativities of } \\
\text { public pensions to } \\
\text { working incomes }\end{array}$ & $\begin{array}{l}\text { Substantial fiscal costs. } \\
\text { Compression of pension } \\
\text { benefits from inconsistent } \\
\text { indexation - CPP } \\
\text { payments are indexed to } \\
\text { prices - reducing } \\
\text { incentives to work longer }\end{array}$ & $\begin{array}{l}\text { Denmark, } \\
\text { Germany and } \\
\text { Ireland; also } \\
\text { United Kingdom if } \\
\text { wage growth } \\
\text { exceeds price } \\
\text { growth }\end{array}$ & $\begin{array}{l}0.3 \% \text { of GDP in } 2030 \\
1.5 \% \text { of GDP in } 2060\end{array}$ \\
\hline $\begin{array}{l}\text { Indexation to a } \\
\text { weighted } \\
\text { average of } \\
\text { consumer } \\
\text { prices }(\mathrm{CPI}) \\
\text { and wage } \\
\text { growth }\end{array}$ & $\begin{array}{l}\text { Less costly than full } \\
\text { indexation to wages }\end{array}$ & $\begin{array}{l}\text { Replacement rates for } \\
\text { those relying on public } \\
\text { pensions still decline over } \\
\text { time }\end{array}$ & $\begin{array}{l}\text { Czech Republic, } \\
\text { Estonia and } \\
\text { Switzerland }\end{array}$ & $\begin{array}{l}\text { Indexing } 40 \% \text { to } \mathrm{CPI} \\
\text { and } 60 \% \text { to wages: } \\
0.9 \% \text { of GDP in } 2060\end{array}$ \\
\hline $\begin{array}{l}\text { Indexation to } \\
\text { wages until } \\
\text { retirement then } \\
\mathrm{CPI} \text { after } \\
\text { retirement. }\end{array}$ & $\begin{array}{l}\text { Prevent a fall in } \\
\text { replacement rates over } \\
\text { time, while maintaining } \\
\text { living standards for } \\
\text { those in retirement } \\
\text { Consistency of } \\
\text { indexation with CPP } \\
\text { and (at the time of } \\
\text { retirement) with } \\
\text { unemployment benefits }\end{array}$ & $\begin{array}{l}\text { Additional complexity and } \\
\text { perceived unfairness of } \\
\text { different payments for } \\
\text { people of different ages } \\
\text { Substantial long-term } \\
\text { fiscal costs }\end{array}$ & $\begin{array}{l}\text { Basic contributory } \\
\text { pensions in Japan }\end{array}$ & $\begin{array}{l}\text { Similar cost as } \\
\text { indexing } 40 \% \text { to } \mathrm{CPI} \\
\text { and } 60 \% \text { to wages } \\
\text { over about } 30 \text { years }\end{array}$ \\
\hline
\end{tabular}

Source: OECD (2017), Pensions at a Glance 2017: OECD and G20 Indicators; OECD (2015), Pensions at a Glance 2015: OECD and G20 indicators; Office of the Chief Actuary (2017), 14th Actuarial Report on the Old Age Security Program as at 31 December 2015.

Discretionary adjustments give governments the capacity to better target emerging areas of need (such as increased GIS payments for singles in the 2016 budget) but are also subject 
to political processes and less clearly linked to economic and wage growth. Canada has no long-term budgetary need to reduce the value of public pension payments, which currently account for a relatively low share of GDP, and replacement rates are not especially high.

\section{Make long-term care more responsive to user needs}

Long-term care is expensive and can trigger financial problems for older Canadians. People on low incomes are the most likely to become disabled and the least likely to be able to afford professional care, leaving them at risk of unmet needs. In Canada, as in several other major OECD countries, the cost of care for someone with heavy needs recently topped $60 \%$ of disposable income even for those among the eighth (i.e. third-highest) income decile (Colombo et al., 2011 $1_{[151]}$ ). The cost of institutional care is particularly high in Canada, with both of the Canadian provinces analysed by Muir (2017 [152]) (Ontario and Nova Scotia) falling in the top half of jurisdictions studied.

Canadian governments spent $1.1 \%$ of GDP on long-term care in 2014, just below the OECD average of $1.4 \%\left(\mathrm{OECD}, 2017_{[153]}\right)$. Around $80 \%$ of long-term care costs are publicly funded. There is also considerable in-home care provision by family and friends: the size of the family care "workforce" is estimated to be more than ten times the size of the formalcare workforce in Canada, as in a few other OECD countries (Colombo et al., 2011 $1_{[151]}$ ). The value of informal care in Canada was estimated at CAD 27 billion (1.6\% of GDP) in 2010, exceeding the estimated annual fiscal cost of institutional elderly care of CAD 24 billion (Busby and Blomqvist, 2016 ${ }_{[154]}$; Blomqvist and Busby, 2014 ${ }_{[155]}$ ).

Despite substantial government funding, unmet needs remain. A few years ago just over $10 \%$ of people with long-term home-care needs did not receive any services, and a further $10 \%$ of people who received home care required more care than they are getting (Turcotte, $\left.2014_{[156]}\right)$. People in need of non-urgent care are increasingly on waiting lists or deemed ineligible for publicly funded services to which they once had access (Donner et al., $\left.2015_{[157]}\right)$. In a recent survey of people who needed help with daily living activities, 19\% of people in Canada did not receive the assistance that they needed because of costs, compared to $2-10 \%$ of respondents in most countries outside North America (Osborn et al., $\left.2017_{[158]}\right)$. Fifteen per cent of acute-care hospital beds are estimated to be occupied by people who would be better off or would prefer to be at home or in community-based setting (Sutherland and Crump, 2011 ${ }_{[159]}$; Government of Canada, 2017 ${ }_{[160]}$ ).

A shortage of formal care puts heavy strain on carers, the majority of whom are women. Across OECD countries, carers face an increased risk of mental health problems and may find it difficult to remain in work (Colombo et al., 2011 [151]). Carers are supported through federal and provincial tax credits, Employment Insurance Family Caregiver benefits, carers' allowances at the provincial level and respite care.

Demand for long-term care is set to increase rapidly as the population over 65 is projected to more than double between 2011 and 2036 (Morency, Malenfant and MacIsaac, $\left.2017_{[161]}\right)$. Public costs of long-term care are predicted to increase by more than $50 \%$ as a share of GDP by 2040, holding the degree of public subsidisation fixed (Blomqvist and Busby, $\left.2014_{[155]}\right)$. There is a risk that informal-care provision will not be able to expand in proportion to demand, as the elderly population share rises and as women have stronger attachment to the labour force and thus greater opportunity costs of caring. The 2017 federal budget dedicated an additional CAD 6 billion over 10 years for home care, including funding to provinces to improve access to home-, community- and palliative-care services as well as more support for informal caregivers. 
Governments should act to provide greater consumer choice regarding the basket of publicly funded services received, as recommended by Ontario's Expert Group on Home and Continuing Care (Donner et al., 2015 [157] $)$ and Busby and Blomqvist $\left(2016_{[154]}\right)$. In most cases, people in need of care and their families will be best placed to decide what care is needed and whether to remain at home. Canadians in need of care and their families have a desire to be actively involved in the development and implementation of their care plan, with flexibility in tailoring the plan to their family's unique and evolving situation (Donner et al., 2015[157]). Competition among providers where consumers are free to choose the personal- and nursing-care services they require can lead to a more dynamic system, with enhanced incentives for efficiency, innovation and quality. This needs to be supported by information provision as well as adequate regulatory oversight of safety and quality standards to protect vulnerable consumers and ensure that information asymmetries between providers and consumers are not exploited. There have been some success stories in moves toward more self-directed care in Canada, such as tele-home-care initiatives that have led to a reduction in hospital admissions while improving clients' self-management ability (Colombo et al., 2011 $1_{[151]}$ ). Australia's National Disability Insurance Scheme is an example where greater user choice supported the emergence of a market with an expanded range of personal care services and contributed to greater well-being for participants (Mavromaras et al., 2018 [162]).

Additional funding is needed to confront waiting lists and ensure that future demand growth can be met. Private long-term-care insurance is unlikely to overcome funding gaps: even in OECD countries with the broadest coverage, less than $10 \%$ of the population aged 40 and above hold such insurance, and in most OECD countries less than $2 \%$ of total longterm-care expenditure is financed through private long-term-care insurance (Colombo et al., $\left.2011_{[151]}\right)$. There are a number of reasons for this, including low product awareness, myopic decision-making and adverse selection.

A possible alternative to the current system of funding out of general revenue (pooling risks through the social security system) is a social insurance approach with dedicated channels for financing long-term care, as in Germany, Japan, Korea, Luxembourg and the Netherlands (Colombo et al., 2011 $1_{[151]}$ ). This can ensure a reliable and predictable source of revenue while creating a sense of entitlement for people, raising their willingness to pay, and can also improve intergenerational equity to the extent that funding available for each generation matches their contributions. However, it is too late for such an approach to fund a substantial part of the long-term care costs of the baby-boom generation. A compulsory insurance model would also raise substantial design and transitional issues, such as who would administer the scheme, and how the rate of contributions would vary with income and age and adjust to changes in expected future costs, as well as how to smooth the transition from pay-as-you-go to pre-funding.

Another potential source of financing to expand the provision of long-term care is greater reliance on user charges, in particular for non-healthcare services. User charges are calibrated to ability to pay using means tests, but currently only two provinces - Québec, and Newfoundland and Labrador - take into account assets in assessing ability to pay. In practice, income is correlated with assets, but the incidence of income-poor/asset-rich older Canadians is likely to have increased with rapid appreciation of house prices. Average wealth among Canadians aged 70 to 74 increased more than four-fold in real terms between 1984 and 2012, exceeding real average income growth of just over 50\% (Sarlo, 2017 $[163]$ ). Including assets in the means test can broaden the base of users contributing to the cost of care and better reflects the distribution of ability to pay and economic welfare among individuals, but it can also make the system more cumbersome to administer. Public-sector 
mechanisms used in other OECD countries to allow users to mobilise cash from home ownership include bonds/equity release and similar interest-free loan schemes (as in Australia) and measures to defer payment of nursing-home costs (Ireland and some local councils in the United Kingdom).

User charges for low- and moderate-needs homecare could be increased without exceeding affordability thresholds. Most Canadian provinces provide nursing- and personal-care coverage without charge in home-care settings, and as a consequence care recipients earning median incomes pay a smaller share of their disposable incomes in Ontario and Nova Scotia than in many other OECD countries (Muir, 2017 $[152]$ ). Any increase in copayments for home-based care needs to be calibrated with co-payments for institutional care to avoid creating incentives to move out of the home for low- or moderate-level care, which would raise overall budgetary costs.

Recommendations to increase inclusiveness for women, youth and seniors

(Key recommendations are in bolded text)

- Review active labour market programmes with a view to further increase funding for effective measures through expanding eligibility and/or providing greater access to more intensive re-employment counselling and retraining.

- Introduce independent expert commissions to periodically update provincial minimum wages, including the scope for regional variation and lower minimum wages for youth.

\section{Inclusiveness for women}

- Further increase federal and provincial funding of childcare with a goal of making access to affordable high-quality childcare available to all children aged three and under.

- Extend kindergarten so that all four year-old children have access to affordable pre-school education.

- Improve the quality of early childhood education through expansion of regulatory oversight, development of professional capacity and collection and use of outcomes data.

- Support take-up of new parental leave by fathers through information provision and, if necessary, increasing payment rates.

- Make in-work tax benefits more generous for low-income single parents, as planned.

- Take further steps to address financial, mentorship and support-programme barriers to female entrepreneurship through a comprehensive national strategy for women's enterprises, underpinned by more gender-disaggregated data.

Inclusiveness for youth

- Consolidate the existing range of career guidance and education information into a single national portal to provide a comprehensive onestop shop. 
- Continue to promote basic skills development through school-based education and adult- learning programmes, particularly for students from disadvantaged backgrounds.

- Improve the accessibility and reputation of apprenticeship and vocational education systems through increasing funding certainty for pre-apprenticeship training and encouraging further development of pathways to advanced diplomas and degrees.

Inclusiveness for seniors

- Index the eligibility age for public pensions to life expectancy, supported by encouraging flexibility in working hours and skill development.

- Reduce clawback rates for GIS top-up benefits, and reform provincial income supplement schemes for seniors to reduce marginal effective tax rates to well below $100 \%$.

- Further increase in-work tax benefits for low-income earners aged over 60 to increase incentives to remain in the workforce.

- Manage growing demand for long-term care by improving the targeting of public payments, wider application of user charging and further encouraging home-care services. 


\section{References}

Adema, W., C. Clarke and V. Frey (2015), "Paid Parental Leave: Lessons from OECD Countries and Selected U.S. States", OECD Social, Employment and Migration Working Papers, No. 172, OECD Publishing, Paris, http://dx.doi.org/10.1787/5jrqgvqqb4vb-en.

Advisory Council on Economic Growth (2017), Tapping economic potential through broader workforce participation.

Akbari, E. and K. McCuaig (2018), Early Chilhood Education Report 2017, Atkinson Centre for Society and Child Development, Ottawa, http://ecereport.ca/en/.

Albrecht, J., P. Thoursie and S. Vroman (2015), "Parental Leave and the Glass Ceiling in Sweden", http://dx.doi.org/10.1108/S0147-912120140000041010.

Alexander, C. et al. (2017), Ready for Life: A Socio-Economic Analysis of Early Childhood Education and Care, The Conference Board of Canada, Ottawa, http://www.conferenceboard.ca/e-library/abstract.aspx?did=9231.

Almqvist, A. and A. Duvander (2014), "Changes in gender equality? Swedish fathers' parental leave, division of childcare and housework", Journal of Family Studies, Vol. 20/201, pp. 1927, http://dx.doi.org/10.5172/jfs.2014.20.1.19.

Álvarez-Galván, J. et al. (2015), A skills beyond school commentary on Canada, OECD, Paris, https://www.oecd.org/education/a-skills-beyond-school-commentary-on-canada.pdf.

Anderson, L., M. Ballantyne and M. Friendly (2016), Child Care for All of Us: Universal Child Care for Canadians by 2020, Canadian Centre for Policy Alternatives, Ottawa, https://www.policyalternatives.ca/sites/default/files/uploads/publications/National\%20Office/ 2016/12/Child_Care_AFB2017_technical_paper.pdf.

Australian Government (2017), Closing the Gap, Department of the Prime Minister and Cabinet, Canberra, https://closingthegap.pmc.gov.au/executive-summary.

Baker, M. and N. Fortin (2004), "Comparable worth in a decentralized labour market: the case of Ontario", Canadian Journal of Economics/Revue Canadienne d'Economique, Vol. 37/4, pp. 850-878, http://dx.doi.org/10.1111/j.0008-4085.2004.00251.x.

Baker, M., J. Gruber and K. Milligan (2015), "Non-Cognitive Deficits and Young Adult Outcomes: The Long-Run Impacts of a Universal Child Care Program", NBER, http://www.nber.org/papers/w21571.

Baker, M., J. Gruber and K. Milligan (2008), "Universal Child Care, Maternal Labor Supply, and Family Well-Being", Journal of Political Economy, Vol. 116/4, pp. 709-745, http://dx.doi.org/10.1086/591908.

Baldwin, B. and R. Shillington (2017), Unfinished Business: Pension Reform in Canada, IRPP, Montreal, http://irpp.org/fr/research-studies/study-no64/. 
Bassanini, A. and R. Duval (2006), "Employment Patterns in OECD Countries: Reassessing the Role of Policies and Institutions", OECD Social, Employment and Migration Working Papers.

Bear, S., N. Rahman and C. Post (2010), "The Impact of Board Diversity and Gender Composition on Corporate Social Responsibility and Firm Reputation", Journal of Business Ethics, Vol. 97, pp. 207-221, http://dx.doi.org/10.1007/s10551-010-0505-2.

Beaudry, P. and D. Green (2000), "Cohort patterns in Canadian earnings: assessing the role of skill premia in inequality trends", Canadian Journal of Economics/Revue Canadienne d'Economique, Vol. 33/4, pp. 907-936, http://dx.doi.org/10.1111/0008-4085.00047.

Bergemann, A. and G. Van den Berg (2008), “Active Labor Market Policy Effects for Women in [102] Europe - A Survey", Annales d'Économie et de Statistique 91/92, p. 385, http://dx.doi.org/10.2307/27917252.

BIAC (2018), Preparing All our Minds for Work: Girls, Women, and Learning Over a Lifetime, Business at OECD, http://biac.org/wp-content/uploads/2018/03/Final-Final-Business-atOECD-Education-Workshop-Report1.pdf.

Blomqvist, A. and C. Busby (2014), Paying for the Boomers: Long-Term Care and Intergenerational Equity, CD Howe Institute, Toronto, http://dx.doi.org/10.2139/ssrn.2498537.

Boll, C., J. Leppin and N. Reich (2014), "Paternal childcare and parental leave policies: evidence from industrialized countries", Review of Economics of the Household, Vol. 12/1, pp. 129158, http://dx.doi.org/10.1007/s11150-013-9211-z.

Brouillette, D. et al. (2017), The Impacts of Minimum Wage Increases on the Canadian Economy, Bank of Canada, Ottawa, https://www.bankofcanada.ca/2017/12/staff-analyticalnote-2017-26/.

Bünning, M. (2015), “What Happens after the 'Daddy Months'? Fathers' Involvement in Paid Work, Childcare, and Housework after Taking Parental Leave in Germany", European Sociological Review, Vol. 31/6, pp. 738-748, http://dx.doi.org/10.1093/esr/jcv072.

Busby, C. and A. Blomqvist (2016), Shifting Towards Autonomy: A Continuing Care Model for Canada, CD Howe Institute, Toronto, http://dx.doi.org/10.2139/ssrn.2718542.

Caldera-Sanchez, A. et al. (2016), Strengthening economic resilience: insights from the post1970s record of severe recessions and financial crises, OECD Economic Policy Paper, Paris, https://www.oecd.org/eco/growth/Strengthening-economic-resilience-insights-from-the-post1970-record-of-severe-recessions-and-financial-crises-policy-paper-december-2016.pdf.

Caledon Institute (2014), What you need to know about the Canada job fund, Caledon Institute of Social Policy, Toronto, https://maytree.com/wp-content/uploads/1058ENG.pdf. 
Canada-United States Council for Advancement of Women Entrepreneurs and Business Leaders

[104] (2018), Attracting Women Entrepreneurs, Encouraging Women to Start Businesses, https://advancingwomeninbusiness.com/wp-content/uploads/2018/03/Attracting-WomenEntrepreneurs-Encouraging-Women-to-Start-Businesses Report.pdf.

Canada-United States Council for Advancement of Women Entrepreneurs and Business Leaders (2018), Increasing the Number of Women in Science, Technology, Engineering and Math (STEM), https://advancingwomeninbusiness.com/wpcontent/uploads/2018/03/IncreasingtheNumberofWomeninSTEM_Report.pdf.

Canadian Medical Association (2017), Canadian Physician Statistics, https://www.cma.ca/En/Pages/canadian-physician-statistics.aspx.

Card, D. and A. Payne (2017), High School Choices and the Gender Gap in STEM, National Bureau of Economic Research, Cambridge, MA, http://dx.doi.org/10.3386/w23769.

Causa, O. and M. Hermansen (2017), "Income redistribution through taxes and transfers across OECD countries", OECD Economics Department Working Papers, No. 1453, OECD Publishing, Paris, http://dx.doi.org/10.1787/bc7569c6-en.

Chief Public Health Officer (2016), Health Status of Canadians 2016, http://healthycanadians.gc.ca/publications/department-ministere/state-public-health-status2016-etat-sante-publique-statut/alt/pdf-eng.pdf.

Chiru, R. (2005), Is Inflation Higher for Seniors?, Statistics Canada, Ottawa.

Clarke, J. (2016), Health at a glance: Difficulty accessing health care services in Canada, http://www.statcan.gc.ca/pub/82-624-x/2016001/article/14683-eng.htm.

CMHC (2017), Rental Market Survey.

Colombo, F. et al. (2011), Help Wanted?: Providing and Paying for Long-Term Care, OECD Health Policy Studies, OECD Publishing, Paris, http://dx.doi.org/10.1787/9789264097759en.

Conference Board of Canada (2017), Ready for Life: A Socio-Economic Analysis of Early Childhood Education and Care, http://www.conferenceboard.ca/elibrary/abstract.aspx?did=9231.

Corak, M. (2016), “'Inequality is the root of social evil,' or Maybe Not? Two Stories about Inequality and Public Policy", Canadian Public Policy, Vol. 42/4, pp. 367-414, http://dx.doi.org/10.3138/cpp.2016-056.

Cukrowska-Torzewska, E. (2016), "Comparative analysis of the motherhood gap in employment and wages: the role of family policies and their interaction", Budapest Working Papers on the Labour Market, Hungarian Academy of Sciences, Budapest.

Dahl, G., K. Løken and M. Mogstad (2014), "Peer Effects in Program Participation”, American Economic Review, Vol. 104/7, pp. 2049-2074, http://dx.doi.org/10.1257/aer.104.7.2049. 
Department of Finance Canada (2016), Report on Federal Tax Expenditures - Concepts, Estimates and Evaluations 2016.

Donner, G. et al. (2015), Bringing Care Home: Report of the Expert Group on Home \&amp; Community Care, http://health.gov.on.ca/en/public/programs/lhin/docs/hcc_report.pdf.

Drummond, D. et al. (2017), The Contribution of Aboriginal People to Future Labour Force Growth in Canada, Centre for the Study of Living Standards, http://www.csls.ca/reports/csls2017-07.pdf.

Duval, R. (2003), Retirement behavious in OECD countries: impact of old-age pension schemes and other social transfer programmes, OECD, Pari, https://www.oecd.org/eco/growth/34561950.pdf.

Ekberg, J., R. Eriksson and G. Friebel (2013), "Parental leave - A policy evaluation of the Swedish "Daddy-Month" reform", Journal of Public Economics, Vol. 97, pp. 131-143, http://dx.doi.org/10.1016/J.JPUBECO.2012.09.001.

Flores, M. and C. Geppert (2018), Lifetime Earnings by Cohort, Gender and Education, OECD Social, Employment and Migration Working Papers, forthcoming.

Fortin, N., B. Bell and M. Böhm (2017), “Top Earnings Inequality and the Gender Pay Gap: Canada, Sweden and the United Kingdom", Discussion Paper Series, IZA Institute of Labour Economics, http://ftp.iza.org/dp10829.pdf.

Fortin, P. (2018), "Quebec's Childcare Program at 20", Inroads: The Canadian Journal of Opinion 42, http://inroadsjournal.ca/quebecs-childcare-program-20-2/.

Fortin, P. (2016), What can we learn from Quebec's 20-year-old child care reform?, Gideon Rosenbluth Memorial Lecture, Vancouver.

Fortin, P., L. Godbout and S. St-Cerny (2013), Impact of Quebec's Universal Low-Fee Childcare Program on Female Labour Force Particiaption, Domestic Income, and Government Budgets, https://www.oise.utoronto.ca/atkinson/UserFiles/File/News/Fortin-GodboutSt_Cerny_eng.pdf.

Fox, D. and M. Moyser (2018), The Economic Well-Being of Women in Canada Women in Canada: A Gender-based Statistical Report, Statistics Canada, Ottawa, http://www.statcan.gc.ca/pub/89-503-x/2015001/article/54930-eng.pdf.

Frenette, M. (2017), Postsecondary Enrolment by Parental Income: Recent National and [109] Provincial Trends, Statistics Canada, Ottawa, http://www.statcan.gc.ca/pub/11-626-x/11-626x2017070-eng.htm.

Frenette, M. (2007), Why Are Youth from Lower-income Families Less Likely to Attend University? Evidence from Academic Abilities, Parental Influences, and Financial Constraints, Statistics Canada, https://www.statcan.gc.ca/pub/11f0019m/11f0019m2007295eng.htm. 
Gambaro, L., K. Stewart and J. Waldfogel (2014), An equal start? : providing quality early education and care for disadvantaged children, Policy Press.

Ginther, D. and J. Rosenbloom (2015), Why Do Women Leave IT? Examining the Factors Associated with the Gender Gap in Information Technology Occupations, APPAM, Miami, https://appam.confex.com/appam/2015/webprogram/Paper13608.html.

Government of Canada (2017), Building a strong middle class: Budget 2017.

Green, D. (2015), The Case for Increasing the Minimum Wage: What Does the Academic Literature Tell Us?, Canadian Centre for Policy Alternatives, Vancouver, https://www.policyalternatives.ca/sites/default/files/uploads/publications/BC\%20Office/2015/ 04/CCPA-BC-Case-for-Incr-Minimum-Wage 0.pdf.

Highly Skilled Workforce Expert Panel (2016), Building the Workforce of Tomorrow: A Shared Responsibility, Report Submitted to the Premier of Ontario, Toronto.

Huerta, M. et al. (2013), “Fathers' Leave, Fathers' Involvement and Child Development: Are They Related? Evidence from Four OECD Countries", OECD Social, Employment and Migration Working Papers, No. 140, OECD Publishing, Paris, http://dx.doi.org/10.1787/5k4dlw9w6czq-en.

Hunt, J. (2016), “Why do Women Leave Science and Engineering?”, ILR Review, Vol. 69/1, pp. 199-226, http://dx.doi.org/10.1177/0019793915594597.

IMF (2017), IMF Fiscal Monitor: Tackling Inequality, https://www.imf.org/en/Publications/FM/Issues/2017/10/05/fiscal-monitor-october-2017.

Immervoll, H. and M. Pearson (2009), “A Good Time for Making Work Pay? Taking Stock of In-Work Benefits and Related Measures across the OECD”, OECD Social, Employment and Migration Working Papers, No. 81, OECD Publishing, Paris, http://dx.doi.org/10.1787/225442803245.

Industry Canada (2015), Majority Female-Owned Small and Medium-Sized Enterprises, https://www.ic.gc.ca/eic/site/061.nsf/vwapj/MFOSMEs_KSBS-PMEDMF_PSRPE_201505_eng.pdf/\$FILE/MFOSMEs_KSBS-PMEDMF_PSRPE_2015-05_eng.pdf.

Jaumotte, F. (2004), "Labour Force Participation of Women: Empirical Evidence on The Role of Policy and Other Determinants in OECD Countries", OECD Economic Studies, Vol. 2003/2, http://dx.doi.org/10.1787/eco studies-v2003-art9-en.

Johansson, E. (2010), "The effect of own and spousal parental leave on earnings", No. 2010:4, The Institute for Labour Market Policy Evaluation, Uppsala, https://www.econstor.eu/bitstream/10419/45782/1/623752174.pdf.

Kahn, S. and D. Ginther (2018), "Women and STEM", in Averett, S. and S. Hoffman (eds.), Oxford Handbook on the Economics of Women, Oxford University Press, New York. 
Kis, V. (2016), "Work-based Learning for Youth at Risk: Getting Employers on Board", OECD Education Working Papers, No. 150, OECD Publishing, Paris, http://dx.doi.org/10.1787/5e122a91-en.

Kotsadam, A. and H. Finseraas (2011), "The state intervenes in the battle of the sexes: Causal effects of paternity leave", Social Science Research, Vol. 40, pp. 1611-1622, http://dx.doi.org/10.1016/j.ssresearch.2011.06.011.

Kottelenberg, M. and S. Lehrer (2017), "Targeted or Universal Coverage? Assessing Heterogeneity in the Effects of Universal Child Care", Journal of Labor Economics, Vol. 35/3, pp. 609-653, http://dx.doi.org/10.1086/690652.

Laurin, A., K. Milligan and T. Schirle (2012), Comparing Nest Eggs: How CPP Reform Affects Retirement Choices, CD Howe Institute, Toronto, https://www.cdhowe.org/sites/default/files/attachments/research_papers/mixed/Commentary 352_0.pdf.

Laurin, A. and F. Poschmann (2014), Research: Who Loses Most? The Impact of Taxes and Transfers on Retirement Incomes, CH Howe Institute, Toronto, https://www.cdhowe.org/public-policy-research/who-loses-most-impact-taxes-and-transfersretirement-incomes.

Laurin, I. et al. (2015), Quel est l'effet de la fréuentation d'un service éducatif sur le développement de l'enfant á la materneslle selon le statut socioéconomique?, Agence de la Santé et des Services Sociaux de Montréal, Montreal, https://publications.santemontreal.qc.ca/uploads/tx_asssmpublications/978-2-89673-4757 03.pdf.

Mahboubi, P. (2017), Talkin' 'Bout My Generation: More Educated, But Less Skilled Canadians, CD Howe Institute, https://papers.ssrn.com/sol3/papers.cfm?abstract_id=3073309.

Malatest (2016), Evaluation of the Second Career Program, Prepared for the Ministry of Advanced Education and Skills Development, Toronto, http://www.tcu.gov.on.ca/eng/eopg/publications/sc-evaluation-2016-en.pdf.

Maldonado, L. and R. Nieuwenhuis (2015), "Family policies and single parent poverty in 18 OECD countries, 1978-2008", Community, Work \& Family, Vol. 18/4, pp. 395-415, http://dx.doi.org/10.1080/13668803.2015.1080661.

Mavromaras, K. et al. (2018), Evaluation of the NDIS Final Report, National Institute of Labour Studies, Adelaide, https://www.dss.gov.au/sites/default/files/documents/04 2018/ndis evaluation_consolidated report april 2018.pdf.

MBIE (2017), Māori in the labour market, http://www.mbie.govt.nz/info-services/employmentskills/labour-market-reports/maori-labour-market/maori-in-the-labour-market/maori-dec2016/document-image-library/dashboard-maori-dec-16.pdf. 
McArthur, J. and K. Rasmussen (2017), Who and what gets left behind? Assessing Canada's domestic status on the sustainable development goals, Global Development and Economy at Brookings, Washington DC.

McDonald, J. and R. Thornton (2016), "Have Pay Equity Laws in Canada Helped Women? A Synthetic-Control Approach", American Review of Canadian Studies, Vol. 46/4, pp. 452-473, http://dx.doi.org/10.1080/02722011.2016.1265568.

Messacar, D. (2017), Intra-household Labour Income Responses to Changes in Tax Rates Among Older Workers, Statistics Canada, Ottawa, http://www.statcan.gc.ca/pub/11f0019m/11f0019m2017400-eng.pdf.

Misra, J., M. Budig and I. Boeckmann (2011), "Work-family policies and the effects of children on women's employment hours and wages", Community, Work \& Family, Vol. 14/2, pp. 139157, http://dx.doi.org/10.1080/13668803.2011.571396.

Moore, K., W. Robson and A. Laurin (2010), Will Future Retirees Be Able to Maintain Their Living Standards upon Retirement?, CD Howe Institute, Toronto, https://www.cdhowe.org/sites/default/files/attachments/research_papers/mixed//Commentary 317.pdf.

Morency, J., E. Malenfant and S. MacIsaac (2017), Immigration and diversity: population projections for Canada and its regions, 2011 to 2036, Statistics Canada, Ottawa, http://www.statcan.gc.ca/pub/91-551-x/91-551-x2017001-eng.htm.

Morissette, R. (2018), "Wages up to the age of 40", Statistics Canada Analytical Studies Branch Research Paper Series, Vol. No. 405, http://www.statcan.gc.ca/pub/11f0019m/11f0019m2018405-eng.pdf.

Morissette, R., G. Schellenberg and C. Silver (2004), "Retaining older workers", Perspectives on Labour and Income, Vol. 5/10, https://www.statcan.gc.ca/pub/75-001-x/11004/7366-eng.htm.

Moyser, M. (2017), "Women and Paid Work", in Women in Canada: A Gender-based Statistical Report, Statistics Canada.

Muir, T. (2017), "Measuring social protection for long-term care", OECD Health Working Papers, No. 93, OECD Publishing, Paris, http://dx.doi.org/10.1787/a411500a-en.

Naudeau, S. et al. (2011), Investing in Young Children An Early Childhood Development Guide for Policy Dialogue and Project Preparation, The World Bank, Washington, http://documents.worldbank.org/curated/en/691411468153855017/pdf/578760REPLACEM0 53783B09780821385265.pdf.

Nepomnyaschy, L. and J. Waldfogel (2007), "Paternity leave and fathers' involvement with their young children", Community, Work \& Family, Vol. 10/4, pp. 427-453, http://dx.doi.org/10.1080/13668800701575077.

OECD (2018), Engaging Young Children: Lessons from Research about Quality in Early Childhood Education and Care, OECD Publishing, Paris, http://dx.doi.org/10.1787/9789264085145-en. 
OECD (2018), Gender Governance Review: Canada, Directorate for Public Governance, Paris.

OECD (2018), Gender wage gap (indicator), http://dx.doi.org/10.1787/7cee77aa-en. (accessed on 15 May 2018)

OECD (2017), Basic income as a policy option: Can it add up?, Policy Brief on the Future of Work, Paris, https://www.oecd.org/els/emp/Basic-Income-Policy-Option-2017.pdf.

OECD (2017), Benefits and Wages: Statistics, Directorate for Employment, Labour and Social Affairs, http://www.oecd.org/els/benefits-and-wages-statistics.htm (accessed on 09 November 2017).

OECD (2017), Better Life Index: Canada, http://www.oecdbetterlifeindex.org/countries/canada/ (accessed on 13 December 2017).

OECD (2017), Education at a Glance 2017: OECD Indicators, OECD Publishing, Paris, http://dx.doi.org/10.1787/eag-2017-en.

OECD (2017), Educational Opportunity for All: Overcoming Inequality throughout the Life Course, Educational Research and Innovation, OECD Publishing, Paris, http://dx.doi.org/10.1787/9789264287457-en.

OECD (2017), Employment database - labour market policies and institutions, http://www.oecd.org/employment/emp/employmentdatabaselabourmarketpoliciesandinstitutions.htm (accessed on 05 December 2017).

OECD (2017), Health at a Glance 2017: OECD Indicators, OECD Publishing, Paris, http://dx.doi.org/10.1787/health_glance-2017-en.

OECD (2017), Life expectancy at 65 (indicator), http://dx.doi.org/10.1787/0e9a3f00-en. (accessed on 14 December 2017)

OECD (2017), OECD Employment Outlook 2017, OECD Publishing, Paris, http://dx.doi.org/10.1787/empl outlook-2017-en.

OECD (2017), OECD Family Database, http://www.oecd.org/els/family/database.htm (accessed on 13 November 2017).

OECD (2017), OECD Health Statistics 2017, online database, http://www.oecd.org/els/healthsystems/health-data.htm (accessed on 11 September 2017).

OECD (2017), OECD Labour Force Statistics 2016, OECD Publishing, Paris, http://dx.doi.org/10.1787/oecd 1fs-2016-en.

OECD (2017), Pensions at a Glance 2017: OECD and G20 Indicators, OECD Publishing, Paris, http://dx.doi.org/10.1787/pension_glance-2017-en.

OECD (2017), Preventing Ageing Unequally, OECD Publishing, Paris, http://dx.doi.org/10.1787/9789264279087-en. 
OECD (2017), Promising Practices in Supporting Success for Indigenous Students, OECD

Publishing, Paris, http://dx.doi.org/10.1787/9789264279421-en.

OECD (2017), SME and Entrepreneurship Policy in Canada, OECD Publishing, Paris, http://dx.doi.org/10.1787/9789264273467-en.

OECD (2017), Starting Strong 2017: Key OECD Indicators on Early Childhood Education and Care, OECD Publishing, Paris, http://dx.doi.org/10.1787/9789264276116-en.

OECD (2017), The Pursuit of Gender Equality: An Uphill Battle, OECD Publishing, Paris, http://dx.doi.org/10.1787/9789264281318-en.

OECD (2016), Employment and Skills Strategies in Saskatchewan and the Yukon, Canada, OECD Reviews on Local Job Creation, OECD Publishing, Paris, http://dx.doi.org/10.1787/9789264259225-en.

OECD (2016), Parental leave: Where are the fathers?, Policy Brief, Paris, https://www.oecd.org/policy-briefs/parental-leave-where-are-the-fathers.pdf.

OECD (2016), PISA 2015 Results (Volume I): Excellence and Equity in Education, PISA, OECD Publishing, Paris, http://dx.doi.org/10.1787/9789264266490-en.

OECD (2016), Skills Matter: Further Results from the Survey of Adult Skills, OECD Publishing, Paris.

OECD (2016), The Productivity-Inclusiveness Nexus: Preliminary version, OECD Publishing, Paris, http://dx.doi.org/10.1787/9789264258303-en.

OECD (2015), Back to Work Canada: Improving the re-employment prospects of dIsplaced workers.

OECD (2015), OECD Employment Outlook 2015, OECD Publishing, Paris, http://dx.doi.org/10.1787/empl_outlook-2015-en.

OECD (2015), Pensions at a Glance 2015: OECD and G20 indicators, OECD Publishing, Paris, http://dx.doi.org/10.1787/pension_glance-2015-en.

OECD (2015), Starting Strong IV: Monitoring Quality in Early Childhood Education and Care, OECD Publishing, Paris, http://dx.doi.org/10.1787/9789264233515-en.

OECD (2014), Economic Policy Reforms 2014: Going for Growth Interim Report, OECD Publishing, Paris, http://dx.doi.org/10.1787/growth-2014-en.

OECD (2014), Employment and Skills Strategies in Canada, OECD Reviews on Local Job Creation, OECD Publishing, Paris, http://dx.doi.org/10.1787/9789264209374-en.

OECD (2014), Job Creation and Local Economic Development, OECD Publishing, Paris, http://dx.doi.org/10.1787/9789264215009-en. 
OECD (2014), OECD Economic Surveys: Spain 2014, OECD Publishing, Paris,

http://dx.doi.org/10.1787/eco_surveys-esp-2014-en.

OECD (2014), Report on the OECD framework for inclusive growth, https://www.oecd.org/mcm/IG_MCM_ENG.pdf.

OECD (2014), Society at a Glance 2014: OECD Social Indicators, OECD Publishing, Paris, http://dx.doi.org/10.1787/soc_glance-2014-en.

OECD (2013), OECD Skills Outlook 2013: First Results from the Survey of Adult Skills, OECD Publishing, Paris, http://dx.doi.org/10.1787/9789264204256-en.

OECD (2006), OECD Employment Outlook 2006: Boosting Jobs and Incomes, OECD Publishing, Paris, http://dx.doi.org/10.1787/empl_outlook-2006-en.

OECD (2005), OECD Employment Outlook 2005, OECD Publishing, Paris, http://dx.doi.org/10.1787/empl outlook-2005-en.

OECD (2004), Career Guidance and Public Policy, http://www.oecd.org/edu/innovationeducation/34050171.pdf.

OECD/EU (2016), Inclusive Business Creation: Good Practice Compendium, OECD Publishing, Paris, http://dx.doi.org/10.1787/9789264251496-en.

Office of the Chief Actuary (2017), 14th Actuarial Report on the Old Age Security Program as at 31 December 2015, Office of the Superintendent of Financial Institutions Canada, Ottawa, http://www.osfi-bsif.gc.ca/Eng/Docs/oas14.pdf.

Office of the Chief Actuary (2016), Actuarial Report (13th) supplementing the Actuarial Report on the Old Age Security Program as at 31 December 2012, Office of the Superintendent of Financial Institutions, Ottawa, http://www.osfi-bsif.gc.ca/Eng/oca-bac/ar-ra/oaspsv/Pages/oas13.aspx.

Oreopoulos, P. (2006), "The compelling effects of compulsory schooling: evidence from Canada", Canadian Journal of Economics, Vol. 39/1, pp. 22-52, http://dx.doi.org/10.1111/j.0008-4085.2006.00337.x.

Osborn, R. et al. (2017), "Older Americans Were Sicker And Faced More Financial Barriers To Health Care Than Counterparts In Other Countries", Health Affairs, p. 10.1377/hlthaff, http://dx.doi.org/10.1377/hlthaff.2017.1048.

Ostrovsky, Y. and G. Schellenberg (2010), Pension Coverage and Earnings Replacement Rates Among Canadian Couples, Statistics Canada Analytical Studies Branch Research Paper Series, Ottawa, http://www.statcan.gc.ca/pub/11f0019m/11f0019m2010327-eng.pdf.

Patnaik, A. (2018), "Reserving Time for Daddy: The Short and Long-Run Consequences of Fathers' Quotas", Journal of Labor Economics, forthcoming. 
Petersson, B., M. Rodrigo and K. Ishi (2017), Women Are Key for Future Growth: Evidence from Canada Women Are Key for Future Growth: Evidence from Canada, IMF, Wshington, DC.

Post, C. and K. Byron (2015), "Women on Boards and Firm Financial Performance: A MetaAnalysis", Academy of Management Journal, Vol. 58/5, pp. 1546-1571, http://dx.doi.org/10.5465/amj.2013.0319.

Province of British Columbia (2018), Minimum Wage Increase, https://www2.gov.bc.ca/gov/content/minimum-wage (accessed on 14 February 2018).

Robson, J. (2017), Parental Benefits in Canada: Which Way Forward?, Institute for Research on Public Policy, http://irpp.org/wp-content/uploads/2017/03/study-no63.pdf.

Rønsen, M. and R. Kitterød (2015), "Gender-Equalizing Family Policies and Mothers' Entry into Paid Work: Recent Evidence From Norway”, Feminist Economics, Vol. 21/1, pp. 59-89, http://dx.doi.org/10.1080/13545701.2014.927584.

Sarlo, C. (2017), Understanding Wealth Inequality in Canada, Fraser Institute, Vancouver, https://www.fraserinstitute.org/sites/default/files/understanding-wealth-inequality-incanada.pdf.

Schirle, T. (2015), "The effect of universal child benefits on labour supply", Canadian Journal of Economics/Revue canadienne d'économique, Vol. 48/2, pp. 437-463, http://dx.doi.org/10.1111/caje.12132.

Schirle, T. (2015), "The Gender Wage Gap in the Canadian Provinces, 1997-2014", LCERPA Working Paper No. 2015-6, Laurier Centre for Economic Research and Policy Analysis, Waterloo, ON, http://www.lcerpa.org/public/papers/LCERPA_2015_6.pdf.

Shillington, R. (2016), An Analysis of the Economic Circumstances of Canadian Seniors, [129] Broadbent Institute, Ottawa, http://www.broadbentinstitute.ca/an analysis of the economic circumstances of canadian seniors.

Sonnet, A. et al. (2014), "Towards More Inclusive Ageing and Employment Policies: The Lessons from France, The Netherlands, Norway and Switzerland", De Economist, Vol. 162, pp. 315-339, http://dx.doi.org/10.1007/s10645-014-9240-x.

Statistics Canada (2018), Health-adjusted life expectancy, at birth and at age 65, by sex and income, Canada and provinces, Cansim table 102-0122, http://www5.statcan.gc.ca/cansim/a26?lang=eng\&id=1020122.

Statistics Canada (2018), Life expectancy at various ages, by population group and sex, Canada, Cansim table 109-5401, http://www5.statcan.gc.ca/cansim/a26?lang=eng\&id=1095401.

Statistics Canada (2017), 2016 Census, Data tables, http://www12.statcan.gc.ca/censusrecensement/2016/dp-pd/index-eng.cfm (accessed on 14 December 2017). 
Statistics Canada (2017), Employment Insurance Coverage Survey, 2016, http://www.statcan.gc.ca/daily-quotidien/171215/dq171215b-eng.htm.

Statistics Canada (2017), Labour force survey estimates (LFS), by family type and family age composition, Table 282-0211, http://www5.statcan.gc.ca/cansim/a26?lang=eng\&id=2820211.

Statistics Canada (2017), Social Policy Simulation Database and Model.

Statistics Canada (2016), Employment Insurance Coverage Survey, 2015, https://www.statcan.gc.ca/daily-quotidien/161116/dq161116b-eng.htm.

Steeve, J. et al. (2017), Strength in numbers: Targeting labour force participation to improve prosperity in Ontario, Ontario's Panel on Economic Growth and Prosperity, Toronto, https://www.competeprosper.ca/uploads/Annual_Report 16_Strength_in_numbers targeting labour force participation in Ontario Dec 2017.pdf.

Steiber, N. and B. Haas (2015), "Overworked or Underemployed? Actual and Preferred Household Employment Patterns in the Context of the Economic Crisis", Vienna Institute of Demography, Vienna, http://www.oeaw.ac.at/vid.

Sullivan, O. et al. (2009), "Father-Friendly Policies and Time-Use Data in a Cross-National Context: Potential and Prospects for Future Research", The ANNALS of the American Academy of Political and Social Science, Vol. 624/1, pp. 234-254, http://dx.doi.org/10.1177/0002716209335138.

Sutherland, J. and R. Crump (2011), Exploring alternative level of care (ALC) and the role of funding policies: an evolving evidence base for Canada, Canadian Health Services Research Foundation, Vancouver, http://www.cfhi-fcass.ca/sf-docs/default-source/commissionedresearch-reports/0666-HC-Report-SUTHERLAND final.pdf?sfvrsn=0.

Thévenon, O. and A. Solaz (2013), "Labour Market Effects of Parental Leave Policies in OECD Countries", OECD Social, Employment and Migration Working Papers, No. 141, OECD Publishing, Paris, http://dx.doi.org/10.1787/5k8xb6hw1wjf-en.

Torii, K., S. Fox and D. Cloney (2017), Quality is Key in Early Childhood Education in Australia, Mitchell Institute, Melbourne, http://www.mitchellinstitute.org.au/papers/qualitykey-early-childhood-education-australia/\#.

Tremblay, D. and E. Genin (2010), "Parental leave: from perception to first-hand experience", International Journal of Sociology and Social Policy, Vol. 3010/9, pp. 532-544, http://dx.doi.org/10.1108/01443331011072280.

Turcotte, M. (2014), Canadians with unmet home care needs, Statistics Canada, Ottawa, http://www.statcan.gc.ca/pub/75-006-x/2014001/article/14042-eng.pdf.

Vincent, C. (2013), "Why Do Women Earn Less than Men", CRDCN Research Highlight/RCCDR en évidence, Vol. 1/5, http://ir.lib.uwo.ca/crden recdr/vol1/iss5/1.

Western Economic Diversification Canada (2014), Evaluation of the Women's Enterprise Initiative, https://www.wd-deo.gc.ca/images/cont/18267a-eng.pdf. 
Xie, Y. and K. Shauman (2003), Women in science : career processes and outcomes, Harvard [97] University Press, Cambridge. MA, http://www.hup.harvard.edu/catalog.php?isbn=9780674018594. 